University of South Florida

DIGITAL COMMONS

Digital Commons @ University of

@ UNIVERSITY OF SOUTH FLORIDA

South Florida

KIP Articles

KIP Research Publications

January 1996

\title{
Hydrogeologic Framework of the Edwards-trinity Aquifer System, ^ West-central Texas
}

René A. Barker

Ann F. Ardis

Follow this and additional works at: https://digitalcommons.usf.edu/kip_articles

\section{Recommended Citation}

Barker, René A. and Ardis, Ann F., "Hydrogeologic Framework of the Edwards-trinity Aquifer System, ^ West-central Texas" (1996). KIP Articles. 2510.

https://digitalcommons.usf.edu/kip_articles/2510

This Article is brought to you for free and open access by the KIP Research Publications at Digital Commons @ University of South Florida. It has been accepted for inclusion in KIP Articles by an authorized administrator of Digital Commons @ University of South Florida. For more information, please contact digitalcommons@usf.edu. 


\section{HYDROGEOLOGIC FRAMEWORK OF THE EDWARDS-TRINITY AQUIFER SYSTEM, WEST-CENTRAL TEXAS}

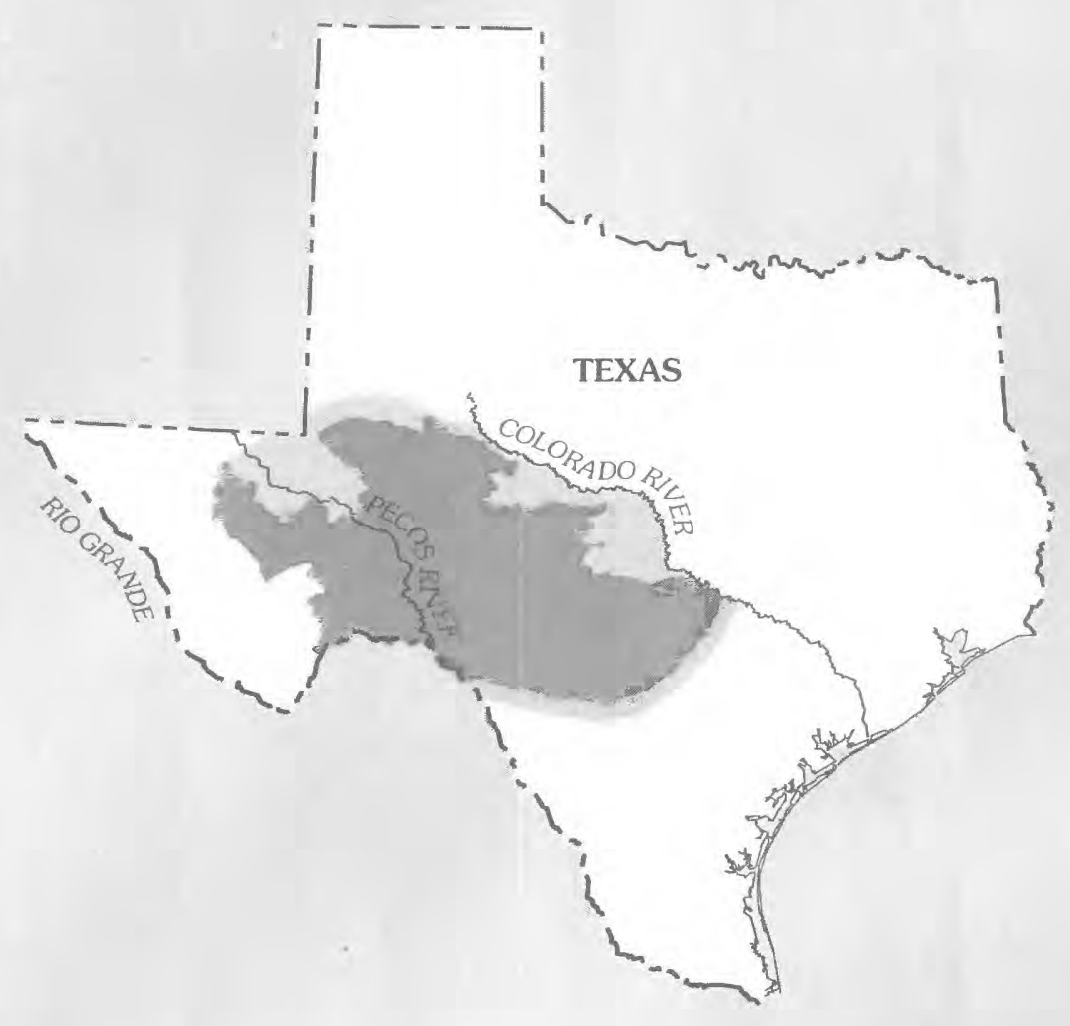




\section{Availability of Books and Maps of the U.S. Geological Survey}

Instructions on ordering publications of the U.S. Geological Survey, along with prices of the last offerings, are given in the currentyear issues of the monthly catalog "New Publications of the U.S. Geological Survey." Prices of available U.S. Geological Survey publications released prior to the current year are listed in the most recent annual "Price and Availability List." Publications that may be listed in various U.S. Geological Survey catalogs (see back inside cover) but not listed in the most recent annual "Price and Availability List" may be no longer available.

\section{BY MAIL}

\section{Books}

Professional Papers, Bulletins, Water-Supply Papers, Techniques of Water-Resources Investigations, Circulars, publications of general interest (such as leaflets, pamphlets, booklets), single copies of Earthquakes \& Volcanoes, Preliminary Determination of Epicenters, and some miscellaneous reports, including some of the foregoing series that have gone out of print at the Superintendent of Documents, are obtainable by mail from

\section{U.S. Geological Survey, Information Services}

Box 25286, Federal Center, Denver, CO 80225

Subscriptions to periodicals (Earthquakes \& Volcanoes and Preliminary Determination of Epicenters) can be obtained ONLY from the

\section{Superintendent of Documents \\ Government Printing Office \\ Washington, DC 20402}

(Check or money order must be payable to Superintendent of Documents.)

\section{Maps}

For maps, address mail orders to

U.S. Geological Survey, Information Services Box 25286, Federal Center, Denver, CO 80225

\section{OVER THE COUNTER}

\section{Books and Maps}

Books and maps of the U.S. Geological Survey are available over the counter at the following U.S. Geological Survey Earth Science Information Centers (ESID), all of which are authorized agents of the Superintendent of Documents:

- ANCHORAGE, Alaska-Rm. 101, 4230 University Dr.

- LAKEWOOD, Colorado-Federal Center, Bldg. 810

- MENLO PARK, California-BIdg. 3, Rm. 3128, 345 Middlefield Rd.

- RESTON, Virginia--USGS National Center, Rm. 1C402, 12201 Sunrise Valley Dr.

- SALT LAKE CITY, Utah-Federal Bldg., Rm. 8105, 125 South State St.

- SPOKANE, Washington-U.S. Post Office Bldg., Rm. 135, West 904 Riverside Ave.

- WASHINGTON, D.C.-Main Interior BIdg., Rm. 2650, 18th and C Sts., NW.

\section{Maps Only}

Maps may be purchased over the counter at the following U.S. Geological Survey offices:

- ROLLA, Missouri-1400 Independence Rd.

- STENNIS SPACE CENTER, Mississippi-Bldg. 3101 


\title{
Hydrogeologic Framework of the Edwards-Trinity Aquifer System, West-Gentral Texas
}

\author{
By RENÉ A. BARKER and ANN F. ARDIS
}

REGIONAL AQUIFER-SYSTEM ANALYSIS-

EDWARDS-TRINITY AQUIFER SYSTEM

U.S. GEOLOGICAL SURVEY PROFESSIONAL PAPER $1421-$ B 


\title{
U.S. DEPARTMENT OF THE INTERIOR BRUCE BABBITT, Secretary
}

\author{
U.S. GEOLOGICAL SURVEY
}

Gordon P. Eaton, Director

\begin{abstract}
The use of firm, trade, and brand names in this report is for identification purposes only and does not constitute endorsement by the U.S. Government.
\end{abstract}

\section{Library of Congress Cataloging in Publications Data}

Barker, René A.

Hydrogeologic framework of the Edwards-Trinity aquifer system, west-central Texas / by René A. Barker and Ann F. Ardis.

p. cm. - (Regional aquifer-system analysis-Edwards-Trinity aquifer system) (U.S. Geological Survey professional paper; 1421-B)

Includes bibliographical references (p. J40-J41).

Supt. of Docs. no.: I 19.16:P1421-B

1. Edwards Aquifer (Tex.) 2. Trinity Aquifer (Tex.) I. Ardis, Ann F. II. Title. III. Series: Regional aquifer-system analysis-Edwards-Trinity aquifer system ; B. IV. Series: U.S. Geological Survey professional paper ; 1421. GB1199.3.T4B37 1996

$551.49^{\prime} 09764-\mathrm{dc} 20$

For sale by U.S. Geological Survey

Branch of Information Services, Box 25286

Federal Center, Denver, CO 80225 


\section{FOREWORD}

\section{THE REGIONAL AQUIFER-SYSTEM ANALYSIS PROGRAM}

The Regional Aquifer-System Analysis (RASA) Program represents a systematic effort to study a number of the Nation's most important aquifer systems, which, in aggregate, underlie much of the country and which represent an important component of the Nation's total water supply. In general, the boundaries of these studies are identified by the hydrologic extent of each system and, accordingly, transcend the political subdivisions to which investigations have often arbitrarily been limited in the past. The broad objective for each study is to assemble geologic, hydrologic, and geochemical information; to analyze and develop an understanding of the system; and to develop predictive capabilities that will contribute to the effective management of the system. The use of computer simulation is an important element of the RASA studies to develop an understanding of the natural, undisturbed hydrologic system and the changes brought about in it by human activities and to provide a means of predicting the regional effects of future pumping or other stresses.

The final interpretive results of the RASA Program are presented in a series of U.S. Geological Survey Professional Papers that describe the geology, hydrology, and geochemistry of each regional aquifer system. Each study within the RASA Program is assigned a single Professional Paper number beginning with Professional Paper 1400.

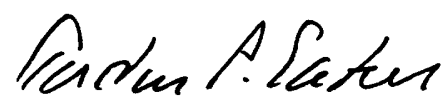

Gordon P. Eaton Director 



\section{CONTENTS}

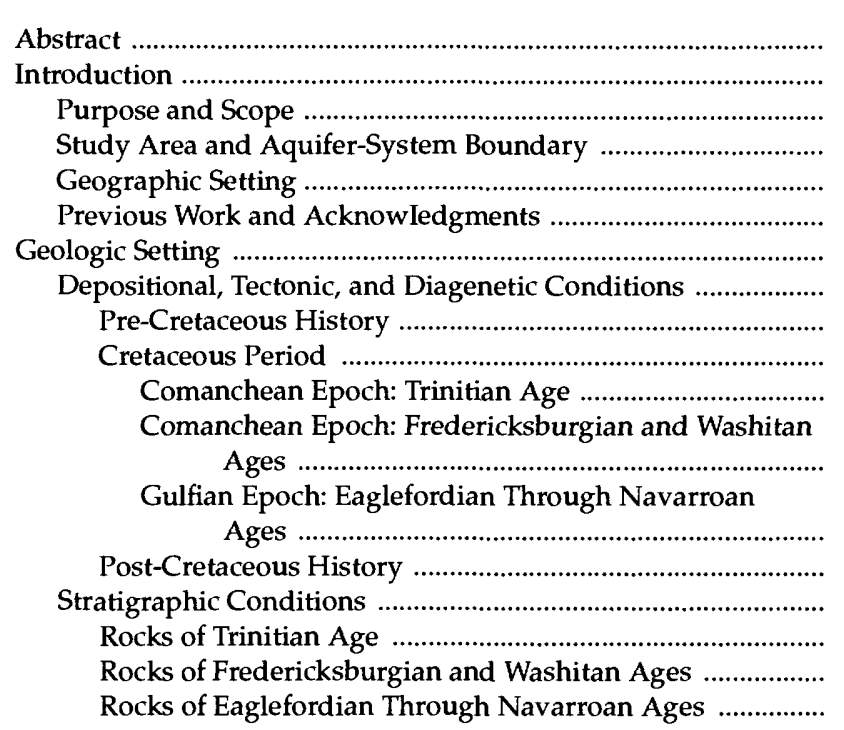

\begin{tabular}{|c|c|}
\hline Bage & Aquiter System \\
\hline 2 & rinity Aquirer system \\
\hline 2 & 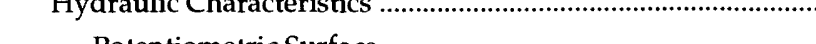 \\
\hline 2 & Potentiometric Surface .......................... \\
\hline 5 & Saturated Thickness .. \\
\hline 10 & Transmissivity ......................... \\
\hline 11 & 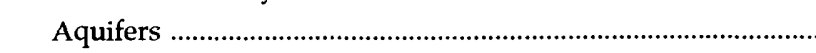 \\
\hline 12 & 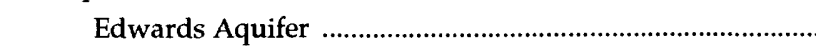 \\
\hline 13 & Trinity Aquifer ........... \\
\hline 13 & 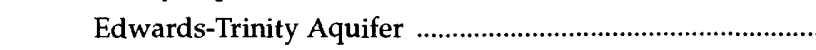 \\
\hline 17 & Edwards Plateau \\
\hline & Trans-Pecos \\
\hline 24 & Confining Units \\
\hline 24 & Navarro-Del Rio Confining Unit \\
\hline $\begin{array}{l}29 \\
30\end{array}$ & 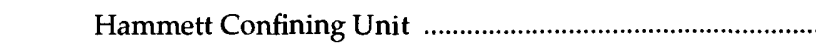 \\
\hline 33 & 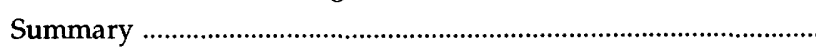 \\
\hline 24 & ected References \\
\hline
\end{tabular}

\section{PLATES}

[Plates are in pocket]

PLATE 1. Correlation chart showing the chronostratigraphic, lithostratigraphic, and regional hydrogeologic units in the EdwardsTrinity aquifer system, west-central Texas

2-8. Hydrogeologic sections:

2. $A-A^{\prime}$ from Culberson County to Kinney County, Texas

3. $B-B^{\prime}$ from Andrews County to Bexar County, Texas

4. $C-C^{\prime}$ from Winkler County to Coke County, Texas

5. D-D' from Brewster County to Howard County, Texas

6. E-E' from Tom Green County to Kinney County, Texas

7. $F-F^{\prime}$ from Concho County to Uvalde County, Texas

8. $G-G^{\prime}$ from Kendall County to Travis County, Texas

\section{ILLUSTRATIONS}

FIGURES 1-4. Maps showing location of the:

1. Study area of the Edwards-Trinity Regional Aquifer-System Analysis

2. Aquifers and confining units in the Edwards-Trinity aquifer system and of contiguous major aquifers in west-central Texas

3. Geographic subareas of the Edwards-Trinity aquifer system and the major springs and perennial streams

4. Outcrop and shallow subcrop of rocks in the area of the Edwards-Trinity aquifer system .. 
5. Diagrammatic section showing generalized relation between the Edwards-Trinity aquifer system and the pre-Cretaceous rocks and hydrogeologic units that form the base of the system

6-8. Maps showing:

6. Paleogeographic and structural features in west-central Texas and parts of adjacent States and northern Mexico

7. Chronology and configuration of the rocks that form the base of the Edwards-Trinity aquifer system and selected contiguous hydraulically connected units

8. Lateral distribution of Trinity rock units in west-central Texas

9-10. Diagrammatic sections showing:

9. Vertical distribution of Trinity rock units in west-central Texas and their relation to geographic subareas

10. Structural controls on the deposition of Fredericksburg and Washita strata of the Edwards-Trinity aquifer system

11. Map showing lateral distribution of Fredericksburg and lower Washita rock units in west-central Texas

12. Schematic sections showing vertical distribution of Fredericksburg and lower Washita rock units in west-central Texas, and their relation to depositional environments

13. Map showing general distribution of the prevailing depositional environments during Fredericksburgian through early Washitan time in west-central Texas, and the resulting rock types

14. Schematic diagram showing progression of major depositional, tectonic, and diagenetic events affecting development of the Edwards-Trinity aquifer system

15-22. Maps showing:

15. Orientation of hydrogeologic sections and location of wells used for control

16. Historical (1915-69) potentiometric surface of the Edwards-Trinity aquifer system and of selected contiguous hydraulically connected units

17. Historical (1915-69) distribution of saturated thickness in the Edwards-Trinity aquifer system and in selected contiguous hydraulically connected units

18. Regional distribution of transmissivity in the Edwards-Trinity aquifer system and in selected contiguous hydraulically connected units

19. Thickness of the middle Trinity permeable zone in the Trinity aquifer of the Edwards-Trinity aquifer system

20. Thickness of the lower Trinity permeable zone in the Trinity aquifer of the Edwards-Trinity aquifer system .

21. Thickness of the Hammett confining unit in the Edwards-Trinity aquifer system ...

22. Configuration of the top of Trinity strata and base of Fredericksburg strata in west-central Texas

\section{TABLES}

TABLE 1. Carbonate-rock classification systems adapted from Dunham (1962) and Folk (1962)

2. Approximate maximum thickness of lithostratigraphic units that compose the Edwards-Trinity aquifer system, west-central Texas 
CONTENTS

\section{CONVERSION FACTORS, VERTICAL DATUM, AND ABBREVIATED WATER-QUALITY UNIT}

\begin{tabular}{rll}
\hline Multiply & \multicolumn{1}{c}{ By } & To obtain \\
\hline acre-foot (acre-ft) & 0.001233 & cubic hectometer \\
acre-foot per year (acre- $\mathrm{ft} / \mathrm{yr})$ & 0.001233 & cubic hectometer per year \\
cubic foot per second $\left(\mathrm{ft}^{3} / \mathrm{s}\right)$ & 0.02832 & cubic meter per second \\
foot $(\mathrm{ft})$ & 0.3048 & meter \\
foot per day $(\mathrm{ft} / \mathrm{d})$ & 0.3048 & meter per day \\
foot per mile $(\mathrm{ft} / \mathrm{mi})$ & 0.1894 & meter per kilometer \\
foot squared per day $\left(\mathrm{ft}^{2} / \mathrm{d}\right)$ & 0.0929 & meter squared per day \\
gallon per minute $(\mathrm{gal} / \mathrm{min})$ & 0.06309 & liter per second \\
inch $(\mathrm{in})$. & 25.4 & millimeter \\
inch per year (in/yr) & 25.4 & millimeter per year \\
mile $(\mathrm{mi})$ & 1.609 & kilometer \\
square mile $\left(\mathrm{mi}{ }^{2}\right)$ & 2.590 & square kilometer \\
\hline
\end{tabular}

Sea level: In this report, "sea level" refers to the National Geodetic Vertical Datum of 1929-a geodetic datum derived from a general adjustment of the first-order level nets of both the United States and Canada, formerly called Sea Level Datum of 1929.

Abbreviated water-quality unit:

$\mathrm{mg} / \mathrm{L}$, milligram per liter 



\title{
REGIONAL AQUIFER-SYSTEM ANALYSIS-EDWARDS-TRINITY AQUIFER SYSTEM
}

\section{HYDROGEOLOGIC FRAMEWORK OF THE EDWARDS-TRINITY AQUIFER SYSTEM, WEST-CENTRAL TEXAS}

\author{
BY RENÉ A. BARKER AND ANN F. ARDIS
}

\section{ABSTRACT}

The Edwards-Trinity aquifer system underlies about 42,000 square miles of west-central Texas. Nearly flat-lying Comanche (mostly Lower Cretaceous) and Gulf (Upper Cretaceous) strata of the aquifer system thin northwestward atop generally massive pre-Cretaceous rocks that are comparatively impermeable and structurally complex. From predominately terrigenous clastic sediments in the east and terrestrial deposits in the west, the rocks of early Trinitian (Comanchean) age grade upward into supratidal and intertidal evaporitic and dolomitic rocks and shallow-marine, lagoonal, and basinal carbonate strata of late Trinitian, Fredericksburgian, and Washitan (Comanchean) age. A thick, downfaulted remnant of mostly open-shelf sediments of Eaglefordian through Navarroan (Gulfian) age confines a small, southeastern part of the aquifer system.

While clastic deposition prevailed upon alluvial plains inland of a westward-advancing Cretaceous sea, offshore environments were dominated by the biogenic accumulation of calcium carbonate in warm, generally clear seawater. The Trinity strata were deposited as the sea encroached upon the Llano uplift, the most prominent feature on a rolling peneplain composed of folded and faulted pre-Cretaceous rocks. The Fredericksburg and Washita strata mostly formed above the Llano uplift, on a carbonate platform sheltered from storm waves and deep ocean currents by the Stuart City reef trend. Subsequently, the entire study area was blanketed with mostly argillaceous sediments of the Eagle Ford, Austin, Taylor, and Navarro Groups.

During late Oligocene through early Miocene time, large-scale normal faulting formed the Balcones fault zone, where the Cretaceous strata were displaced vertically, fractured intensively, and rotated differentially within a series of southwest-to-northeast trending fault blocks. Ground-water flow shifted toward the northeast in response to rejuvenated hydraulic gradients and high-angle barrier faults that blocked southeastward flow. Subsurface conduits lengthened in a southwest-to-northeast direction as evaporites and soluble calcareous constituents (other carbonate minerals and allochems) dissolved from the fractured strata and discharged to downgradient springs and streams. The springs originated in topographically low areas where confined ground water was diverted to the surface by barrier faults. Ground-water conduits enlarged through carbonate dissolution along flowpaths that converged toward the springs. The major springs persisted to control modern potentiometric levels and discharge patterns. Stream erosion eventually breached the overlying, low-permeability
Gulf rocks and provided discharge areas for aquifers in the underlying more permeable Comanche rocks.

The Balcones faulting triggered processes responsible for sizable contrasts between the hydraulic characteristics of Cretaceous strata in the Balcones fault zone and those elsewhere in the Edwards-Trinity aquifer system. By vertically displacing the terrain, the faulting increased hydraulic gradients, which enhanced the percolation of meteoric (precipitation-derived) water from land surface and increased the velocity of ground-water flow. A dynamic regime of shallow ground-water flow evolved that promoted dissolution and enhanced the transmissivity of the Edwards Group in the Balcones fault zone. Cementation, recrystallization, and replacement resulting from deep burial and comparatively sluggish ground-water movement combined to diminish the transmissivity of the underlying Trinity strata, as well as most Cretaceous strata in the Hill Country, Edwards Plateau, and Trans-Pecos.

The Cretaceous strata comprise a regional aquifer system of three aquifers and two confining units. The aquifers are the Edwards aquifer in the Balcones fault zone, the Trinity aquifer in the Hill Country and deeper parts of the Balcones fault zone, and the Edwards-Trinity aquifer in the Edwards Plateau and Trans-Pecos. The Navarro-Del Rio confining unit confines downdip parts of the Edwards aquifer in the Balcones fault zone. The Hammett confining unit, composed of the Hammett Shale, confines basal parts of the Trinity and Edwards-Trinity aquifers in most of the Hill Country and in a small southeastern part of the Edwards Plateau. The confining units mostly are composed of calcareous mudstone, siltstone, and shale deposited in low-energy terrigenous and open-shelf marine environments. The permeable strata mainly result from fractures and joint cavities, solution channels, and fabric-selective forms of porosity caused by the dissolution of evaporites and soluble calcareous constituents. Transmissivity in the Edwards-Trinity aquifer system ranges from less than 5,000 to more than $5,000,000$ feet squared per day. Although transmissivity probably averages about 750,000 feet squared per day in the Edwards aquifer, it probably averages less than 10,000 feet squared per day elsewhere in the aquifer system. Outside the Balcones fault zone, where the hydraulic conductivity typically is small, transmissivity generally is greater than 5,000 feet squared per day where the saturated thickness of the aquifer exceeds 500 feet and generally is less than 5,000 feet squared per day where saturated thickness is less than 500 feet. 


\section{INTRODUGTION}

The Edwards-Trinity aquifer system, underlying about $42,000 \mathrm{mi}^{2}$ of west-central Texas, was studied as a part of the Regional Aquifer-System Analysis (RASA) program of the U.S. Geological Survey. The U.S. Geological Survey began the RASA program during 1978 to improve the hydrogeologic information on the major aquifer systems in the Nation. The Edwards-Trinity RASA was one of 28 projects identified for study (Weeks and Sun, 1987). Key objectives of each RASA study were to (1) delineate the regional aquifers and regional confining units in the study area, (2) evaluate the effects of the geology on the ground-water-flow system, and (3) integrate the results of previous hydrogeologic investigations in the study area.

\section{PURPOSE AND SCOPE}

This report describes the hydrogeologic framework of the Edwards-Trinity aquifer system. The depositional, tectonic, diagenetic, and stratigraphic conditions of the rocks that compose the aquifer system are described under "Geologic Setting." The hydraulic characteristics, aquifers, and confining units are described under "Edwards-Trinity Aquifer System." A correlation chart (pl. 1) and seven hydrogeologic sections (pls. 2-8) illustrate the relations between the chronostratigraphic and lithostratigraphic units and the aquifers and confining units in the study area.

\section{STUDY AREA AND AQUIFER-SYSTEM BOUNDARY}

The RASA study area (fig. 1) extends in places beyond the Edwards-Trinity aquifer system to include contiguous terrain that is connected hydraulically to the aquifer system. The boundary of the aquifer system coincides in most places with the outer edge of Cretaceous rocks that are the principal source of ground water. Contiguous hydraulically connected rocks lie between the Edwards-Trinity aquifer system and the limits of regional ground-water flow.

The Edwards-Trinity aquifer system comprises three regional aquifers and two regional confining units (fig. 2). From east to west, the aquifers are the Edwards aquifer, Trinity aquifer, and Edwards-Trinity aquifer. The aquifers are laterally adjacent except in the southeastern part of the system, where a downfaulted part of the Trinity aquifer is overlain by the Edwards aquifer. The Navarro-Del Rio confining unit confines downdip parts of the Edwards aquifer, and the Hammett confining unit confines basal parts of the Trinity and Edwards-Trinity aquifers.
With the exception of the High Plains aquifer (defined by Weeks and others, 1988), the aquifer nomenclature used in this report was adopted from that recommended in the recently amended Texas Water Plan (Texas Water Development Board, 1990, p. 1-5 and 1-6).

The boundary of the Edwards-Trinity aquifer system between west-central Travis County and eastern Brewster County mostly is defined by geologic conditions. From west-central Travis County to north-central Glasscock County, the boundary coincides approximately with the updip limit of the Cretaceous rock outcrop (University of Texas, Bureau of Economic Geology, 1974b; 1975; 1976a, c; 1981a; Ashworth and Flores, 1991, fig. 1). This segment of the boundary is characterized in places by a low escarpment facing away from the aquifer system. From north-central Glasscock County to northwestern Ector County, the boundary coincides approximately with the updip limit of the Cretaceous rock subcrop. This segment is defined approximately because the basal Cretaceous sand at the base of the Edwards-Trinity aquifer (Mount and others, 1967, p. 45) is virtually indistinguishable from the Ogallala Formation, which forms the High Plains aquifer in that area (Weeks and others, 1988). From northwestern Ector County to Culberson County, the boundary is where Cretaceous rocks abut the Cenozoic Pecos alluvium of Cenozoic age (University of Texas, Bureau of Economic Geology, 1976b; Rees and Buckner, 1980, fig. 2). From Culberson County to the Rio Grande in Brewster County, the boundary traverses the eastern flanks of several mountain ranges where the Cretaceous rocks pinch out, are structurally detached, or mostly are impermeable (Rees and Buckner, 1980, fig. 2).

The boundary of the Edwards-Trinity aquifer system between eastern Brewster County and west-central Travis County mostly is defined by hydrologic conditions. Because potentiometric data indicate that the Rio Grande is a regional ground-water drain (Bush and others, 1993), the boundary of the aquifer system is assumed to coincide with the Rio Grande from eastern Brewster County to south-central Val Verde County. From the Rio Grande in south-central Val Verde County to the Colorado River in central Travis County, the aquifer system is bounded by a narrow transition zone between freshwater and saline water (fig. 2) that minimizes the downdip flow of freshwater from the Edwards aquifer. The aquifer system boundary coincides with the updip edge of the transition zone, which is defined by the $1,000-\mathrm{mg} / \mathrm{L}$ line of equal dissolved-solids concentration as modified from Maclay and others (1980, fig. 7). Although dissolved-solids data for the Trinity aquifer are too sparse to define lines of equal dissolved-solids concentration, the 


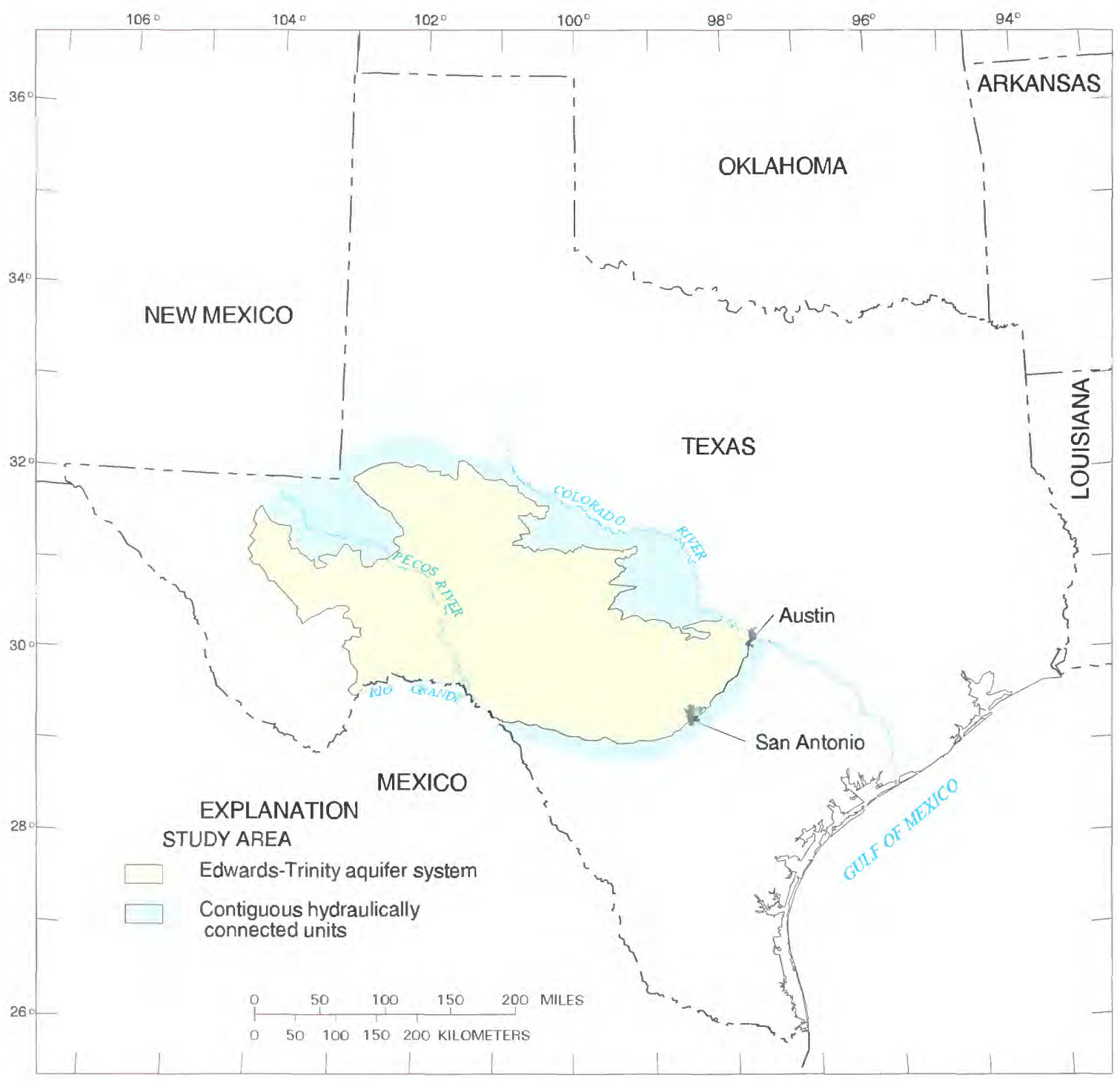

FIGURE 1.-Location of the study area of the Edwards-Trinity Regional Aquifer-System Analysis.

freshwater/saline-water transition zone extends updip and presumably underlies the Trinity aquifer. Limited data indicate that the transition zone in the Trinity aquifer is steep enough to approximate the position, in plane view, of the transition zone in the Edwards aquifer (Duffin, 1974, fig. 18; Brune and Duffin, 1983, fig. 12).

The Colorado River bounds the Edwards-Trinity aquifer system through west-central Travis County. Although Cretaceous rocks extend north of the river, potentiometric data (Baker and others, 1986, fig. 20) indicate that ground-water flow is truncated at this deeply entrenched, regional drain.

The study area (fig. 1) was extended beyond the boundary of the Edwards-Trinity aquifer system to account for the hydraulic connection with contiguous rock units around the southeastern, northeastern, and northwestern edges of the system. The southeastern limit of the study area was drawn arbitrarily to coincide with the estimated location of the $10,000-\mathrm{mg} / \mathrm{L}$ line of equal dissolved-solids concentration, which was based on data from Maclay and others (1980, p. 13). The study area is delimited on the northeast by the Colorado River, a regional discharge boundary (Kuniansky, 1990) for aquifers in the contiguous pre-Cretaceous rocks that underlie the river (Mount and others,'1967, pl. 4). The northwestern part of the study area includes much of the Cenozoic Pecos alluvium aquifer (Texas Water Development Board, 1990, fig. 1-1) and a small part of the High Plains aquifer (Weeks and others, 1988, fig. 1). 


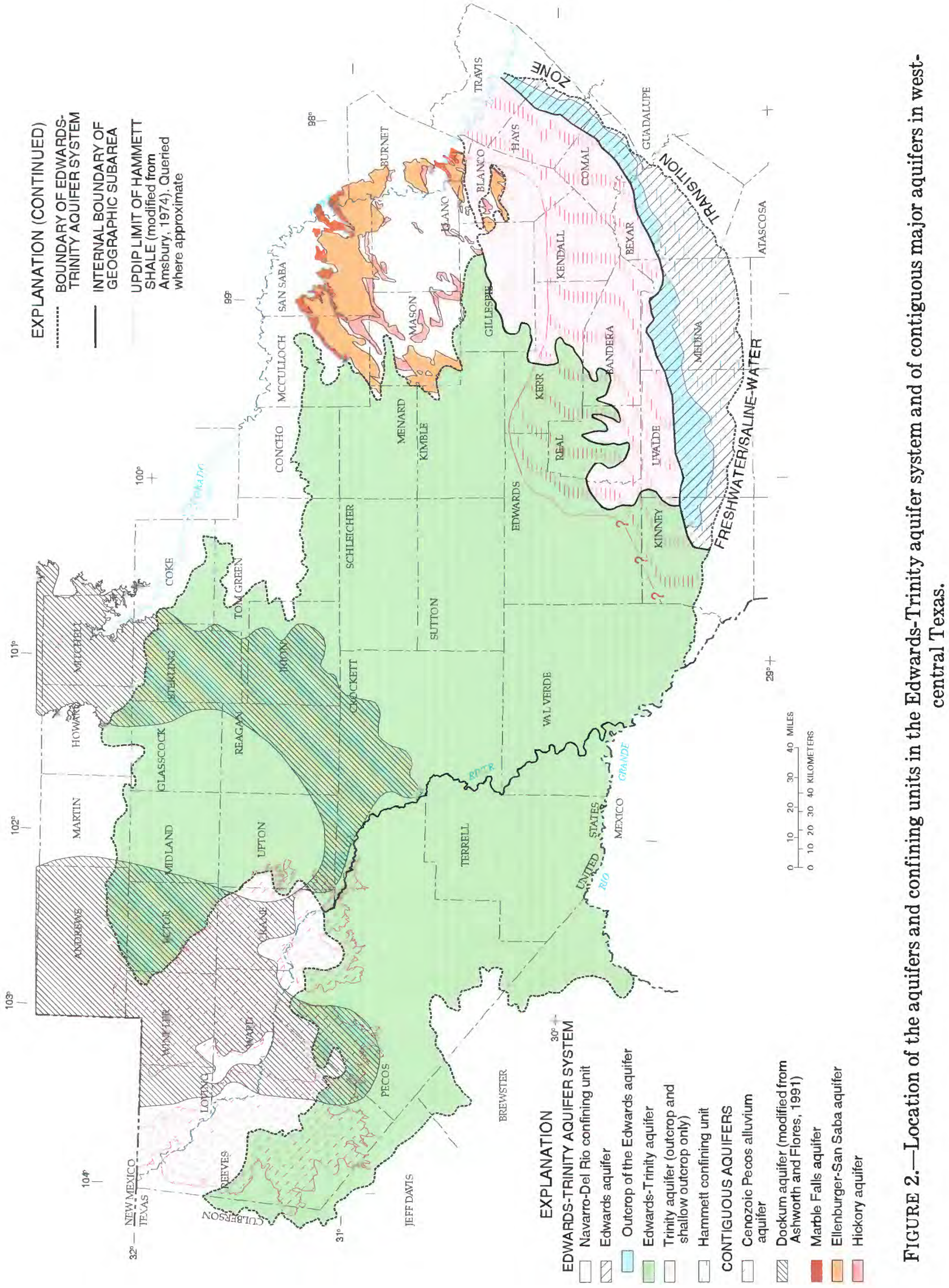


The Edwards-Tr nity aquifer system is overlain locally by the Del Rio Clay or Buda Limestone. Together, these rela ively impermeable units comprise the lower 10 to 20 percent of the Navarro-Del Rio confining unit (fig. 2), which overlies the Edwards aquifer in the southeastern part of the study area. The base of the Edwards-Trinity aquifer system is formed of Paleozoic and Trias:ic rocks that mostly are impermeable (Barker and Ardis, 1992). Where adjacent Paleozoic and Triassic rocks are permeable, they form contiguous hydraulically connected units (fig. 1).

\section{GEOGRAPHIC SETTING}

The Edwards-Trinity aquifer system was divided into four geographic subareas (fig. 3), each of which is characterized by distinct physiographic, hydrologic, and geologic patterns. From largest to smallest, the subareas are the Edwards Plateau $\left(24,000 \mathrm{mi}^{2}\right)$; the TransPecos $\left(9,700 \mathrm{mi}^{2}\right)$; the Hill Country $\left(5,300 \mathrm{mi}^{2}\right)$; and the Balcones fault zone south of the Colorado River $(3,000$ $\mathrm{mi}^{2}$ ). (The Balcones fault zone south of the Colorado River is hereinafter referred to as Balcones fault zone.) The Edwards-Trinity aquifer extends throughout the Edwards Plateau and Trans-Pecos. The Trinity aquifer is the principal aquifer in the Hill Country, and the Edwards aquifer is the principal aquifer in the Balcones fault zone.

The Edwards Plateau (fig. 3 ) is a resistant carbonaterock upland veneered with loose, thin soils atop nearly flat-lying limestone and dolostone. Caprock mesas, broad alluvial fans, and dry arroyos punctuate an otherwise nearly featureless plain. The topographic contours in figure 3 indicate a gradual northwest-to-southeast slope on the land surface, from altitudes of about 3,000 to $2,000 \mathrm{ft}$ above sea level, and a steeper north-to-south gradient, from about 2,000 to $1,000 \mathrm{ft}$ above sea level.

In contrast to interior parts of the Edwards Plateau, the eastern and southern margins of the Plateau are topographically rugged where high-velocity headwaters have cut narrow, steep-walled canyons into the carbonate terrain. Watercourses that are intermittent in the higher elevations of the Edwards Plateau evolve downstream into perennial streams, as their channels intersect the water table and gain base flow in the Hill Country (Kuniansky, 1989).

Most carbonate strata in the eastern part of the Edwards Plateau are Fredericksburg and Washita rocks that in the past were known collectively as "Edwards and associated limestones." Rose (1972) included these strata in the Edwards Group (pl. 1). The Edwards Group and its equivalents in the Trans-Pecos and western part of the Edwards Plateau are connected hydraulically to the underlying terrigenous clastic and carbonate sediments of Trinitian age. Thus, the name Edwards-Trinity aquifer was given to all Lower Cretaceous rocks in the Edwards Plateau and Trans-Pecos that, for the most part, are hydraulically continuous (Texas Water Development Board, 1990, fig. 1-1).

The Trans-Pecos lies west of the Pecos River (fig. 3). Southeast of Fort Stockton, in the Stockton Plateau (Fenneman, 1931, p. 47), the Trans-Pecos is an extension of the Edwards Plateau. Northwest of Fort Stockton, the Trans-Pecos occupies much of what Fenneman (1931, p. 48) called the Toyah basin, which is the southernmost part of the trough-like, alluvial-filled valley of the Pecos River. The Toyah basin is topographically flatter than the Stockton Plateau and is covered with alluvium that ranges in thickness from a few feet near the broad escarpment of the Stockton Plateau to several hundred feet near the northern limit of Cretaceous rocks. Thus, the Edwards-Trinity aquifer is exposed or only thinly covered in the southern part of the Trans-Pecos, and it is partly buried under a mantle of alluvial sediments of varying thickness in the northern part.

Land-surface altitudes in the Trans-Pecos decrease from nearly $5,000 \mathrm{ft}$ in the foothills of mountains that bound the aquifer system on the west to about $1,100 \mathrm{ft}$ near the confluence of the Pecos River and Rio Grande. The Pecos River and Rio Grande are the only perennial streams in the Trans-Pecos. Between the mountain front and the Pecos River, the land surface is characterized by intermittently flowing streams. From well-defined valleys in the western foothills, the intermittent streams descend onto gently sloping lowlands. The stream channels broaden into shallow arroyos as they leave the foothills and enter the alluvial-filled Toyah basin and nearly disappear as they approach the Pecos River (Armstrong and McMillion, 1961, p. 13-14). Valleys in the Stockton Plateau generally are defined most clearly where they cut through dense carbonate rock. Along the eastern and southern boundary of the Stockton Plateau, the Pecos River and Rio Grande flow through deep, narrow canyons with cliff-forming walls of massive limestone.

The streams originating along the southeastern margin of the Edwards Plateau and their downstream tributaries are largely responsible for the high topographic relief of the Hill Country (fig. 3). Headward erosion by southeast-flowing streams has stripped all but a few thin remnants of the Edwards Group and its stratigraphic equivalents from the Hill Country, exposing Trinity rocks at land surface; thus, "Trinity" was adopted for the name of the principal aquifer in the Hill Country (Texas Water Development Board, 1990, fig. 1-1). The Trinity aquifer is an extension of the lower part of the Edwards-Trinity aquifer of the Edwards 


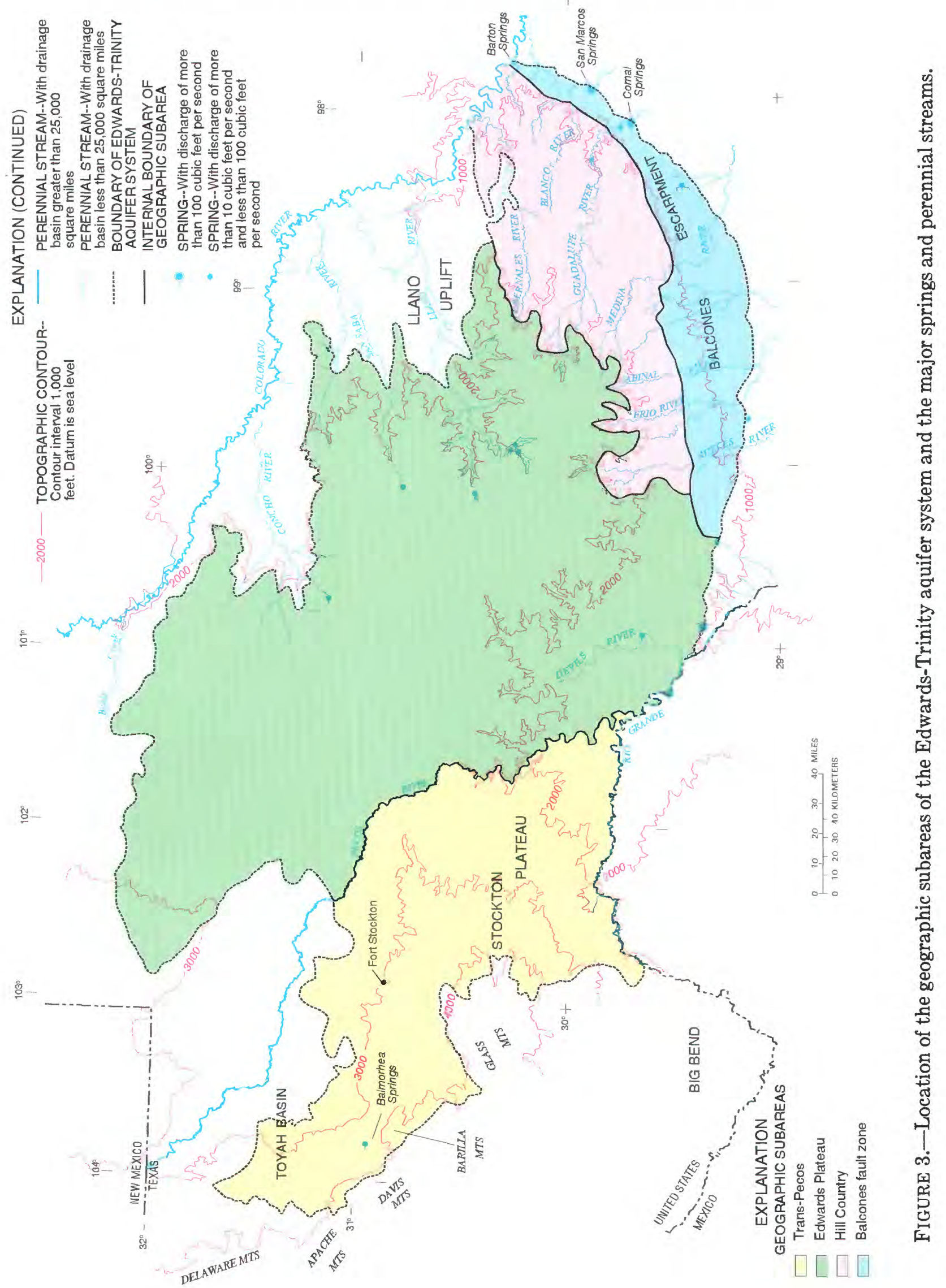


Plateau; the hydraulic properties of the two are similar, but the Edwards Group and its equivalents mostly are absent in the Hill Country. The boundary between the Edwards Plateau and the Hill Country was delineated from the outcrop configuration of the Trinity rocks (University of Texas, Bureau of Economic Geology, 1977; 1981a; 1983).

The major streams descend relatively steep gradients as they cut through the Hill Country. Many upgradient reaches are contained within deep, narrow canyons characterized by nearly vertical walls. Although most canyons broaden downstream into relatively flatbottomed valleys, they typically retain nearly vertical walls. Attributing the widening of the steep-walled canyons to a condition known as "spring sapping," Fenneman (1931, p. 53) stated that the effect of spring discharge in the area was "*** to sap the strong rocks of the canyon walls which thereupon retreat and separate."

The Balcones fault zone, lying south and east of the Hill Country (fig. 3), is defined by an en echelon network of mostly down-to-the-southeast normal faults (fig. 4). The faults are most abundant across northern Medina, central Bexar, southern Comal, southern Hays, and central Travis Counties (Baker and others, 1986, fig. 2; Maclay and Small, 1986, fig. 3). These faults are the principal structural features of the study area, and they greatly influence the rate and direction of groundwater flow.

The gradual southeastward dip of the Cretaceous rocks in the Trans-Pecos, Edwards Plateau, and Hill Country is interrupted in the Balcones fault zone. Because of post-depositional subsidence and vertical displacement, the rocks in the Balcones fault zone dip more steeply than those elsewhere in the study area.

The Edwards Group, of Fredericksburgian and early Washitan ages, contains the most transmissive rocks in the study area and composes most of the Edwards aquifer in the Balcones fault zone. The rocks of Trinitian age, which are relatively impermeable and deeply buried in the fault zone, contribute little to the transmissivity of the fault zone.

The boundary between the Hill Country and the Balcones fault zone separates the area where the Trinity aquifer is the principal source of ground water from the area where the Edwards aquifer is the principal source. The boundary connects the updip edge of major faults that juxtapose rocks of Trinitian age on the west against the Edwards Group (or the stratigraphic equivalents of the Edwards Group) on the east. This delineation was based on fault locations mapped by the University of Texas, Bureau of Economic Geology (1974a; 1977; 1983), and was substantiated by potentiometric data (Kuniansky, 1990) and the relief on the base of the Edwards Group (G.E. Groschen, U.S. Geological Survey, written commun., 1988).

The boundary between the Edwards Plateau and the Balcones fault zone is somewhat arbitrary through eastcentral Kinney County (fig. 2). This segment of the boundary is intended to separate the area where the Edwards-Trinity aquifer is the principal aquifer from the area where the Edwards aquifer is the principal aquifer. This delineation was based on geophysical and transmissivity data.

The topography of the Balcones fault zone smooths gulfward from the Balcones escarpment, which approximately coincides with the 1,000-ft topographic contour (fig. 3). The Edwards aquifer crops out over much of the Balcones fault zone (figs. 2, 3). However, the downward displacement of the faulted strata and the steepening slope of the sediments above the Ouachita structural belt (figs. 5, 6) cause the Edwards aquifer to be hydraulically confined and progressively more deeply buried beneath the Navarro-Del Rio confining unit southeast of the outcrop area.

The broad stream valleys in downgradient parts of the Hill Country narrow where the streams enter the Balcones fault zone and flow onto the relatively permeable Edwards Group (Wermund and Woodruff, 1977, p. 342). The streams leak appreciable amounts of water to the Edwards aquifer as they flow over the intensively faulted outcrop area of the Edwards Group. Hydraulic heads in confined parts of the Edwards aquifer mostly are above land surface near the freshwater/saline-water transition zone, resulting in several large springs that discharge from downgradient parts of the freshwaterflow system. Comal and San Marcos Springs (fig. 3) discharge at rates that average more than $100 \mathrm{ft}^{3} / \mathrm{s}$.

Precipitation over the Edwards-Trinity aquifer system averaged about $20 \mathrm{in} / \mathrm{yr}$ during 1951-80 (Riggio and others, 1987, fig. 11). During this time, precipitation averaged about 28 in/yr over the Balcones fault zone, about $30 \mathrm{in} / \mathrm{yr}$ over the Hill Country, about $19 \mathrm{in} / \mathrm{yr}$ over the Edwards Plateau, and about 13 in/yr over the Trans-Pecos. The distribution of perennial streams (fig. 3 ) attests that considerably more precipitation falls on the eastern part of the aquifer system than on the western part. The rising topography and increasing distance from the Gulf of Mexico (the principal source of moisture) cause the average annual precipitation to decrease from east to west (Carr, 1967, p. 2). Moistureladen air from the Gulf cools and releases precipitation as the air masses progress inland. The rising, relatively rugged terrain north of the Balcones escarpment makes the orographic effect on precipitation especially evident over the Hill Country.

May and September generally are the months of greatest precipitation in the Balcones fault zone, Hill 


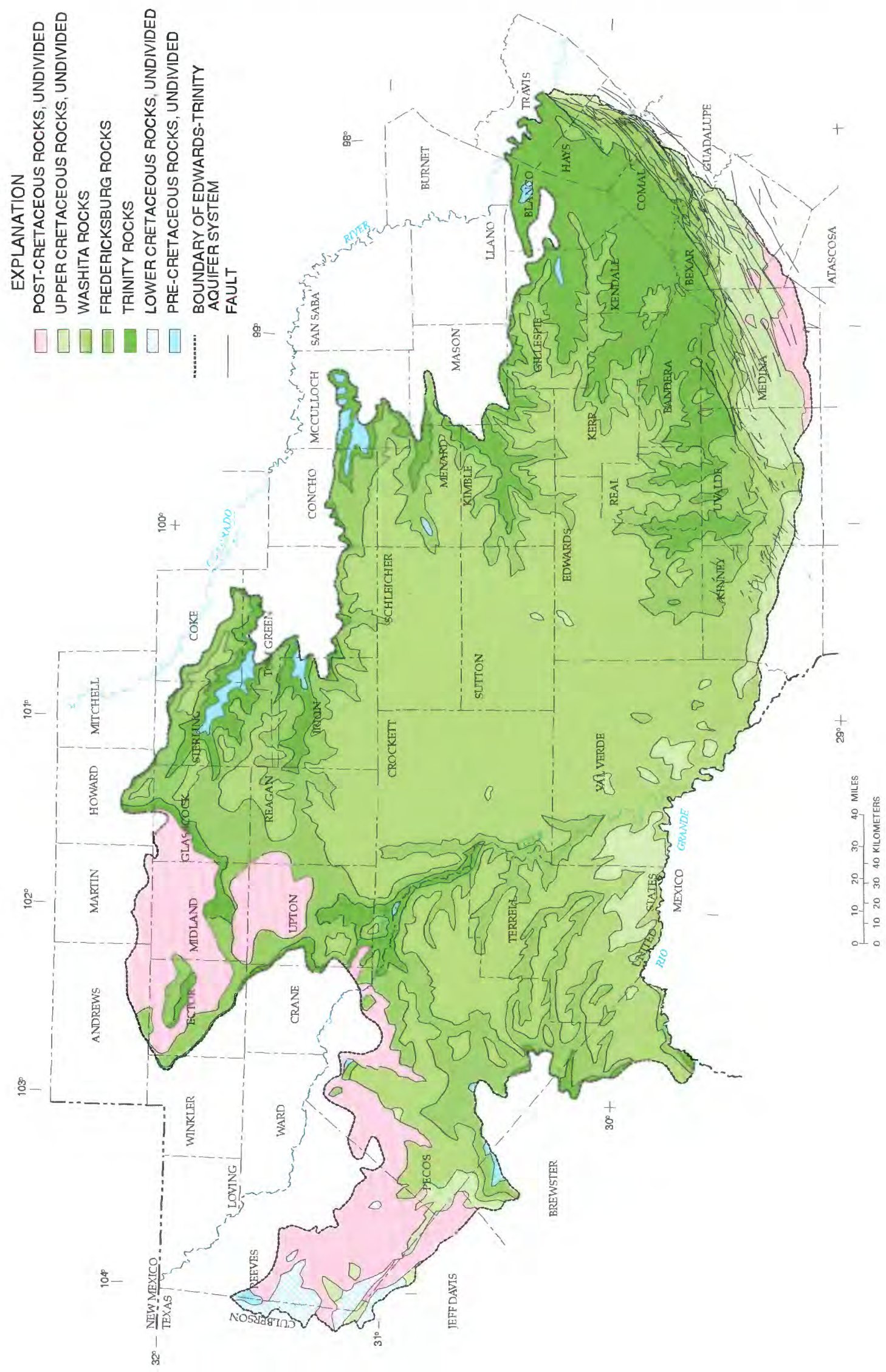




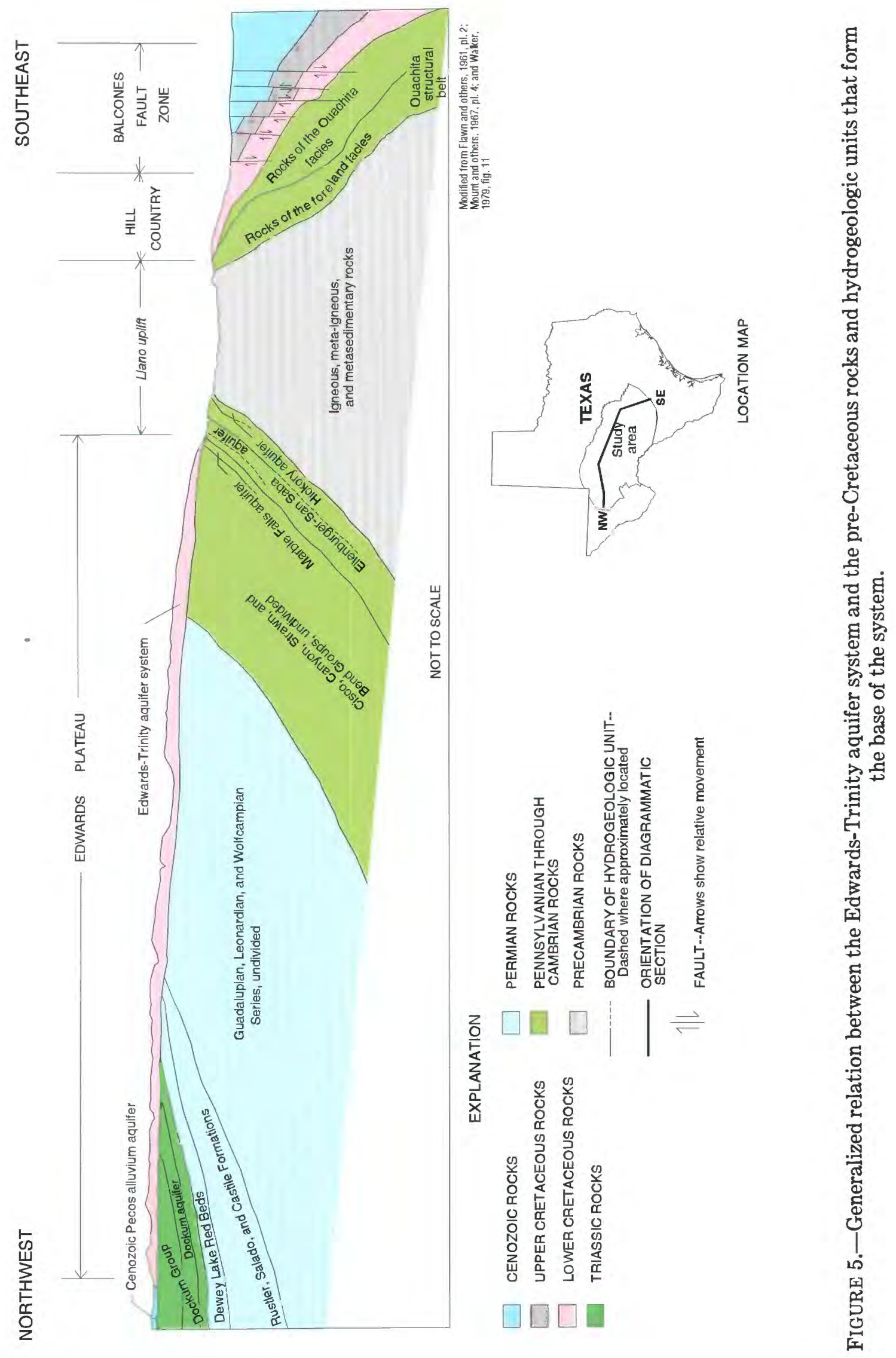




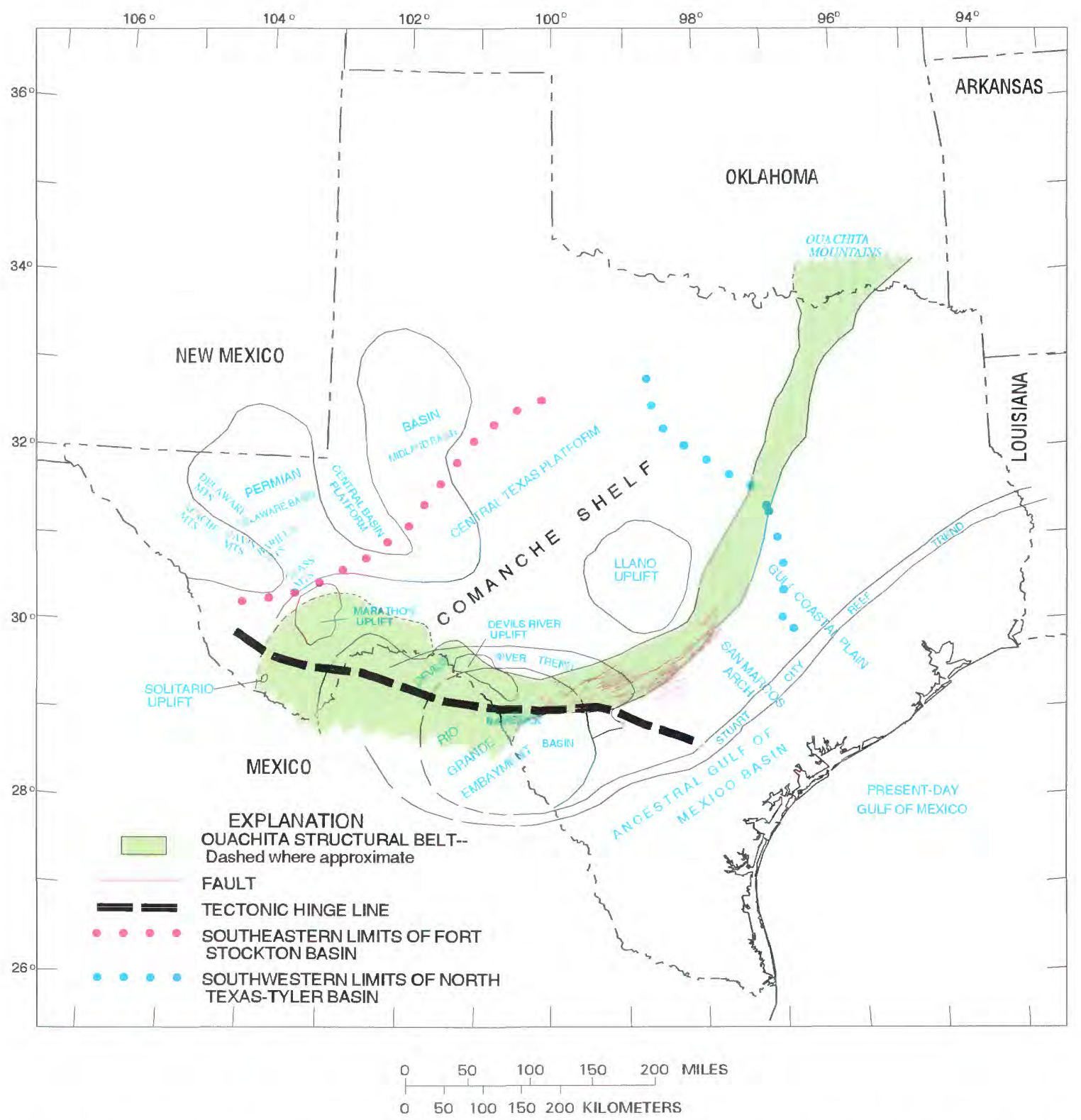

FIGURE 6.-Paleogeographic and structural features in west-central Texas and parts of adjacent States and northern Mexico.

Country, and Edwards Plateau. Precipitation in the Trans-Pecos is infrequent and typically limited to small areas, and primarily results from convective showers and thunderstorms in July, August, and September (Carr, 1967, p. 14; Linsley and others, 1975, p. 61).

\section{PREVIOUS WORK AND ACKNOWLEDGMENTS}

Previous reports on the hydrogeology of west-central Texas generally cover less area than the regional scale of the RASA project. Therefore, interpretations and descriptions in this report were synthesized from the published results of several agencies, companies, and institutions - in addition to the unpublished records of a few individuals. Chief contributors of the published data used in this report are the U.S. Geological Survey, the Bureau of Economic Geology of the University of Texas at Austin, and the former Texas Department of Water Resources (TDWR)-now separated into the Texas Water Development Board (TWDB) and the Texas Natural Resource Conservation Commission (TNRCC). 
TABLE 1.-Carbonate-rock classification systems adapted from Dunham (1962) and Folk (1962)

\begin{tabular}{|c|c|c|c|c|c|}
\hline \multicolumn{6}{|c|}{ Carbonate-rock classification system from Dunham (1962) } \\
\hline \multicolumn{5}{|c|}{ DEPOSITIONAL TEXTURE RECOGNIZABLE } & \multirow[b]{6}{*}{$\begin{array}{l}\text { (Subdivide according } \\
\text { to classifications } \\
\text { designed to bear on } \\
\text { physical texture or } \\
\text { diagensis.) }\end{array}$} \\
\hline \multicolumn{4}{|c|}{ Original components not bound together during deposition } & \multirow{5}{*}{$\begin{array}{l}\text { Original components were } \\
\text { bound together } \\
\text { during deposition...as } \\
\text { shown by intergrown } \\
\text { skeletal matter, lamination } \\
\text { contrary to gravity, or } \\
\text { sediment-floored cavities } \\
\text { that are roofed over by } \\
\text { organic or questionably } \\
\text { organic matter and are too } \\
\text { large to be interstices. }\end{array}$} & \\
\hline \multicolumn{3}{|c|}{$\begin{array}{l}\text { Contains mud } \\
\text { (particles of clay and fine silt size) }\end{array}$} & \multirow[t]{4}{*}{$\begin{array}{l}\text { Lacks mud and is } \\
\text { grain-supported }\end{array}$} & & \\
\hline \multicolumn{2}{|c|}{ Mud-supported } & \multirow[t]{3}{*}{ Grain-supported } & & & \\
\hline $\begin{array}{l}\text { Less than } \\
10 \text { percent } \\
\text { grains }\end{array}$ & $\begin{array}{l}\text { More than } \\
10 \text { percent } \\
\text { grains }\end{array}$ & & & & \\
\hline Mudstone & Wackestone & & & & \\
\hline
\end{tabular}

\begin{tabular}{|c|c|c|c|c|c|c|c|c|}
\hline \multicolumn{9}{|c|}{ Carbonate-rock classification system from Folk (1962) } \\
\hline & \multicolumn{4}{|c|}{ MORE THAN 2/3 LIME MUD MATRIX } & \multirow{2}{*}{$\begin{array}{l}\text { SUB- } \\
\text { EQUAL } \\
\text { SPAR } \\
\text { AND } \\
\text { LIME } \\
\text { MUD }\end{array}$} & \multicolumn{3}{|c|}{ MORE THAN 2/3 SPAR CEMENT } \\
\hline $\begin{array}{l}\text { Percent } \\
\text { allochems }\end{array}$ & $\begin{array}{c}0-1 \\
\text { percent }\end{array}$ & $\begin{array}{c}1-10 \\
\text { percent }\end{array}$ & $\begin{array}{c}10-50 \\
\text { percent }\end{array}$ & $\begin{array}{l}\text { More than } \\
50 \text { percent }\end{array}$ & & $\begin{array}{l}\text { Sorting } \\
\text { poor }\end{array}$ & $\begin{array}{l}\text { Sorting } \\
\text { good }\end{array}$ & $\begin{array}{c}\text { Rounded } \\
\text { and abraded }\end{array}$ \\
\hline $\begin{array}{l}\text { Representa- } \\
\text { tive } \\
\text { rock terms }\end{array}$ & $\begin{array}{l}\text { Micrite and } \\
\text { dismicrite }\end{array}$ & $\begin{array}{l}\text { Fossilif- } \\
\text { erous } \\
\text { micrite }\end{array}$ & $\begin{array}{c}\text { Sparse } \\
\text { biomicrite }\end{array}$ & $\begin{array}{l}\text { Packed } \\
\text { biomicrite }\end{array}$ & $\begin{array}{c}\text { Poorly } \\
\text { washed } \\
\text { biosparite }\end{array}$ & $\begin{array}{l}\text { Unsorted } \\
\text { biosparite }\end{array}$ & $\begin{array}{l}\text { Sorted } \\
\text { biosparite }\end{array}$ & $\begin{array}{l}\text { Rounded } \\
\text { biosparite }\end{array}$ \\
\hline $\begin{array}{c}1959 \\
\text { terminology }\end{array}$ & $\begin{array}{l}\text { Micrite and } \\
\text { dismicrite }\end{array}$ & $\begin{array}{l}\text { Fossilif- } \\
\text { erous } \\
\text { micrite }\end{array}$ & \multicolumn{3}{|c|}{ Biomicrite } & \multicolumn{3}{|c|}{ Biosparite } \\
\hline
\end{tabular}

Publications of the American Association of Petroleum Geologists and the Geological Society of America and some unpublished dissertations and theses from the University of Texas (at Austin and at Arlington) also were useful. The carbonate-rock terminology used in this report (table 1) is based on classification procedures recommended by Dunham (1962) and Folk (1962).

Much of the geologic information on the western and southern parts of the study area was summarized for this report from unpublished data provided by Dr. C.I. "Ike" Smith, former Chairman of the Department of Geology at the University of Texas at Arlington. The authors are greatly indebted to Dr. Smith for his enthusiastically shared knowledge about the Cretaceous rocks of southwestern Texas and northern Mexico.

\section{GEOLOGIC SETTING}

\section{DEPOSITIONAL, TEGTONIC, AND DIAGENETIC CONDITIONS}

The depositional, tectonic, and diagenetic conditions that characterize the rocks that form the EdwardsTrinity aquifer system are strikingly different from those of the underlying, comparatively impermeable pre-Cretaceous rocks. The typically medium- to thinbedded Cretaceous strata of the aquifer system mostly dip southeastward atop generally massive, westwarddipping Paleozoic and Triassic units (fig. 5). The unconformity between the Cretaceous rocks of the aquifer system and the pre-Cretaceous complex (Barker and Ardis, 1992) marks a major shift in the geologic evolution of 
the study area. This hiatus in the rock record spans about 60 million years of crustal warping and erosion between the deposition of terrestrial red beds during Late Triassic time and the deposition of terrigenous clastic and shallow-marine carbonate sediments during Early Cretaceous time. The following discussion summarizes the geologic history of the pre-Cretaceous rocks upon which the Cretaceous seas encroached and reconstructs the depositional, tectonic, and diagenetic activity from the beginning of the Cretaceous Period to the present. The discussion is limited to processes affecting the hydrology of the Edwards-Trinity aquifer system.

\section{PRE-GRETAGEOUS HISTORY}

The pre-Cretaceous geologic history of west-central Texas was dominated by (1) an elongated depositional trough called the Ouachita geosyncline, (2) land masses located south and east of the geosyncline that were the primary sources of clastic sediment, and (3) shallow inland seas over a stable continental foreland located north and west of the geosyncline. From southeastern Oklahoma, the Ouachita geosyncline extended around the southeastern and southern margins of the Llano and Devils River uplifts to the southeastern and eastern margins of the Marathon and Solitario uplifts (fig. 6). The Llano and Devils River uplifts were resistant promontories of Precambrian crystalline rock on the southern margin of ancestral North America. The geosyncline might have resulted from subduction associated with the ancestral (pre-Gulf of Mexico) positioning of the North American and Afro-South American continental plates (Walper and Miller, 1985). Presently, the Ouachita geosyncline is represented by the mostly buried Ouachita structural belt (Flawn and others, 1961).

While the coarsest Paleozoic deposits accumulated in the Ouachita geosyncline, comparatively fine-grained deposits of mostly organic and chemical origin formed in the foreland area (Sellards, 1935, p. 18). During the 400 million years preceding Late Cambrian sedimentation, uplift and erosion prevailed over deposition (Flawn, 1956). During the Late Cambrian through Mississippian time, about $5,000 \mathrm{ft}$ of mostly carbonate strata formed in the foreland area atop an unevenly eroded surface of folded and faulted Precambrian rocks. Intermittent pulses of uplift and volcanic activity maintained prominent land areas along the cratonic margins of the geosyncline, which provided the subsiding trough with coarse, largely quartzose clastic sediments. Deposition rates quickened during the Pennsylvanian Period, and this faster rate of sedimentation continued through Early Permian time. More than $5,000 \mathrm{ft}$ of marine sandstone, limestone, and shale accumulated in the foreland area during Pennsylvanian through Early
Permian time. The geosynclinal deposits continued to subside rapidly through most of this time and reached depths of more than $20,000 \mathrm{ft}$ before succumbing to orogeny.

The Ouachita orogeny climaxed between Late Pennsylvanian and Early Permian time, when the geosynclinal deposits were uplifted, thrust faulted, and intensively folded into a Late Paleozoic mountain range. The mountains extended from Mississippi, through the Ouachita Mountains of Arkansas and Oklahoma, to the Marathon and Solitario uplifts of Texas. Sediments in the Ouachita geosyncline underwent incipient to low-grade metamorphism, with strong shearing and hydrothermal effects, as the Paleozoic rocks were thrust northward (Flawn and others, 1961). The Llano and Devils River uplifts were resistant buttresses against which the Ouachita facies were thrust. Intervening rocks of the foreland facies were sheared and folded (Webster, 1980), which created petroleum traps and some of the most productive oil and gas reservoirs in the world. Interior parts of the Ouachita facies were altered to marble, phyllite, schist, slate, or related products of heat and pressure.

During the waning stages of the Ouachita orogeny, the Permian Basin (fig. 6) developed in west Texas beneath a broad, shallow sea. The sea became increasingly saline as the basin became more isolated from the open ocean about the middle of Late Permian time, a time of intense aridity (King, 1942, p. 711-763). Detrital influx to the Permian Basin eventually ceased and the predominate sediments became gypsum, anhydrite, halite, and potash. Following uplift and erosion toward the end of Late Permian time, the connection between the Permian Basin and open ocean improved and the highly saline water was gradually replaced by fresher seawater. Fine-grained clastic sediments (probably eroded from slightly higher areas to the south, west, and north) were deposited as a relatively thin red-bed unit above the older evaporitic strata. The sea withdrew from the Permian Basin as West Texas was uplifted at the close of the Paleozoic Era.

The withdrawal of the Permian sea was followed by long periods of nondeposition, crustal warping, and erosion during Early through Middle Triassic time. As uplift continued in the Llano area and erosion planed down the central basin platform (fig. 6), a closed continental basin formed over much of west-central Texas and eastern New Mexico. During Late Triassic time, Paleozoic rocks were eroded from the surrounding high ground and redeposited in low-lying fluvial, deltaic, and lacustrine environments as red beds of the Dockum Group (McGowen and others, 1979, p. 6).

West-central Texas was above sea level during most of the Jurassic Period. During this time, the landscape 
was tilted toward the southeast and eroded to a rolling peneplain. The Wichita Paleoplain, as it was named by Hill (1901), was characterized by broad river valleys and low ridges of resistant rocks. The ancestral Ouachita Mountains were deeply eroded across central Texas and the remnants subsided rapidly as the Gulf of Mexico began to open (Flawn, 1964, p. 271-274). The continental interior tilted southeastward across the subsiding Ouachita structure, causing a reversal in the direction of surface drainage. The reversal in drainage, which might have begun late in the Permian Period, was completed by the end of the Jurassic Period. Accordingly, the earlier pattern of northwestward drainage toward a closed continental basin was superseded by southeastward drainage toward a westwardadvancing Cretaceous sea (Sellards, 1933, p. 24).

\section{GRETACEOUS PERIOD}

Rifting and subsidence in the ancestral Gulf of Mexico basin (fig. 6) continued into the Cretaceous Period (Wood and Walper, 1974). A broad continental shelf nearly encircled the basin, bridging the Yucatan Peninsula of Mexico and southern parts of Texas, Louisiana, Mississippi, Alabama, and Florida with the Bahama Islands (Bebout and Loucks, 1974, p. 2). The Cretaceous strata of the Edwards-Trinity aquifer system (pl. 1) formed atop, and landward of, this continental shelf. While alluvial plains inland of a westward-advancing Comanchean sea were dominated by clastic deposition, shallow offshore environments-characterized by warm, generally clear seawater-promoted the biogenic accumulation of calcium carbonate. Comparatively deep, open-shelf environments subsequently supported the widespread deposition of mostly calcareous Gulf strata.

Although during Trinitian time the Llano uplift was an imposing structural feature on an otherwise rolling peneplain composed of folded and faulted preCretaceous rocks, its importance decreased throughout the remainder of the Cretaceous Period. By Fredericksburgian time, the uplift had been eroded to such a low altitude that it contributed little sediment. However, the Llano uplift (together with the San Marcos arch) remained high enough to keep depositional environments in the Maverick basin isolated from those in the north Texas-Tyler basin (fig. 6) through most of Washi$\tan$ time. The Llano uplift subsequently was buried by more than $1,000 \mathrm{ft}$ of Upper Cretaceous (mostly Gulfian) strata.

\section{Comanchean Epoch: Trinitian Age}

Subsidence in the ancestral Gulf of Mexico basin (fig. 6), coupled with eustatic rises in sea level, caused the Early Cretaceous sea to advance westward over an eroded, uneven surface of pre-Cretaceous rocks (fig. 7). Islands of Precambrian metamorphic and igneous rocks and Paleozoic sedimentary rocks stood high on the Llano uplift and shed clastic debris into the encroaching Trinitian sea (Stricklin and others, 1971, p. 7). The Trinity rock record indicates a cyclic pattern of shoreline advance and retreat, superimposed upon an overall pattern of marine transgression. The transgressions were interrupted occasionally by short-lived regressions, which left comparatively little sediment. The regressions probably were triggered by a lowering of sea level, decreasing rates of subsidence, increases in the supply of clastic sediment from rising inland source areas, or some combination of these conditions (McFarlan, 1977, p. 10). The lateral and vertical distributions of the Trinity rock units (pl. 1) are shown in figures 8 and 9 , respectively.

The gradational nature of the Trinity rock record is indicated on the southern flank of the Llano uplift (fig. 8), where basal terrigenous deposits overlap preCretaceous rocks (fig. 9, $H-H^{\prime}$ ) and grade upward into carbonate sediments. From less than $150 \mathrm{ft}$ thick near the Llano uplift, the Trinity rock sequence thickens downdip to more than $1,000 \mathrm{ft}$ thick in the Balcones fault zone. The wedge-like Trinity rock units are diachronous (time-transgressive) toward the Llano uplift, which largely controlled the structural setting and depositional environments during Trinitian time.

The Trinity rocks in the study area were deposited during three major transgressive-regressive cycles of sedimentation. Stricklin and others (1971) regarded the rock record of each cycle as a "clastic-carbonate couplet" characterized by terrigenous clastic deposits on the bottom and marine carbonate sediments on top. Each couplet documents a major advance of the Early Cretaceous sea, terminated by an overall drop in sea level or a dynamic equilibrium between the land and sea. The couplets are separated by disconformities and generally onlap rocks of the previous cycle. From oldest to youngest, the couplets are composed of (1) the Sycamore Sand (Hosston Formation, downdip) and Sligo Formation; (2) the Hammett Shale (Pine Island Shale Member of the Pearsall Formation, downdip) and Cow Creek Limestone (Cow Creek Limestone Member, downdip); and (3) the Hensel Sand (Bexar Shale Member, downdip) and Glen Rose Limestone.

While aggrading streams deposited detrital sand and gravel of the Sycamore Sand on the southern flank of the Llano uplift (Inden, 1974), calcareous mud and silt of the Hosston Formation (Bebout and others, 1981) accumulated offshore in a transgressing sea. Dolomitic siltstone and rhythmically bedded mudstone of the Sligo Formation (Stricklin and others, 1971) were 


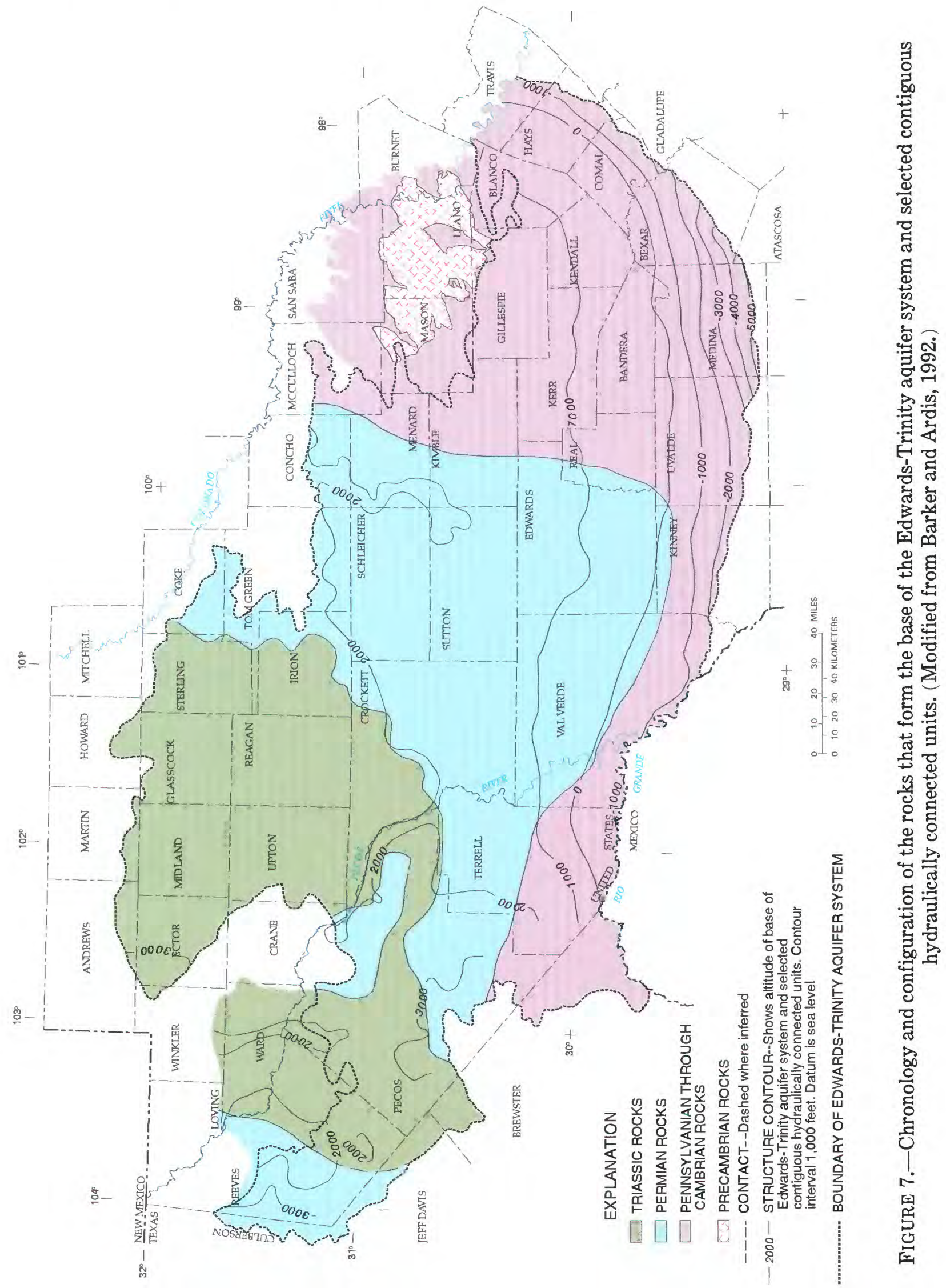




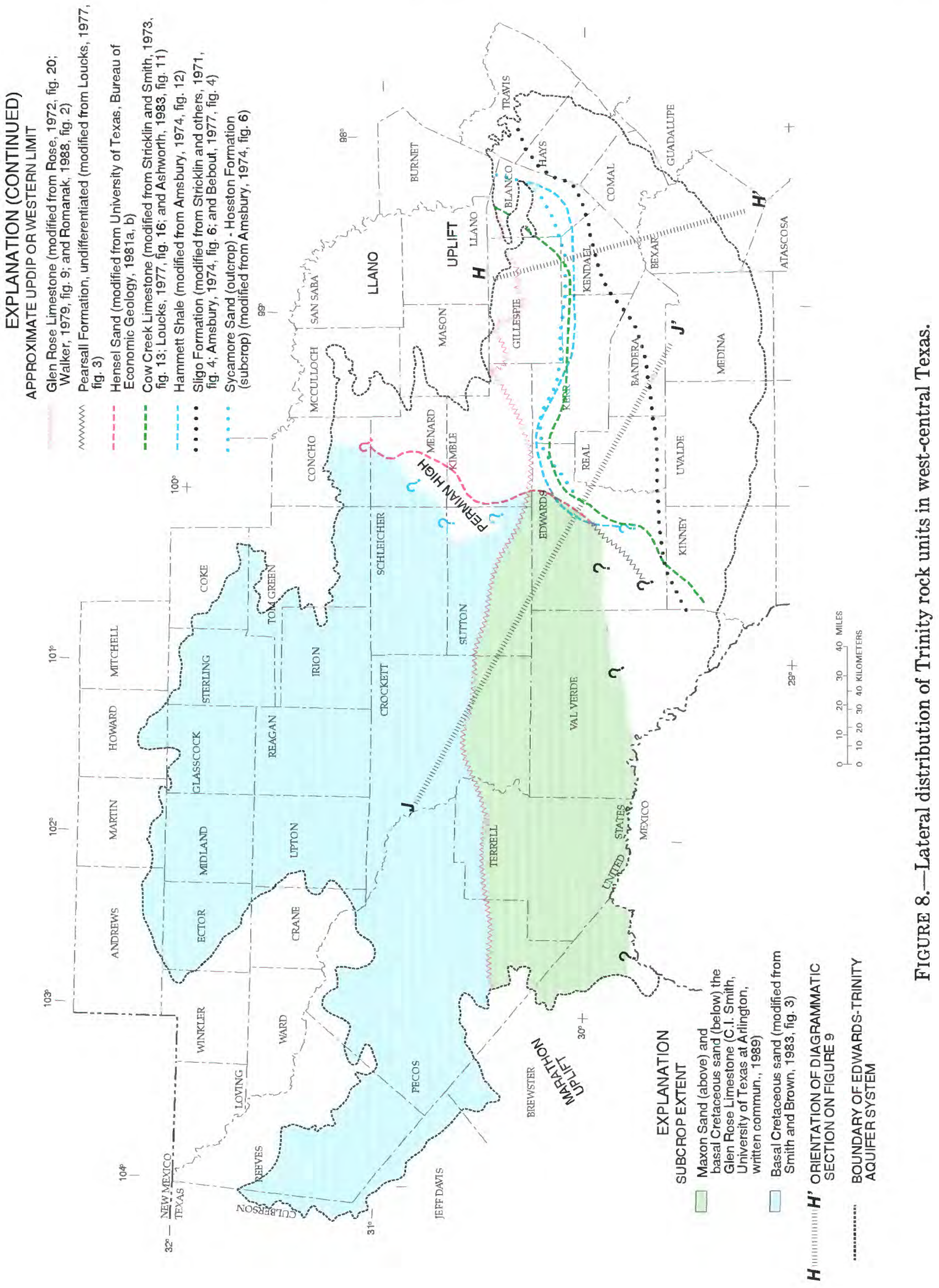




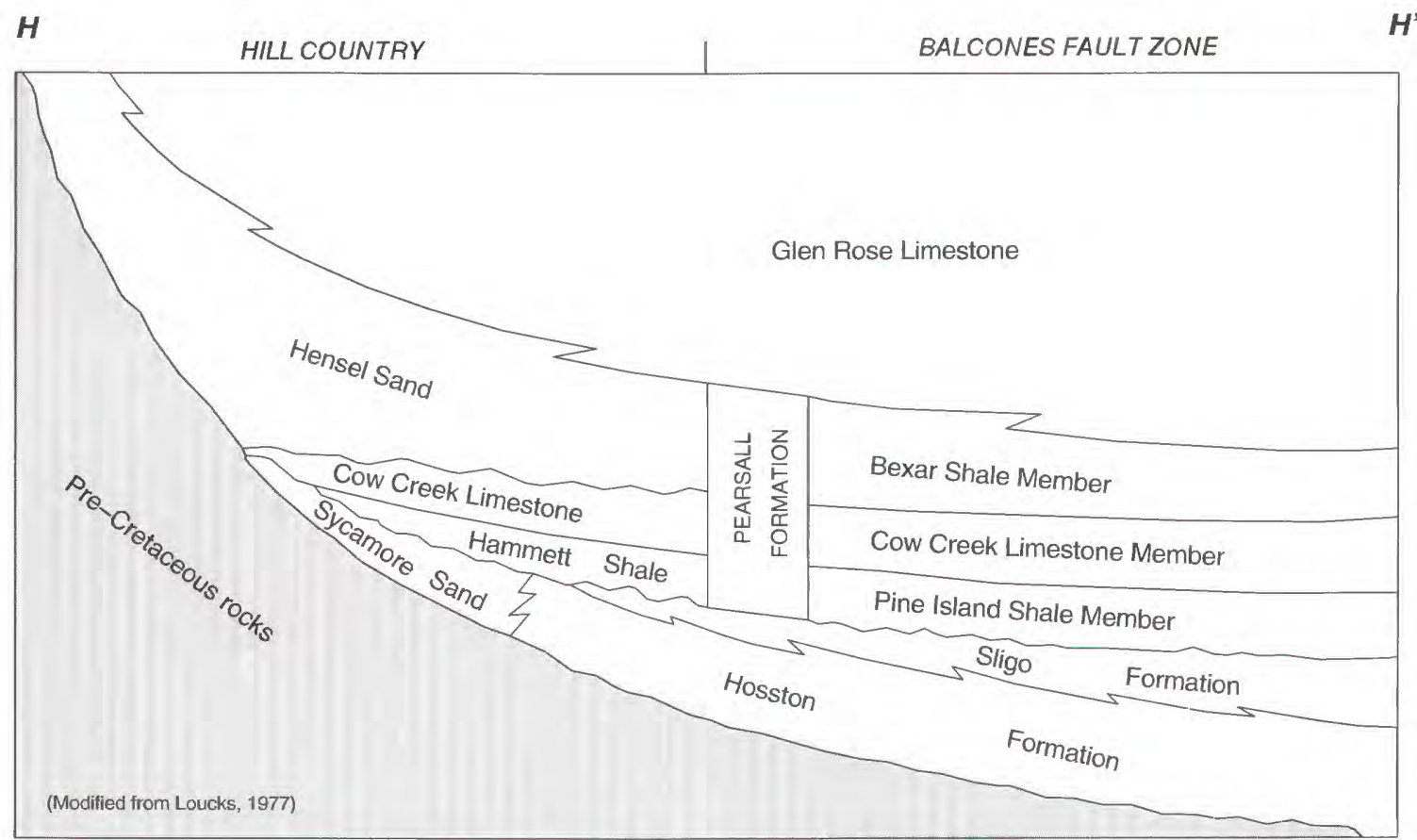

NOT TO SCALE

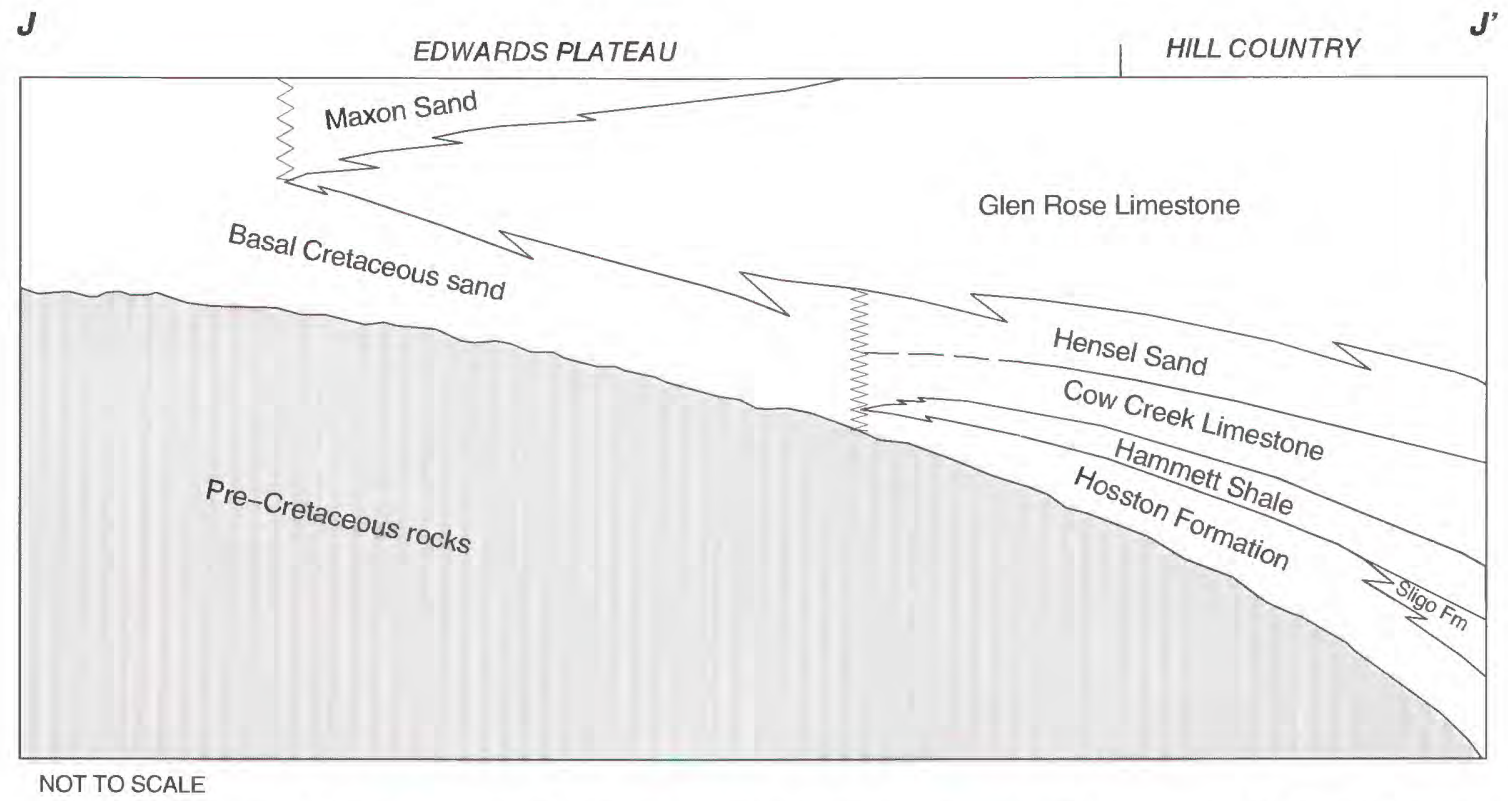

FIGURE 9.-Vertical distribution of Trinity rock units in west-central Texas and their relation to geographic subareas. (See fig. 8 for orientation of diagrams.)

deposited above the Hosston Formation in a mostly regressive lower Trinity sea whose shoreline approached but never reached the updip limit of Sycamore Sand (fig. 8).

Following a period of sea level lowering and subaerial exposure, the middle Trinity sea rapidly trans- gressed inland over deeply weathered and eroded surfaces of Sligo Limestone and Sycamore Sand and deposited the argillaceous Hammett Shale (Stricklin and others, 1971, p. 14). The Hammett Shale and its downdip equivalent, the Pine Island Shale Member of the Pearsall Formation, mostly were deposited in an 
unusually quiet body of seawater, such as a broad lagoon or open embayment, where water salinities ranged from normal marine to brackish (Amsbury, 1974 , p. 22). Carbonate sedimentation dominated during deposition of the Hammett Shale, as the production of carbonate mud increased and the influx of clastic detritus decreased.

The Cow Creek Limestone formed as mostly highenergy, beach-dominated environments prograded seaward from the Llano uplift (Stricklin and Smith, 1973). Depositional conditions were controlled principally by a shelf profile that steepened prior to Cow Creek deposition and a regressive sea that persisted through the end of middle Trinitian time. Lower parts of the Cow Creek Limestone appear to have been deposited offshore under gradually shoaling conditions. Coquina in the upper parts are thought to have formed within a shoreline reentrant, where mollusk shells furnished by slackened longshore currents were sorted by waves refracted against the curved shoreline of the reentrant (Stricklin and Smith, 1973). High-gradient streams transported Precambrian igneous and metamorphic detritus and Paleozoic sedimentary rock fragments from the Llano uplift to the shoreline, where they mixed with the shell debris and extended the land area. As the reentrant filled and the shoreline stabilized, upper parts of the beach became subaerially exposed. An irregular topography and pockets of caliche developed atop parts of the Cow Creek Limestone, as unconsolidated sediments were redistributed by the wind and storm waves, and infiltrating meteoric water leached carbonate surfaces.

Further subsidence initiated the third and final major transgression of the Trinity sea. The Bexar Shale Member of the Pearsall Formation (Forgotson, 1957, p. 2,347) was deposited as a mixture of terrigenous clastic and marine carbonate sediments in the "fine-grained distal part" of a deltaic system that prograded seaward from the Llano uplift (Loucks, 1977, p. 106). The Hensel Sand formed in the updip part of this system, where alluvial fans on the flanks of the Llano uplift coalesced into a low-lying coastal plain. The coastal plain merged on the south and east with the shallow-marine environment of the Bexar Shale. The basal Cretaceous sand (Romanak, 1988) formed west of the Llano uplift (fig. 8), where typically it amassed as a sprawling, braided stream deposit atop an eroded surface of preCretaceous rocks (fig. 9, $J-J^{\prime}$ ).

As sandy red beds of the updip Hensel Sand formed in terrestrial settings around the Llano uplift, the Glen Rose Limestone accumulated to the southwest (above the basal Cretaceous sand) and south (above the Bexar Shale) in low-energy, shallow-marine environments. During early Glen Rose time, rudist reefs and bio- stromes flourished in pockets of well-circulated water of less-than-normal salinity (Perkins, 1974; Petta, 1977). The reef structures vanished as hypersaline conditions dominated late Glen Rose time in response to reduced water circulation and increased aridity (Stricklin and Amsbury, 1974). The upper member of the Glen Rose Limestone mostly formed in restricted environments dominated by broad tidal flats in the lee of an incipient Stuart City reef trend (fig. 6) that began to build along the shelf edge during middle to late Trinitian time.

The rate of regional subsidence during middle to late Trinitian time was greatest toward the south. As a result, the Glen Rose Limestone is more than three times as thick in southern Kinney County as in central Sutton County (pl. 6). Jager (1942, p. 384) attributed this southward thickening to the rapid sinking of the Rio Grande embayment (fig. 6). Trinity rocks in the study area were deposited over the northern flank of the Rio Grande embayment (Murray, 1961, p. 128).

The sea withdrew from the study area during late Trinitian time. As the shoreline receded toward the south and east, the carbonate-producing marine environments of the Glen Rose Limestone were replaced in the southwestern part of the study area by a fluvialdeltaic system that deposited the Maxon Sand (King, 1980, p. 21). While sandy and silty red beds of the Maxon Sand accumulated atop the Glen Rose Limestone between southern Pecos County and central Edwards County (fig. 8), the upper part of the Glen Rose Limestone mostly was exposed as a broad tidal mudflat east of Edwards County. The evaporites and thin beds of dolomitic and marly limestone that formed upon the mudflat were dominated by consolidation, cementation, and weathering (Lozo and Smith, 1964, p. 291). (Mud cracks, algal structures, ripple marks, dinosaur tracks, and clam borings characteristic of the depositional settings are preserved near the top of the Glen Rose Limestone.) The shoreline receded at the end of Trinitian time to a position parallel to and slightly north of the present-day Balcones fault zone.

\section{Comanchean Epoch: Fredericksburgian and Washitan Ages}

By early Fredericksburgian time, an offshore bioherm of rudists, corals, and calcareous sediment had grown to an almost continuous reef-island ridge along the seaward edge of the continental shelf in the ancestral Gulf of Mexico basin (Bebout and Loucks, 1974, p.6). This shelf margin ridge, called the Stuart City reef trend (Winter, 1962), extended from northern Mexico across nearly $500 \mathrm{mi}$ of southeastern Texas (fig. 6). The aggressive upward growth of the Stuart City reef trend during Fredericksburgian through most of Washitan 
time probably resulted from an abrupt rise in sea level that might have been triggered by an increase in the rate of sea-floor spreading (Bay, 1977, p. 17).

The Stuart City reef trend sheltered depositional environments in the study area from storm waves and deep ocean currents in the ancestral Gulf of Mexico. While water depths exceeded $1,000 \mathrm{ft}$ in the basin, they ranged from a few feet to generally less than $100 \mathrm{ft}$ on the carbonate platform upon which the rocks of the Edwards-Trinity aquifer system formed. While dark, argillaceous sediments characterized by planktonic foraminifera accumulated basinward in reducing environments, calcareous strata containing warm-water organisms formed in shallow-marine environments on the carbonate platform (Bebout and Loucks, 1974, p. 2-6). Evaporitic and dolomitic strata formed upon tidal flats, which occupied the higher elevations of the carbonate platform and frequently were subjected to subaerial exposure, oxidation, and erosion.

The Fredericksburg and lower Washita strata of westcentral Texas were deposited landward of the Stuart City reef trend, largely on a part of the continental shelf known as the Comanche shelf (Rose, 1972). According to C.I. Smith (University of Texas at Arlington, written commun., 1989), depositional environments on the Comanche shelf were controlled by the (1) distribution and rates of subsidence and uplift, (2) influx of finegrained terrigenous sediment, and (3) extent of water circulation, or degree of restriction relative to that of the open sea. The resulting lithofacies determine the stratigraphy and, together with the effects of postdepositional tectonics and carbonate diagenesis, the hydraulic characteristics of rocks that compose the Edwards-Trinity aquifer system.

Structural features of the Comanche shelf that most strongly affected Fredericksburg and Washita deposition are shown in figures 6 and 10. The lateral and vertical distributions of the resulting rock units are shown in figures 11 and 12, respectively.

The central Texas platform was an elongated mound on the Comanche shelf (figs. 6, 10) that extended from northwest of the Llano uplift to approximately the San Angelo area (fig. 11). The San Marcos arch, a somewhat narrower structural high, extended southeast from the Llano uplift to the Stuart City reef trend. By early Fredericksburgian time, the most prominent parts of the Llano uplift probably had been eroded to a few lowstanding islands in the Cretaceous sea. However, because the Llano uplift bridged the central Texas platform and San Marcos arch, depositional environments in the study area generally were isolated from those of north Texas. The Maverick basin, which today straddles the boundary between Texas and Mexico, was a semicircular depression along the southern margin of the
Comanche shelf. The Devils River trend, a narrow carbonate bank composed largely of rudists and reef debris, developed around the northern and western margins of the Maverick basin during middle Fredericksburgian through early Washitan time. The Devils River trend, together with the Stuart City reef trend, virtually surrounded the Maverick basin, which contributed to the uniqueness of the lithofacies that formed inside the basin. The Fort Stockton basin was a slowly subsiding marine embayment extending from northern Mexico across the northwestern part of the Comanche shelf.

During Fredericksburgian through early Washitan time, the central Texas platform (figs. 6, 10) was dominated by supratidal, intertidal, and restricted shallowmarine depositional environments (fig. 13). During periods of especially low sea level and extreme aridity, the crest of the central Texas platform became a broad, sabkha-type mudflat where evaporites, dolostone, and thin-bedded dolomitic limestone were deposited (Fisher and Rodda, 1966). Comparatively thick-bedded, rudist-bearing, bioclastic carbonate strata were deposited concurrently on the southwestern flank of the central Texas platform in mostly open shallow-marine to open-shelf environments. Here, the water typically was deeper and the circulation generally was less restricted than in the tidal flat environments that prevailed over the crest of the central Texas platform. Marly carbonate strata were deposited at this time in the Fort Stockton basin, an open-marine embayment of moderately deep, quiet water.

The eastern part of the Fort Terrett Formation and the Segovia Formation (Rose, 1972) formed near the crest of the central Texas platform mostly in supratidal to restricted shallow-marine environments. The western part of the Fort Terrett Formation and the Fort Lancaster Formation (Scott and Kidson, 1977) formed mostly in open shallow-marine to open-shelf environments transitional to those on the central Texas platform and in the Fort Stockton basin.

The Finlay Formation, a cliff-forming limestone with quartz sand in the lower part and rudists in the upper part (Reaser and Malott, 1985), formed in the Fort Stockton basin during Fredericksburgian time-when the basin primarily was a shallow, open lagoon. The Boracho Formation (Brand and Deford, 1958) was deposited later in a deeper, shelf-basin environment that received fine-grained terrigenous sediment from west of the study area (fig. 13). The fine-grained, siliciclastic nature of the Boracho Formation inhibited the precipitation of calcium carbonate and growth of rudists in the Fort Stockton basin during Washitan time (C.I. Smith, University of Texas at Arlington, oral commun., 1989). 


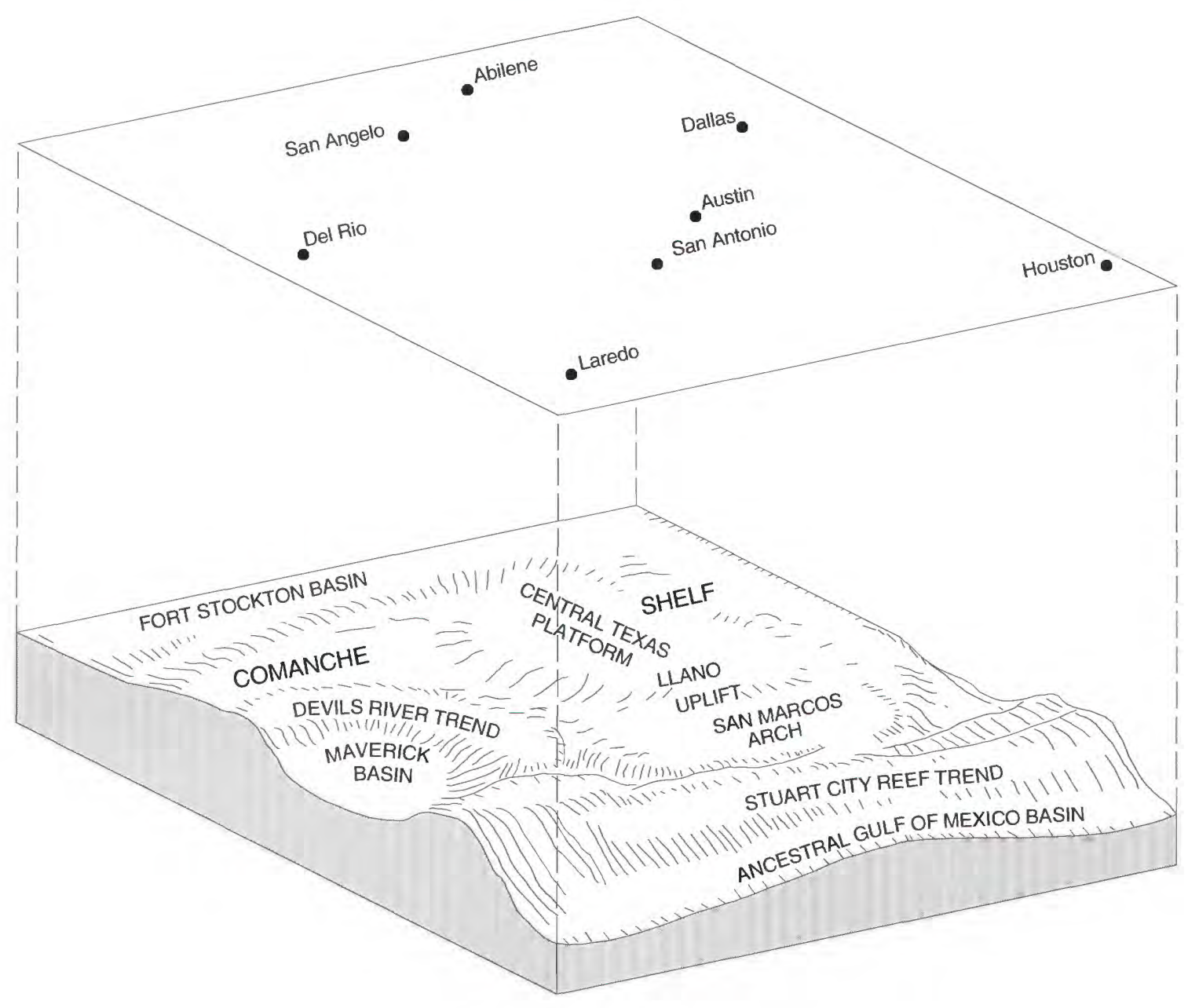

NOT TO SCALE

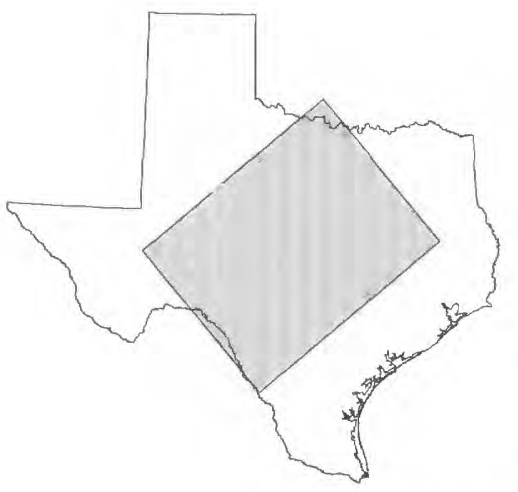

LOCATION MAP

FIGURE 10.- Structural controls on the deposition of Fredericksburg and Washita strata of the Edwards-Trinity aquifer system. (Modified from Rose, 1972, fig. 2.) 


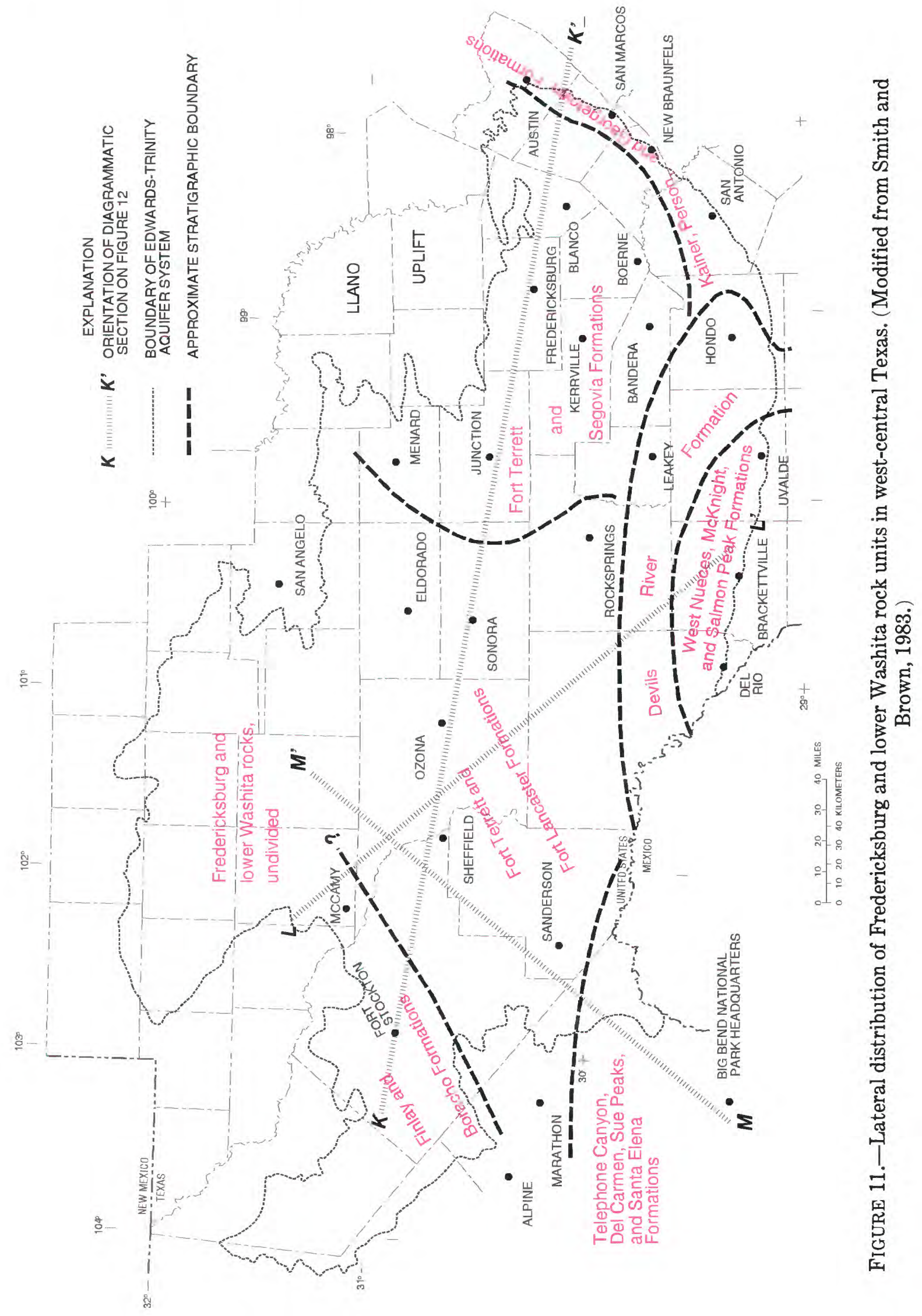


K

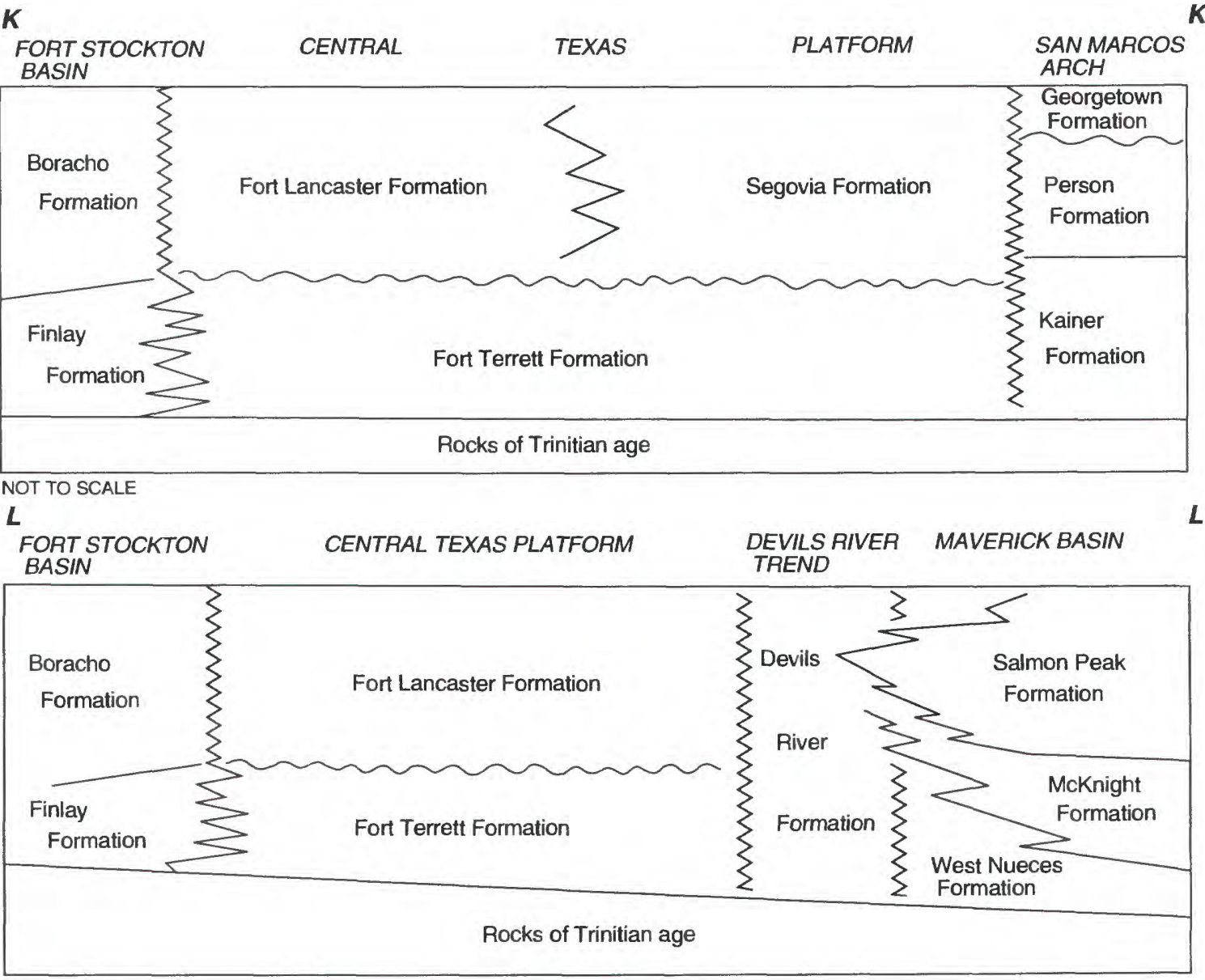

NOT TO SCALE

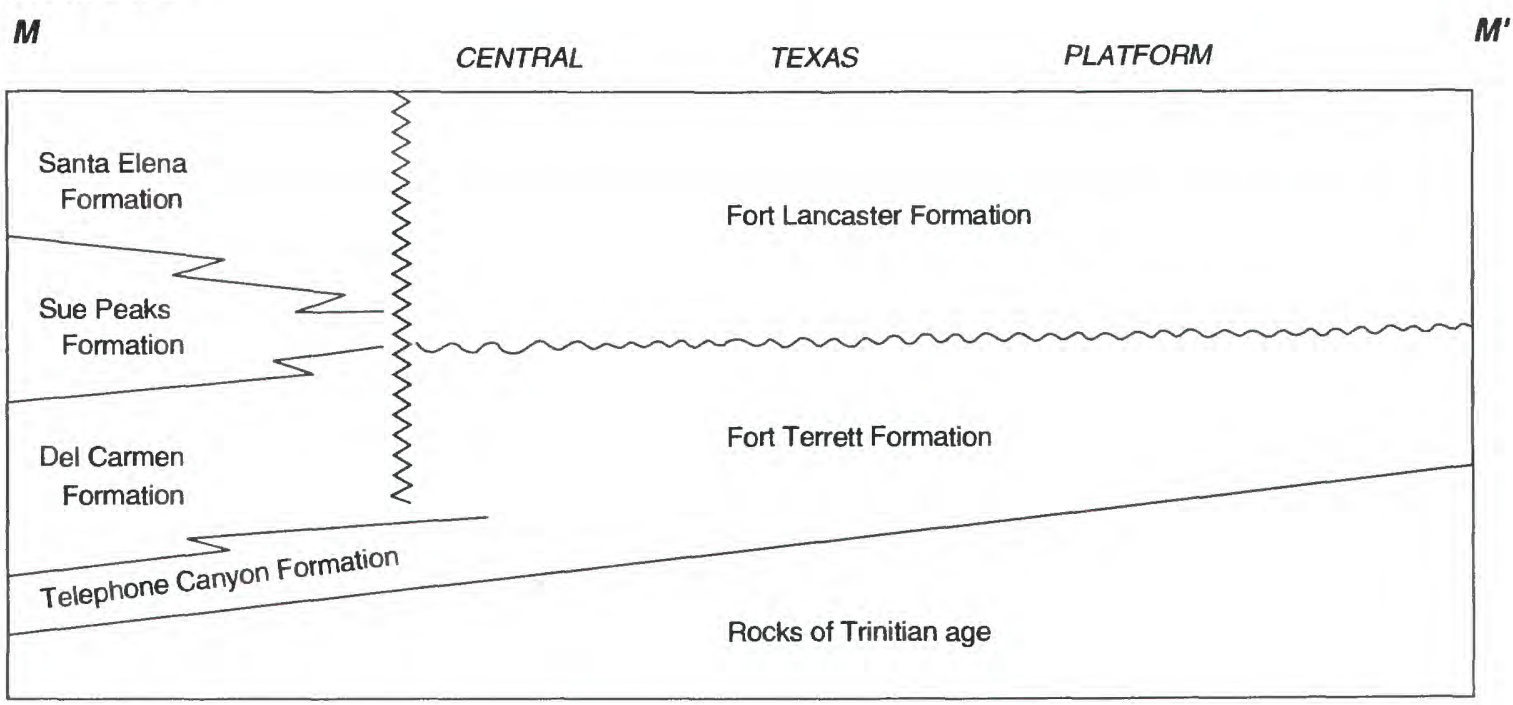

NOT TO SCALE

FIGURE 12.-Vertical distribution of Fredericksburg and lower Washita rock units in westcentral Texas (modified from Smith and Brown, 1983), and their relation to depositional environments. (See fig. 11 for orientation of diagrams.) 

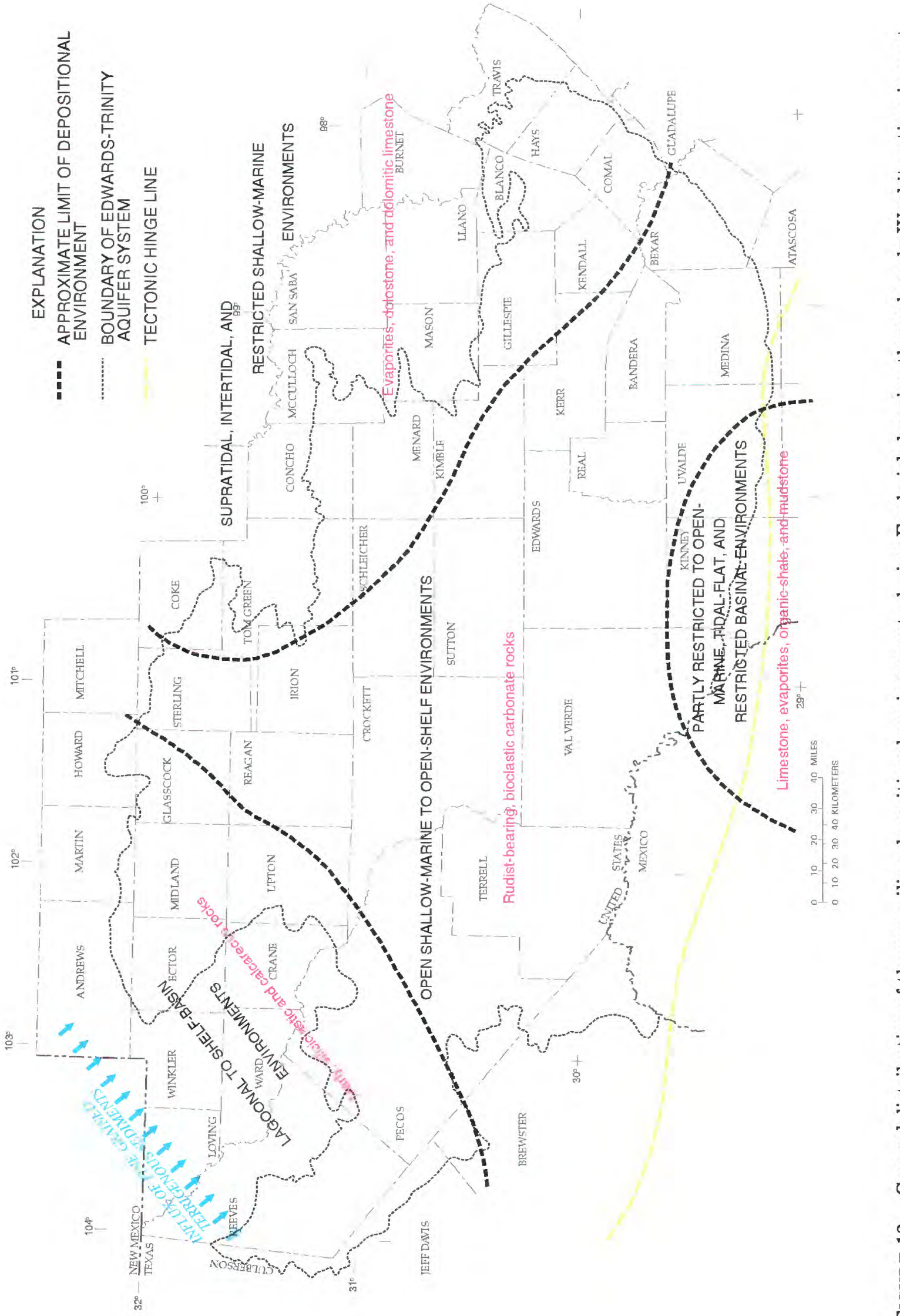
The San Marcos arch was dominated by shallowwater deposits upon tidal flats that frequently underwent uplift, subaerial exposure, and erosion. The parts of the Kainer and Person Formations (Rose, 1972) that formed over this arch are characterized by lateral facies changes, structural thinning, and erosional surfaces.

Although depositional environments on the central Texas platform and on the San Marcos arch generally became shallower during Fredericksburgian through early Washitan time, major subsidence south of a tectonic hinge line (figs. 6, 13) kept parts of southwestern Texas and northern Mexico more deeply submerged. The tectonic hinge line (Smith, 1981, p. 4) extended from the San Marcos arch westward across the southern parts of Medina, Uvalde, and Kinney Counties to the Big Bend area of Texas (fig. 3). Greater rates of subsidence south of the hinge line caused fundamental differences between the lithology of rocks deposited on the southwestern flank of the central Texas platform and those deposited in the Maverick basin (C.I. Smith, University of Texas at Arlington, oral commun., 1989).

In contrast to many depositional breaks north of the tectonic hinge line, the persistently submerged Maverick basin received sediment almost continuously during Fredericksburgian through most of Washitan time. Depositional environments inside the basin generally were buffered from those more typical of the central Texas platform by an intervening zone of comparatively unrestricted circulation, moderate-tohigh wave and current energy, and aggressive reef growth (the Devils River trend, figs. 6, 10). The resulting bank of carbonate sediment and reef debris is mapped as the Devils River Formation (fig. 11, pl. 1). The Devils River trend on the west and north, together with the Stuart City reef trend on the east and south, nearly encircled the Maverick basin and helped isolate the lithofacies of the Maverick basin from those elsewhere in the study area.

Bioclastic limestone of the West Nueces Formation (Lozo and Smith, 1964) formed mostly below wave base during early stages of the Maverick basin when the area typically was dominated by partly restricted to openmarine environments and approximately normal seawater. Later, as water salinities increased, the intertidal to shallow subtidal environments that produced the West Nueces Formation and lower parts of the McKnight Formation gave way to evaporite precipitation on a broad mudflat that sloped inland from the Stuart City reef trend (Miller, 1984). Water depths that initially had increased between the Stuart City reef trend and the Devils River trend suddenly reversed in response to accelerated rates of subsidence (C.I. Smith, University of Texas at Arlington, oral commun., 1989) south of the tectonic hinge line (figs. 6, 13). The associ- ated basinward increase in water depth caused gypsiferous tidal flat deposits near the top of the lower McKnight sequence to prograde northward, over the West Nueces Formation, into the Devils River trend (fig. 12, $L-L^{\prime}$ ).

Water circulation deteriorated markedly inside the Maverick basin as the stature of the Stuart City and Devils River (reef) trends evolved and the basin continued to deepen. A thin-bedded, finely laminated sequence of mudstone, which composes middle parts of the McKnight Formation, formed in an euxinic, basinal environment (Carr, 1987, p. 70) that produced dark organic shale and petroliferous limestone, with minor amounts of sulfur. As water depths subsequently decreased to perhaps 150 or $200 \mathrm{ft}$, thin beds of anhydrite and argillaceous mudstone accumulated in slightly fresher water to form upper parts of the McKnight Formation. The McKnight Formation eventually was covered with more than $300 \mathrm{ft}$ of dense, medium- to thick-bedded mudstone that composes the lower two-thirds of the Salmon Peak Formation (Humphreys, 1984). The lower few hundred feet of the Salmon Peak Formation formed in open to partly restricted basinal environments, where water depths probably ranged from about 300 to about $600 \mathrm{ft}$. Toward the end of Salmon Peak deposition (late Washitan time), the Stuart City reef trend began to disintegrate and the connection improved between the Maverick basin and open sea (C.I. Smith, University of Texas at Arlington, oral commun., 1989). The uppermost 75 to $100 \mathrm{ft}$ of the Salmon Peak Formation formed as partly reworked grainstone and wackestone deposits prograded southward from the Devils River trend.

Concurrent with deposition inside the Maverick basin, the surrounding Devils River trend produced a stratigraphically undifferentiable bank of partly to completely dolomitized miliolid, shell-fragment, and rudist-bearing limestone (Lozo and Smith, 1964, p. 291-297). Nodular, burrowed, dolomitic, and evaporitic rock sequences that compose lower parts of the Devils River Formation were laid down during Fredericksburgian time in partly restricted tidal flat environments somewhat similar to those on the southwestern flank of the central Texas platform (Miller, 1984). Deeper water and comparatively unrestricted circulation allowed rudist reefs to flourish during most of Washitan time around the northern perimeter of the Maverick basin, where upper parts of the Devils River Formation formed in mostly open shallow-marine environments of moderate-to-high wave and current energy. The reefs might have emerged from the sea intermittently during middle Washitan time when they are believed to have been extensively leached, 
dolomitized, and recrystallized (R.W. Maclay, U.S. Geological Survey, written commun., 1987).

The geologic histories of the Maverick basin and the Devils River trend are complex because of wide ranging depositional, tectonic, and diagenetic conditions. For detailed accounts of these conditions and their effects, the reader is referred to Humphreys (1984, p. 34-59) and Miller (1984, p. 3-33).

Toward the end of early Washitan time and continuing into late Washitan time, the sea withdrew from the central Texas platform in response to tectonic upwarping of the Comanche shelf (Rose, 1972, p. 71). Soil and caliche horizons developed on emergent northwestern parts of the central Texas platform (Smith and Brown, 1983, p. 23). Freshwater marl and limestone formed in marshy environments on the lower-lying southeastern margin of the platform (Halley and Rose, 1977, p. 213215). Approximately $100 \mathrm{ft}$ of lower Washita strata was eroded from the crest of the San Marcos arch and upper surfaces of the remaining rocks were karstified (Hammond, 1984). Much of the paleokarst and many of the caverns that today occur in the Edwards Plateau (Kastning, 1983) probably originated during the Washitan episodes of subaerial exposure.

The open sea returned during Washitan time and the Georgetown Formation-a nodular, slightly argillaceous, generally thin-bedded limestone-was deposited over the San Marcos arch. Bioclastic sand and carbonate mud belonging to upper parts of the Segovia and Fort Lancaster Formations were deposited during this time over the central Texas platform in relatively shallow, well-circulated seawater (Rose, 1972, p. 71). A shoalingupward pattern of deposition prevailed around the northern margin of the Maverick basin, where the deposits reflect the effects of sediment reworking and moderate-to-high wave and current velocities. The upper part of the Salmon Peak Formation formed when a tongue of mostly grainstone prograded southward over the Maverick basin from the Devils River trend (fig. 12, $L-L^{\prime}$ ). By this time, the rate of reef growth in the Devils River trend probably exceeded the rate of subsidence in the Maverick basin (Humphreys, 1984, p. 56).

Following regional uplift near the end of Washitan time and the additional erosion of sediments from the crest of the central Texas platform, the open sea returned once again to west-central Texas. The Comanche shelf was blanketed by the Del Rio Clay. Silt, clay, and marly limestone of this relatively thin, open-marine deposit topped the Maverick basin, which by late Washitan time was no longer a distinct depositional basin. Carbonate sedimentation decreased sharply as fine-grained, terrigenous sediment began to dominate and impede the growth of carbonateproducing organisms in environments no longer shel- tered by the Maverick basin or Stuart City reef trend (C.I. Smith, University of Texas at Arlington, oral commun., 1989).

Following uplift of the central Texas Platform just before the end of Washitan time, erosion stripped much-and in places, all-upper Washita strata from the study area. The sea returned near the end of Washitan time and blanketed west-central Texas with an open-shelf mudstone known today as the Buda Limestone.

\section{Gulfian Epoch: Eaglefordian through Navarroan Ages}

During Eaglefordian (early Gulfian) through Navarroan (late Gulfian) time, the Buda Limestone was covered with 2,000 to perhaps $4,000 \mathrm{ft}$ of sandstone, shale, marl, and chalk (Waters and others, 1955, p. 1,831). Except for some Eagle Ford sediments in the southwestern part of the study area that possibly were deposited by high-energy oceanic currents (C.I. Smith, University of Texas at Arlington, oral commun., 1989), most of the Gulf strata formed in low-energy, open-shelf environments. Accordingly, most of the Gulf strata are fine-grained, strongly cemented, and virtually impermeable to ground water (Maclay and Small, 1986, table 1).

Near the end of the Cretaceous Period, the study area entered a prolonged interval of uplift in association with the Laramide orogeny and Basin and Range deformation of northern Mexico (Henry and Price, 1985; Ewing, 1991). Subsequent erosion has removed most Gulf strata from the study area. The remaining Gulf rocks include sparse outcrops and shallow subcrops of Eagle Ford and Austin strata in the Edwards Plateau and in the Trans-Pecos and relatively thick, steeply dipping Eagle Ford-through-Navarro strata above the Ouachita structural belt (fig. 6). The Cretaceous rocks of the study area are separated from the Cenozoic rocks by a major unconformity (Adkins, 1933).

\section{POST-CRETACEOUS HISTORY}

The post-Cretaceous geologic history of west-central Texas was dominated by widespread uplift and erosion, concurrent with deposition in the Gulf of Mexico. During the Cenozoic Era, a thick succession of offlapping deltaic deposits built the Gulf Coastal Plain with detritus eroded from Paleozoic and Mesozoic rocks on the uplifted continental interior (Wilhelm and Ewing, 1972). Cenozoic deposits in the study area include thick deposits of Tertiary and Quaternary alluvium along the Pecos River and sparse remnants of the (1) upper Tertiary Ogallala Formation, (2) Pliocene (Uvalde gravel) and Pleistocene terrace deposits, and (3) Holocene streambed deposits. Only the thick 
deposits of Cenozoic alluvium along the Pecos River markedly affect the hydrology of the Edwards-Trinity aquifer system.

A large volume of Cretaceous rock was removed from the northwestern part of the study area during late Mesozoic through early Cenozoic time as the result of structural deformation, salt dissolution, and erosion along what is now the Pecos River valley. As Paleozoic sediments in the Delaware basin (fig. 6) were uplifted in association with the Laramide orogeny (Henry and Price, 1985), deformation of massive Upper Permian salt deposits caused faulting and fracturing within the overlying Triassic and Cretaceous strata (Wessel, 1988, fig. 14). Solution channels formed in the deep subsurface as fresh ground water penetrated the structurally deformed terrain and dissolved halite, gypsum, and anhydrite from the Upper Permian rocks (Maley and Huffington, 1953). Eventually, the overlying strata collapsed into the hollow subsurface, forming two elongate troughs (pl. 2) between the southeastern corner of New Mexico and the northwestern part of Pecos County (Ashworth, 1990). The troughs filled during Tertiary and Quaternary time with more than $1,500 \mathrm{ft}$ of talus and alluvial fill, known as the Cenozoic Pecos alluvium.

During early Tertiary time, as uplift dominated the western part of the study area, sediments east of the Ouachita structural belt (fig. 6) continued to subside into the Gulf of Mexico (Walper and Miller, 1985). Tensile stresses accumulated in the Cretaceous rocks where they arched over the Ouachita structural belt (Flawn, 1956, p. 32). The crustal tension culminated between late Oligocene through early Miocene time (Weeks, 1945 ) with a series of discontinuous, generally en echelon and mostly down-to-the-southeast faults. These faults profoundly changed the landscape of central Texas (fig. 14).

The Balcones fault zone is defined by a series of highangle normal faults that are aligned with the Ouachita structural belt where it bends around the southeastern margin of the Llano uplift (fig. 6). The faults disrupt Lower Cretaceous through Paleocene strata at the surface (Murray, 1961, p. 176) and extend downward into Paleozoic rocks of the Ouachita facies (fig. 5). The alignment of the faults probably is influenced by lines of weakness, including relic faults, in the Ouachita structural belt (Flawn and others, 1961, p. 190). Maximum vertical displacements are observed over the San Marcos arch in Bexar, Comal, Hays, and Travis Counties. Weeks $(1945$, p. 1,734$)$ estimated that the total vertical displacement across the Balcones fault zone was about $1,200 \mathrm{ft}$ near San Antonio and about $900 \mathrm{ft}$ near Austin.

The Balcones faulting disrupted the lateral continuity of Cretaceous strata (fig. 14) and initiated hydrogeo- logic conditions that ultimately produced the Edwards aquifer of the Balcones fault zone (Maclay and Small, 1986), one of the most permeable and productive aquifers in the Nation. The Cretaceous strata were displaced vertically, fractured intensively, and rotated differentially within a series of southwest-to-northeast trending fault blocks that characterize the fault zone. Groundwater flow shifted toward the northeast in response to rejuvenated hydraulic gradients in that direction and high-angle barrier faults that blocked old, southeastward flowpaths. New flowpaths developed subparallel to the strike of the fault zone as evaporites and soluble calcareous constituents (other carbonate minerals and allochems) dissolved from the fractured strata and discharged to downgradient springs and streams.

Springs originated in topographically low areas where barrier faults intercepted the lateral flow of confined water at depth and diverted it to the surface along paths of least resistance (Abbott, 1977). Aquifers developed as flowpaths converged toward spring outlets, and the rocks became more permeable through dissolution. Solution channels spread outward from the springs, and zones of honeycombed and cavernous porosity evolved into major conduits of ground-water flow (Woodruff and Abbott, 1986, p. 77). The major springs (fig. 3) persisted and control modern potentiometric levels and discharge patterns (Bush and others, 1993).

Streams that before the faulting had meandered gulfward under low gradients were out of equilibrium with the faulted topography. Although most of the old (prefault) watercourses had flowed generally eastward, headward erosion by the new (post-fault) streams cut northwestward across the Balcones escarpment (fig. 3) toward the Edwards Plateau. Many of the older, eastflowing streams were pirated by the younger, highergradient streams that formed normal to the escarpment (Woodruff and Abbott, 1986, fig. 5). The rates of downcutting increased after piracy, as larger volumes of discharge resulted from the newly acquired headwaters.

Stream erosion eventually breached the overlying, low-permeability Gulf rocks and provided discharge areas for aquifers in the underlying, more permeable Comanche rocks. All but minor remnants of Fredericksburg and Washita strata were removed from a 20- to 50mi-wide area between the Balcones fault zone and the Edwards Plateau. This area, the Hill Country, is characterized today by vast outcrops of irregularly eroded Trinity strata.

The rocks in the Hill Country, Edwards Plateau, and Trans-Pecos mostly were excluded from the largescale normal faulting, intensive fracturing, and subsequent dissolution that controlled the origin of the Edwards aquifer in the Balcones fault zone. 

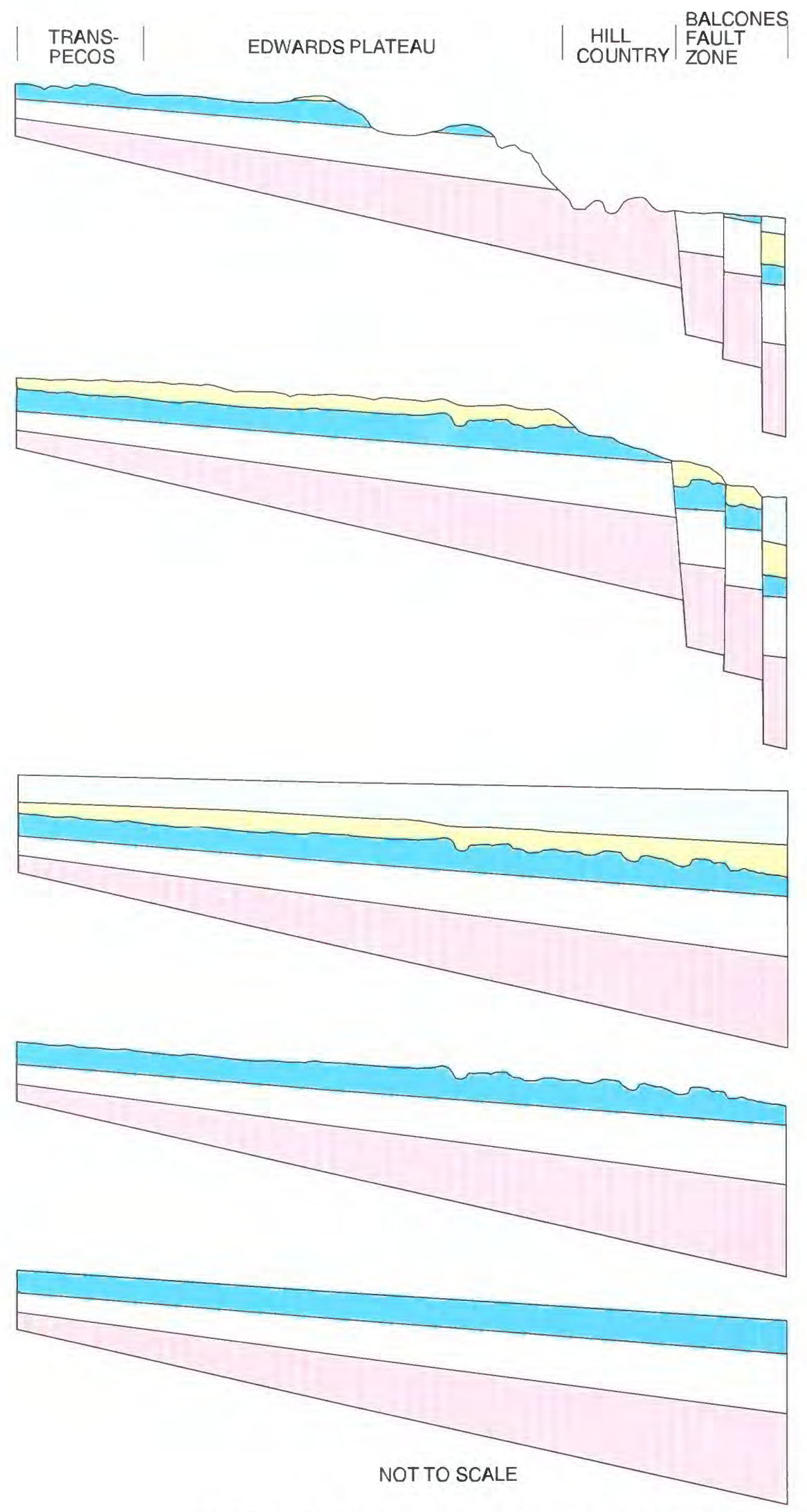

FIGURE 14.-Progression of major depositional, tectonic, and diagenetic 


\section{QUATERNARY}

Base level of surface drainage lowers as streams erode deeper into uplifted strata west of Balcones fault zone; Hill Country stripped of most post-Trinity strata: hydraulic conductivity of strata outside fault zone decreases through cementation, recrystallization, and replacement; hydraulic conductivity of Edwards Group inside fault zone increases through dissolution and dedolomitization; joint cavities, solution channels, and honeycombed zones continue to enlarge-increasing the transmissivity of Edwards aquifer; dynamic equilibrium between freshwater and saline water reached across freshwater/saline-water transition zone.

TERTIARY: Oligocene - Miocene Epochs

Cretaceous strata displaced vertically as much as 1,200 feet in Balcones fault zone by high-angle normal faults. culminating tensional buildup in strata above Ouachita structural belt, as Gulf of Mexico subsides; fractures in fault zone widen as erosional unloading progresses; ground-water flow diverted toward northeast by barrier faults: hydraulic conductivity increases through dissolution of previously buried evaporites, magnesium calcite, and aragonitic constituents as meteoric water enters faulted terrain and circulates through fractures and downdropped paleokarst; dolomite replaced by calcite through dedolomitization; micrite recrystallizes to coarse microspar and pseudospar; headward erosion toward upthrown Edwards Plateau initiates dissection of terrain west of fault zone; Gulf strata eroded and redeposited gulfward.

\section{LATE CRETACEOUS}

Karst, marl, soil, and caliche surfaces buried by upper Washita strata (following regional subsidence) and Gulf strata (following collapse of Stuart City reef trend); calcite cementation abates: karst development ceases; carbonate sediments undergo compaction, with stylolitization in deeply buried facies.

\section{LATE-EARLY CRETACEOUS: Following middle Washitan uplift}

Lower Washita strata exposed subaerially following uplift of Comanche shelf; approximately 100 feet of strata eroded from crest of San Marcos arch; San Marcos arch and central Texas platform locally karstified; primary porosity enlarged through dissolution of evaporitic and calcareous constituents in shallow zones of freshwater circulation, with carbonate cementation downgradient; freshwater marl, soil, and caliche horizons formed over central Texas platform.

\section{EARLY CRETACEOUS}

Trinity, Fredericksburg and lower Washita strata deposited mainly in terrestrial, supratidal, intertidal, and shallow marine environments on slowly subsiding carbonate platform in lee of Stuart City reef trend; aragonitic constituents, high-magnesium calcite. and evaporites leached early by locally circulated meteoric water; breccia zones formed by collapse of overlying beds; supratidal carbonate deposits dolomitized and gypsum precipitated; aragonite and magnesium calcite cements formed in marine environments.
EXPLANATION GULF ROCKS

Eaglefordian through Navarroan age COMANCHE ROCKS

Late Washitan age

Early Washitan age

Fredericksburgian age

Trinitian age

events affecting development of the Edwards-Trinity aquifer system. 
Consequently, the hydraulic characteristics of the Trinity and Edwards-Trinity aquifers more closely resemble those of each other than those of the Edwards aquifer.

Outside the Balcones fault zone, the dominant effects of carbonate diagenesis (Bathurst, 1975) on the hydraulic characteristics of the Edwards-Trinity aquifer system have resulted most importantly from cementation, recrystallization, and neomorphism. (Neomorphism is a comprehensive term to describe processes of recrystallization and replacement where the mineralogy might have changed or where the mechanism of change is impossible to distinguish (Folk, 1962, p. 20-21).) While cementation destroyed primary intergranular porosity, recrystallization sharply reduced the intercrystalline porosity of most carbonate rocks. The mineralogically unstable minerals, high-magnesium calcite and aragonite, mostly were replaced by low-magnesium calcite, the most stable form of calcium carbonate. Because cementation, recrystallization, and replacement typically reduced or obliterated the primary porosity of most carbonate rocks outside the fault zone, the hydraulic conductivity of aquifers in the Hill Country, Edwards Plateau, and Trans-Pecos typically has decreased over geologic time.

Within the Balcones fault zone, however, the hydraulic conductivity of carbonate strata typically has increased over time as the result of large-scale normal faulting, coupled with the associated fracturing and subsequent dissolution. The faulting vertically displaced the terrain, which increased hydraulic gradients and helped initiate a dynamic regime of shallow ground-water flow. In addition to forming new porosity (within the fractures), the fracturing increased the hydraulic conductivity by interconnecting voids that, before the faulting, had been isolated. The dissolution of evaporites and soluble calcareous constituents formed moldic and other forms of fabric-selective porosity (Choquette and Pray, 1970) that increased hydraulic conductivity locally. Dissolution along fractures and bedding planes formed joint cavities and solution channels that eventually became the principal conduits of regional ground-water flow (Woodruff and Abbott, 1986, p. 77). The increases in hydraulic conductivity were greatest in shallow parts of the fault zone because fractures typically close with increasing depth below land surface and dissolution is most active near the interval of water-table fluctuation (LeGrand and Stringfield, 1971, p. 1,286).

A dynamic regime of shallow freshwater circulation probably has existed in the Balcones fault zone since Miocene time (Ellis, 1986), after the brunt of the faulting ruptured the thick overburden of hydraulically tight Gulf strata and exposed the relatively permeable upper Comanche strata to meteoric conditions (fig. 14). The concentration of high-angle faults and associated fractures facilitated the percolation of meteoric water and extended the depth of freshwater diagenesis. The partial pressure of dissolved carbon dioxide, derived from the atmosphere and soil to form carbonic acid, increased the solubility of calcareous constituents. Previously leached strata (paleokarst) provided incipient avenues through which meteoric water could enter and dissolved constituents could exit the shallow subsurface. The hydraulic conductivity of the Edwards aquifer increased rapidly in humid post-fault environments, as evaporites (principally anhydrite and gypsum), other unstable minerals (such as aragonite and high-magnesium calcite), and allochems (fossil parts, intraclasts, pellets, and oolites) dissolved along fractures, bedding planes, and burrows (Abbott, 1975, p. 255-267).

Additional increases in the hydraulic conductivity of the Edwards aquifer resulted from dedolomitization (Maclay and Small, 1986, p. 31), a form of incongruent dissolution in which dolomite in the presence of dissolved gypsum is replaced by calcite. Dedolomitization is a near-surface phenomenon (De Groot, 1967) prompted by the addition of calcium ions through the dissolution of gypsum and the removal of magnesium ions through freshwater flushing (Back and others, 1983). Although dedolomitization, by itself, might not necessarily increase hydraulic conductivity, the resulting "calcite after dolomite," or dedolomite, can be more soluble than the original dolomite (Evamy, 1967). The enhanced hydraulic conductivity of dolomitic strata in the Balcones fault zone probably results most importantly through the dissolution of the secondary calcite that resulted from dedolomitization.

Dedolomite in the Edwards aquifer does not appear to have resulted from pre-Miocene diagenesis, nor does it appear related either to ancient or to recent weathering surfaces (Ellis, 1986, p. 109). Dedolomitization in the Balcones fault zone would have required the rapid influx of meteoric water and the rapid flushing of magnesium-rich brines. The widespread existence of dedolomite to depths of $650 \mathrm{ft}$ on the freshwater side of the freshwater/saline-water transition zone, coupled with its absence on the saline-water side, is evidence that dedolomitization in the fault zone took place since the Balcones faulting initiated conditions that ultimately produced the Edwards aquifer. Most dedolomite in the Edwards aquifer probably formed during the last 15 to 20 million years (R.W. Maclay, U.S. Geological Survey, written commun., 1990). 
TABLE 2.-Approximate maximum thickness of lithostratigraphic units that compose the Edwards-Trinity aquifer system, westcentral Texas

\begin{tabular}{|c|c|c|}
\hline Lithostratigraphic unit & $\begin{array}{l}\text { Thickness } \\
\text { (feet) }\end{array}$ & Source of thickness data \\
\hline Navarro Group & 500 & Maclay and Small, 1986, table 1 \\
\hline 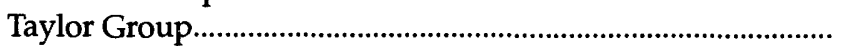 & 500 & 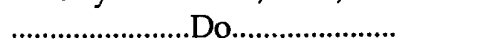 \\
\hline Austin Group & 350 & 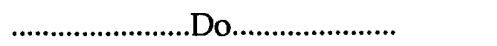 \\
\hline 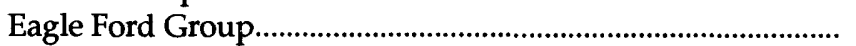 & 250 & 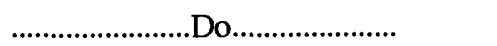 \\
\hline Buda Limestone & 200 & Small and Ozuna, 1993, table 1 \\
\hline 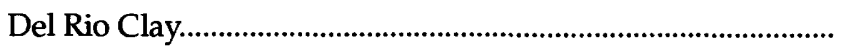 & 170 & C.I. Smith, written commun., 1989 \\
\hline 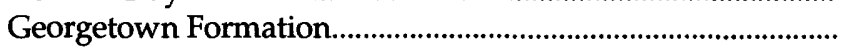 & 60 & Rose, 1972, fig. 16 \\
\hline 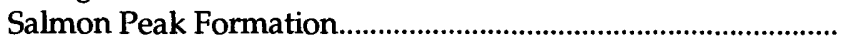 & 500 & Humphreys, 1984, fig. 2 \\
\hline 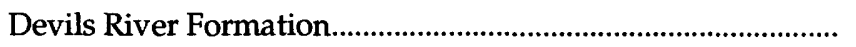 & 700 & Maclay and Small, 1986, table 1 \\
\hline Boracho Formation & 410 & Brand and Deford, 1958, fig. 2 \\
\hline 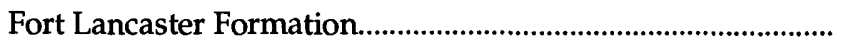 & 405 & C.I. Smith, written commun., 1989 \\
\hline Segovia Formation & 380 & Rose, 1972, fig. 23 \\
\hline Person Formation & 260 & Rose, 1972, fig. 15 \\
\hline 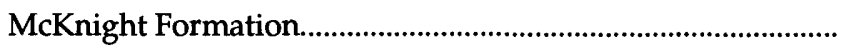 & 285 & Carr, 1987, p. 21 \\
\hline 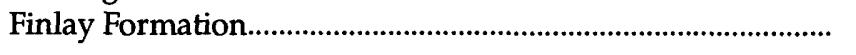 & 165 & Small and Ozuna, 1993, table 1 \\
\hline Fort Terrett Formation & 300 & Rose, 1972, fig. 21 \\
\hline 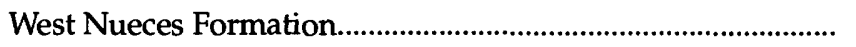 & 260 & Miller, 1984, p. 9 \\
\hline Kainer Formation & 400 & Rose, 1972, fig. 14 \\
\hline Maxon Sand & 200 & C.I. Smith, written commun., 1989 \\
\hline 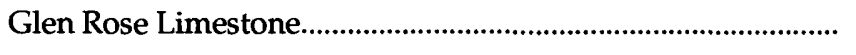 & 1,530 & Welder and Reeves, 1964, table 1 \\
\hline 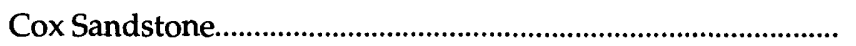 & 170 & Brand and Deford, 1958, fig. 2 \\
\hline Yearwood Formation & 180 & 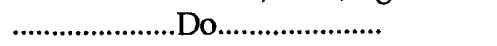 \\
\hline 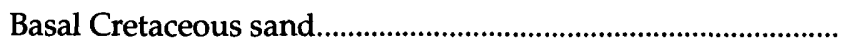 & 395 & Romanak, 1988, p. 21; Wessel, 1988 \\
\hline \multicolumn{3}{|l|}{ Hensel Sand/Bexar Shale } \\
\hline 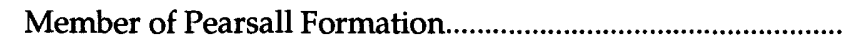 & 210 & Imlay, 1945, table 2 \\
\hline \multicolumn{3}{|l|}{ Cow Creek Limestone/Cow Creek Limestone } \\
\hline 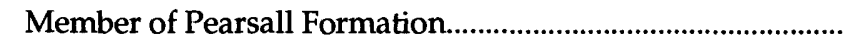 & 88 & 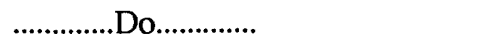 \\
\hline \multicolumn{3}{|l|}{ Hammett Shale/Pine Island Shale } \\
\hline Member of Pearsall Formation & 130 & Amsbury, 1974, fig. 12 \\
\hline 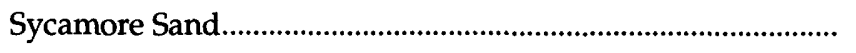 & 50 & DeCook, 1963, table 3 \\
\hline Sligo Formation & 240 & Imlay, 1945, table 2 \\
\hline Hosston Formation & 880 & 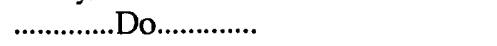 \\
\hline
\end{tabular}

\section{STRATIGRAPHIC CONDITIONS}

The geology of west-central Texas has been studied extensively by the petroleum industry, academic institutions, and government agencies. Several correlation charts, reflecting different interpretations by different workers, are published for strata that compose the Edwards-Trinity aquifer system.

The Cretaceous nomenclature of west-central Texas was synthesized for plate 1 from several publications. By combining the pertinent chronostratigraphic and lithostratigraphic nomenclature with aquifer and confining unit terminology, plate 1 summarizes the relation between stratigraphy and ground-water hydrology in the RASA study area (fig. 1). Because the correlation chart was compiled from several sources, the stratigraphic names do not necessarily conform to current usage of the U.S. Geological Survey. The aquifer names (except for the High Plains aquifer of Weeks and others (1988)) were adopted from the Texas Water Plan (Texas Water Development Board, 1990, p. 1-5 and 1-6). The approximate maximum thicknesses of the lithostratigraphic units that compose the Edwards-Trinity aquifer system are shown in table 2. 
Hydrogeologic sections through various parts of the study area show the vertical distribution of strata that contain the aquifers and confining units of the Edwards-Trinity aquifer system (pls. 2-8). The sections primarily are based on interpretation of borehole geophysical (electric) logs that were purchased from the Petroleum Information Corp. The locations of the 65 wells from which the borehole data were taken are shown in figure 15. Most of the stratigraphic contacts shown on the sections were interpreted from resistivity, spontaneous potential, and natural gamma ray logs that primarily were obtained from hydrocarbon exploration wells. A tracing of each electric log used for control is reproduced on the sections, and each well is described above the appropriate tracing(s). The descriptions cite (from top to bottom) the well operator name, lease or well name, well number, and altitude of land surface. The depth of the well, if known, is given below each tracing. The stratigraphic contacts interpreted from the electric logs are supplemented on the hydrogeologic sections with published stratigraphic and structural data from reports cited in the text.

\section{ROCKS OF TRINITIAN AGE}

The correlation of the Trinity strata (pl. 1) primarily is based on descriptions by Forgotson (1956), Lozo and Stricklin (1956, fig. 4), Brand and Deford (1958, fig. 2), Loucks (1977, fig. 4), and Smith and Brown (1983, fig. 3). The lateral and vertical distributions of the Trinity strata are summarized in figures 8 and 9, respectively.

Sediments in the Trinity outcrop between the top of Paleozoic rocks and the base of the Glen Rose Limestone were originally called the Travis Peak Formation (Taff, 1892; Hill and Vaughan, 1898; and Hill, 1901). After finding key disconformities and an additional shale unit within the original Travis Peak Formation, Lozo and Stricklin (1956) raised each member of the Travis Peak sequence to formational rank, and recommended that Travis Peak nomenclature be "*** deleted from modern stratigraphic terminology or reserved for use by laymen." However, in recognition of usage that continues locally, the term Travis Peak equivalent is applied in this report to the outcrop and shallow subcrop of Trinity strata in the Hill Country to represent the combined Sycamore Sand, Hammett Shale, Cow Creek Limestone, and Hensel Sand (pl. 1).

The Pearsall Formation was defined by Imlay (1945, p. 1,441) to include sediments above the Sligo Formation and below the Glen Rose Limestone that represent the subsurface equivalents of what at that time (1945) was recognized as the Travis Peak Formation of the outcrop (Taff, 1892; Hill and Vaughan, 1898; and Hill, 1901). The Pearsall Formation is applied in this report to the subcrop of Trinity strata in the Balcones fault zone where it contains the Pine Island Shale, Cow Creek Limestone, and Bexar Shale Members (pl. 1) and to the south-central part of Edwards County, where the formation is not differentiated into members (fig. 8).

The Hosston Formation typically is a siliciclastic siltstone and sandstone lithofacies in updip areas and a dolomitic mudstone and grainstone lithofacies in downdip areas. The downdip dolomitic sediments grade upward into evaporites and intertidal limestone and dolostone of the Sligo Formation (Bebout and others, 1981). From a shallow-marine carbonate lithofacies in downdip areas, the Sligo Formation grades updip, toward the Llano uplift (fig. 8), into the terrigenous clastic lithology of the Hosston Formation (fig. 9). Farther updip, the Hosston Formation grades into the Sycamore Sand (Lozo and Smith, 1964) of the outcrop area. The Sycamore Sand is a clastic unit composed predominately of quartzose sand and gravel, with some feldspathic and dolomitic detritus (Amsbury, 1974, p. 6).

The Hammett Shale (Lozo and Stricklin, 1956) in the Hill Country has the same stratigraphic position as the genetically similar Pine Island Shale Member of the Pearsall Formation (Forgotson, 1956) in the Balcones fault zone (pl. 1); the different nomenclature reflects the preferred usage in each area (Murray, 1961, p. 308-309). The Pine Island Shale Member extends eastward from the Balcones fault zone and is one of the most persistent Lower Cretaceous rock units in east Texas. The updip Hammett Shale typically is a burrowed mixture of clay, terrigenous silt, carbonate mud, silt-sized dolomite, and carbonate particles (Amsbury, 1974). The downdip Pine Island Shale Member primarily is a gray to black ("splintery") calcareous shale interbedded with dense gray limestone (Forgotson, 1957). The Hammett Shale and Pine Island Shale lithostrome interfingers vertically with the overlying Cow Creek Limestone and Cow Creek Limestone Member.

The largely bioclastic Cow Creek Limestone (Lozo and Stricklin, 1956) mostly is a regressive beach sequence on the southern flank of the Llano uplift (Stricklin and Smith, 1973). The lower part of the Cow Creek Limestone generally is a fine- to coarsegrained calcarenitic limestone, with large oyster fragments. The middle part is a silty calcarenite, containing carbonate concretions and fine quartz sand. The upper part is a crossbedded beach coquina, composed primarily of oyster-shell detritus, poorly sorted quartz grains, and scattered chert pebbles. The updip Cow Creek Limestone is overlain by the Hensel Sand, and the downdip Cow Creek Limestone Member of the Pearsall Formation (Forgotson, 1956) is overlain by the Bexar Shale Member (fig. 9, $\mathrm{H}-\mathrm{H}^{\prime}$ ). 


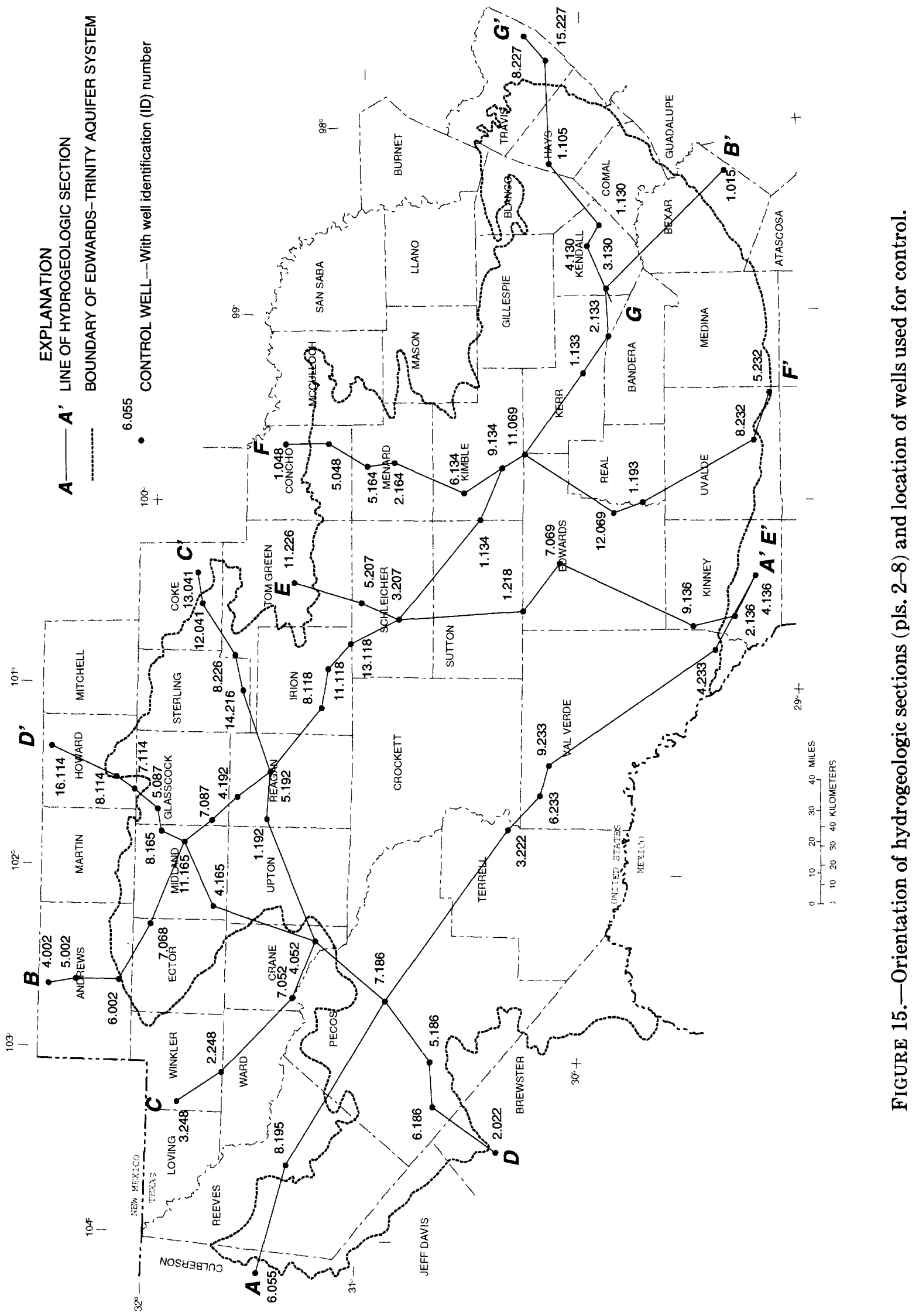


The Bexar Shale Member of the Pearsall Formation (Forgotson, 1956) typically is a mixture of dark mudstone, clay, and shale. The name is derived from Bexar County, where the unit is particularly distinct on electric logs (Forgotson, 1957, p. 2,347). In this report, the Bexar Shale Member applies to the gray to black calcareous shale with intermixed thin, dense, finely crystalline beds of limestone between the Cow Creek Limestone Member and Glen Rose Limestone throughout the Balcones fault zone (pl. 1). The Bexar Shale Member has been interpreted as the fine-grained, marine equivalent of the near-shore, terrigenous lithofacies of the Hensel Sand (Loucks, 1977, p. 106).

The Hensel Sand (Lozo and Stricklin, 1956) comprises a weakly cemented mixture of ferruginous clay, quartz and calcareous sand (crossbedded in places), and chert and dolomite pebbles, which typically form a basal conglomerate (Inden, 1974). The clastic sediments of this time-transgressive unit weather to a distinctive nonuniform rusty-yellow appearance. Downdip parts of the Hensel Sand on the western flank of the Llano uplift (fig. 9, $J-J^{\prime}$ ) grade northwestward into the genetically similar basal Cretaceous sand. Updip parts of the Hensel Sand on the southern flank of the Llano uplift (fig. 9, $H-H^{\prime}$ ) have been interpreted as the clastic, shoreward equivalent of the Glen Rose Limestone (Stricklin and others, 1971).

The Glen Rose Limestone (Lozo and Stricklin, 1956) is a sandy, fossiliferous limestone and dolostone unit, characterized by repetitious interbeds of calcareous marl, clay, and shale and laterally persistent stringers of gypsum and anhydrite. The (informal) lower member of the Glen Rose Limestone comprises mostly mediumthick beds of limestone, dolostone, and dolomitic limestone with diverse mollusk assemblages and locally distributed rudist reefs (Perkins, 1974). The (informal) upper member of the Glen Rose predominately is a thin- to medium-bedded sequence of nonresistant marls alternating with resistant beds of dolostone, mudstone, and bioclastic limestone (Stricklin and others, 1971). Reef structures mostly occur in the southeastern part of the Hill Country within uppermost intervals of the lower member (Perkins, 1974, p. 131-171). Characteristically, the upper member contains no evidence of reef formation and one or more evaporite stringers. The alternating lithology of the different interbeds within middle and upper parts of the Glen Rose Limestone imparts an uneven resistance to erosion, which renders a stairlike topographic profile to much of the Hill Country.

The calcareous, shallow-marine lithology of the Glen Rose Limestone grades northward into a quartzose clastic, terrestrial lithology of the Hensel Sand in the eastern part of the study area and the basal Cretaceous sand in the western part (fig. 8). The location of this carbonate-to-clastic facies transition, known as the Glen Rose pinchout, is approximated in figure 8 by the zigzag pattern between northern Blanco and southern Pecos Counties. In the southern parts of the Edwards Plateau and Trans-Pecos, the Glen Rose Limestone generally is overlain by the Maxon Sand.

The Maxon Sand (King, 1980, p. 21) predominately is a brownish, well indurated, coarse- to medium-grained, crossbedded sandstone, with lesser amounts of conglomerate, mudstone, and limestone (Butterworth, 1970, p. 4). The sandstone mainly is composed of quartz with minor amounts of feldspar and heavy minerals eroded from Permian and Triassic rocks northwest of the study area. The constituents generally are consolidated with calcite, hematite, and kaolinite cements. The Maxon Sand forms conspicuous ledges atop the Glen Rose Limestone where these units crop out along escarpments east of the Marathon uplift in northeastern Brewster and southern Pecos Counties (fig. 8). From Terrell County eastward, the Maxon Sand mostly is buried beneath the Fort Terrett Formation.

The (informal) basal Cretaceous sand (Smith and Brown, 1983) is the sole Trinity rock unit in the northern part of the study area (fig. 8, pl. 1). The basal Cretaceous sand underlies the updip wedge of Glen Rose Limestone in southwestern parts of the study area, where the sand is stratigraphically equivalent to the Hosston Formation, Hammett Shale, Cow Creek Limestone, and Hensel Sand (fig. $9, J-J^{\prime}$ ). North of the updip limit of the Glen Rose Limestone, the basal Cretaceous sand underlies either the Finlay or Fort Terrett Formations of Fredericksburgian age and includes sediments equivalent to the Maxon Sand. The basal Cretaceous sand of this report includes the "basement sands," "Trinity sand," and "basal Cretaceous sandstone" of previous reports, and it incorporates the Yearwood Formation and Cox Sandstone of Brand and Deford (1958).

The basal Cretaceous sand generally is observed as varying mixtures of sandstone, siltstone, and conglomerate. The major constituents are well-rounded fragments of quartz, chert, and feldspar derived from Permian and Triassic red beds. Calcite is the dominant cement, but dolomite, ankerite, silica, kaolinite, and hematite are prevalent locally (Romanak, 1988, p. 27). This diverse, areally extensive deposit generally is unfossiliferous and varies both vertically and laterally in color, texture, composition, and degree of cementation. The lower part of the unit generally is coarse grained; a fine- to medium-grained sandstone replaces a basal conglomerate in places. A finer grained, variegated middle section is crossbedded in places and indurated locally with calcareous cement. Upper parts of the 
unit might include small amounts of limestone and thin, calcareous shale interbeds.

\section{ROCKS OF FREDERICKSBURGIAN AND WASHITAN AGES}

The correlation of the Fredericksburg and Washita strata (pl. 1) primarily is based on descriptions by Brand and Deford (1958), Lozo and Smith (1964), Rose (1972), and Smith and Brown (1983). The correlation chart relates (1) the Edwards Group of Rose (1972) in the northeastern part of the Balcones fault zone and eastern part of the Edwards Plateau; (2) the Devils River, West Nueces, McKnight, and Salmon Peak Formations of Lozo and Smith (1964) in the southwestern part of the Balcones fault zone and south-central part of the Edwards Plateau; (3) the Finlay and Boracho Formations of Brand and Deford (1958) in the northwestern part of the Trans-Pecos and western part of the Edwards Plateau; and (4) the Fort Terrett and Fort Lancaster Formations of Smith and Brown (1983) in the southeastern part of the Trans-Pecos and north-central part of the Edwards Plateau. The lateral and vertical distributions of the Fredericksburg and lower Washita strata are summarized in figures 11 and 12, respectively.

The Edwards Group of Rose (1972) includes all of the Fredericksburg strata and the lower part of the Washita strata in the northeastern part of the Balcones fault zone and in the eastern part of the Edwards Plateau. In the northeastern part of the Balcones fault zone, the Edwards Group consists of the Kainer and Person Formations. In the eastern part of the Edwards Plateau, the Edwards Group consists of the Fort Terrett and Segovia Formations.

Across the western part of the Balcones fault zone, the southwestern part of the Hill Country, and the southern part of the Edwards Plateau, the Kainer, Person, Fort Terrett, Segovia, and Fort Lancaster rock sequences lose their identities against the Devils River trend, a narrow, semioval carbonate bank (figs. 11, 12, $L-L^{\prime}$ ). The Devils River trend (fig. 6) bounds the northern part of the Maverick basin (Winter, 1962), which also is bound by the Stuart City reef trend on the south and by the San Marcos arch on the east. The Devils River trend, represented stratigraphically by the Devils River Formation (Miller, 1984), is a composite of dolostone, fossiliferous limestone, and reef debris (Lozo and Smith, 1964, p. 290-296). The lower part of the Devils River Formation is stratigraphically continuous with the lower, dolomitic part of the Fort Terrett Formation. However, because the Devils River Formation is relatively homogeneous from top to bottom, it is impractical to subdivide this formation, except to recognize the informal lower (dolomitic) and upper (limestone) parts.
The Fredericksburg and lower Washita rock units of the Maverick basin (Lozo and Smith, 1964) are the West Nueces, McKnight, and Salmon Peak Formations. The West Nueces Formation is a transgressive lithofacies that closely resembles the nodular shell-fragment limestone at the base of the Fort Terrett Formation and in lower parts of the Devils River Formation (Smith, 1979, p. 15). According to Maclay and Small (1983, p. 132), the McKnight Formation predominately is a euxinic deposit that "*** grades upward from thinbedded carbonate mudstones to petroliferous shales and evaporites and terminates in a layer of pelleted grainstones." The Salmon Peak Formation (Humphreys, 1984) predominately is a dense, thick-bedded, deepwater mudstone that grades upward to a crossbedded, rudist-shell grainstone (Smith, 1979, p. 16).

Smith and Brown (1983) extended the Fort Terrett Formation (Rose, 1972) to include Fredericksburg strata in the central and western parts of the Edwards Plateau and in most of eastern Pecos and Terrell Counties of the Trans-Pecos (fig. 11). The Fort Terrett Formation shows strong lateral continuity, featuring a basal transgressive unit overlain by a distinctive burrowed zone, in turn overlain by thin- to medium-bedded bioclastic limestone and dolomitic strata. Although the effects of dolomitization and neomorphic alteration within the formation are prevalent in the eastern part of the Edwards Plateau (Rose, 1972, p. 29-46), they are much less common in the western part. Interbedded gypsum of the "Kirschberg evaporite zone," or a collapse breccia resulting from dissolution of the gypsum, is most common in the northeastern part of the Edwards Plateau.

The Fort Terrett Formation grades into the Finlay Formation (Brand and Deford, 1958) near the western limits of the study area, where the Finlay Formation unconformably overlies the basal Cretaceous sand of Trinitian age (figs. 11, 12, K-K'). The Finlay Formation is composed mostly of gray, massive to thick-bedded, cherty and marly limestone, with interbeds of gray to brown quartz sandstone and shale near the base and thin- to thick-bedded fossiliferous limestone near the top (Reaser and Malott, 1985). The Fort Terrett Formation grades southward through the Big Bend area of Texas (fig. 3) into the Telephone Canyon and Del Carmen Formations (figs. 11, 12, M-M') of northern Mexico (Smith, 1970).

The Boracho Formation unconformably overlies the Finlay Formation and includes all of the Fredericksburg and Washita strata between the Finlay Formation and the Del Rio Clay, or the Buda Limestone where the Del Rio Clay is absent. The Boracho Formation (Brand and Deford, 1958) characteristically is limestone and marl, with a dominantly marly lower part. The upper part mostly is composed of massive, argillaceous limestone 
that typically forms a steep slope below a caprock of Buda Limestone.

The Fort Lancaster Formation (Smith and Brown, 1983), composed of uppermost Fredericksburg and lowermost Washita strata in the north-central part of the Edwards Plateau and eastern part of the Trans-Pecos, is equivalent to the Segovia Formation on the east and the Boracho Formation on the west (figs. 11, 12, K-K'). The Fort Lancaster Formation was deposited mostly in open shallow-marine to open-shelf environments (Scott and Kidson, 1977, p. 174) on the southwestern flank of the central Texas platform in water that deepened toward the Fort Stockton basin (figs. 6, 10). Relatively thick-bedded, rudist-bearing limestone helps distinguish eastern parts of the Fort Lancaster Formation from the generally thinner-bedded dolostone and dolomitic limestone of the Segovia Formation that formed concurrently in intertidal and restricted shallow-marine environments atop the central Texas platform. The Fort Lancaster Formation thickens toward the west and south and shows a decreasing density of rudists and of miliolid and shell-fragment grainstones toward the west and north, with an increasing incidence of ammonites, pelecypods, and marly sediments (C.I. Smith, University of Texas at Arlington, oral commun., 1989). The Fort Lancaster Formation grades southward through the Big Bend area of Texas into the Sue Peaks and Santa Elena Formations (figs. 11, 12, M-M') of northern Mexico (Smith, 1970).

The marly, nodular limestone that composes basal parts of the Fort Lancaster and Sue Peaks Formations erodes to a distinctive, grass-covered slope over much of the Edwards Plateau and Trans-Pecos (Smith and Brown, 1983, p. 19). The outcrop characteristics of this ammonite-bearing horizon have helped geologists map the Fredericksburgian-Washitan boundary in the field for more than 100 years.

The Del Rio Clay on the San Marcos arch consists of bluish-gray, calcareous clay and gypsiferous silt and shale, with abundant marine megafossils and pyrite (University of Texas, Bureau of Economic Geology, 1983). In the eastern part of the Edwards Plateau, the Del Rio Clay typically is a yellowish-brown, poorly indurated calcareous clay that in places contains thin reddish-brown silty streaks and coquinoid lenses of small oysters (Rose, 1972, p. 43). In the Trans-Pecos and western part of the Edwards Plateau, the unit is fossiliferous locally-containing some ammonites-and mostly consists of interbedded, thin, calcareous and siliceous flagstones and marly limestone (Adkins, 1933, p. 388-396). The Del Rio Clay almost everywhere contains pyrite that typically weathers to limonite and characteristically renders a rusty-yellow outcrop. From a maximum thickness of about $170 \mathrm{ft}$ near the town of
Del Rio (fig. 11), the formation thins in all directions-but most sharply toward the north, where it occurs mainly as scattered, thin remnants atop the Edwards Plateau.

The Buda Limestone on the San Marcos arch is a light gray, porcellaneous limestone with pelagic foraminifera, fragile mollusk fragments, and microspherulites (Rose, 1972, p. 27). In the eastern part of the Edwards Plateau, this open-shelf limestone consists of nodular micrite, mollusk-fragment biomicrite, and marly interbeds (Rose, 1972, p. 43). In the Trans-Pecos and western part of the Edwards Plateau-where the unit typically is exposed as a light gray to white caprock on mesas that characterize the recently uplifted landscape-the Buda Limestone is slightly argillaceous, locally crossbedded, and extremely hard (Brand and Deford, 1958, p. 385). Whereas fractured surfaces of Buda Limestone generally are hackly or conchoidal, weathered surfaces typically cast a nodular appearance.

\section{ROGKS OF EAGLEFORDIAN THROUGH NAVARROAN AGES}

The Del Rio Clay and Buda Limestone of Washitan age (Comanchean Series) are overlain in the Balcones fault zone by Eagle Ford, Austin, Taylor, and Navarro sediments of the Gulfian Series (pl. 1). The Eagle FordNavarro rock sequence is thickest in the Balcones fault zone where it forms the bulk of the Navarro-Del Rio confining unit. Collectively, the contributing units range from more than 1,200 to nearly 2,000 ft thick (table 2). The Eagle Ford, Austin, Taylor, and Navarro Groups consist primarily of interbedded shale, siltstone, limestone, chalk, and marl (University of Texas, Bureau of Economic Geology, 1974a; 1983).

\section{EDWARDS-TRINITY AQUIFER SYSTEM}

The Cretaceous strata of the study area thicken from less than $1,000 \mathrm{ft}$ thick in the area of outcrop and shallow subcrop (fig. 4) to more than $10,000 \mathrm{ft}$ thick near the ancestral shelf edge (McFarlan, 1977, p. 5). The Edwards-Trinity aquifer system is within the updip, western part of this sediment wedge. Terrigenous clastic and terrestrial deposits of early Trinitian age grade upward into supratidal and intertidal evaporitic and dolomitic rocks and shallow-marine, lagoonal, and basinal carbonate strata of late Trinitian, Fredericksburgian, and Washitan age. A thick, downfaulted remnant of mostly open-shelf sediments of Eaglefordian through Navarroan age confines a small, southeastern part of the aquifer system. The relation between the stratigraphic and hydrogeologic units that compose the Edwards-Trinity aquifer system is summarized on plate 1. 
The Cretaceous strata of the Edwards-Trinity aquifer system ( $\mathrm{pl} .1$ ) are divided regionally into three aquifers and two confining units (fig. 2). The aquifers, from east to west and top to bottom, are (1) the Edwards aquifer in the Balcones fault zone; (2) the Trinity aquifer in the Balcones fault zone and Hill Country; and (3) the Edwards-Trinity aquifer in the Edwards Plateau and Trans-Pecos. The Navarro-Del Rio confining unit extends over about 70 percent of the Balcones fault zone, and the Hammett confining unit is present beneath about 80 percent of the Hill Country and less than 10 percent of the Edwards Plateau.

These aquifer and confining-unit divisions are based on regional contrasts in hydraulic conductivity that determine the relative capacity of the different rock units to transmit ground water over tens of square miles. The hydraulic conductivity of the strata was inferred largely from aquifer-test and specific-capacity data and an inherent, general relation between the stratigraphy and hydraulic conductivity. The aquifertest and specific-capacity data were obtained mainly from Walker (1979), Rees and Buckner (1980), Ashworth (1983), Baker and others (1986), and Maclay and Small (1986). A general relation between the stratigraphy and the hydraulic conductivity exists because the stratigraphy reflects the spatial distribution of the individual rock units, and each rock unit resulted from a unique combination of depositional, tectonic, and diagenetic conditions. These same conditions control the distribution of hydraulic conductivity. Therefore, the hydraulic conductivity of strata for which hydraulic data were not available was estimated from the relation between stratigraphy and hydraulic conductivity where data are available to infer that relation.

The regional aquifers comprise strata that mainly are permeable as the result of fractures, joint cavities, and porosity caused by the dissolution of evaporites and relatively unstable carbonate constituents. The confining units comprise comparatively impermeable strata that are continuous over more than $100 \mathrm{mi}^{2}$ and affect regional patterns of ground-water circulation. The confining units mostly are calcareous mudstone, siltstone, and shale of low-energy terrigenous and open-shelf environments. Because of the regional scope of the RASA study and the need to generalize from sitespecific data, the aquifers include some confining strata and the confining units contain some strata permeable enough to supply small amounts of water to a few wells in limited areas.

\section{HYDRAULIC GHARACTERISTICS}

\section{POTENTIOMETRIC SURFACE}

The regional distribution of hydraulic head in the Edwards-Trinity aquifer system under long-term average, near-predevelopment (historical) conditions is shown in figure 16. The potentiometric-surface map is based on water levels measured in nearly 1,800 wells between 1915-69 (Bush and others, 1993). Because pumpage was negligible when most of the water levels were measured, the potentiometric-surface data represent predevelopment or near predevelopment conditions in most areas. However, water levels in Bexar, Reeves, Pecos, Reagan, and Upton Counties might reflect the effects of minor ground-water development.

The most important controls on hydraulic head in the Edwards-Trinity aquifer system are the slope on the base of the aquifer system (fig. 7), topographic relief (fig. 3), and the location of springs and streams (fig. 3). The base of the aquifer system (Barker and Ardis, 1992) generally slopes from northwest to southeast, and this is the prevailing direction of ground-water flow as indicated by the potentiometric contours in figure 16. The altitude of land surface decreases about 2,500 ft from northwest to southeast, and the potentiometric surface typically is a subdued replica of the associated topography. The strong influence of springs and streams on the shape of the potentiometric surface indicates that the distribution of hydraulic head and the direction of ground-water flow largely are controlled by the areas of ground-water discharge.

The hydraulic heads used to construct the potentiometric map (Bush and others, 1993) range from nearly $800 \mathrm{ft}$ below land surface in Terrell County to nearly 100 $\mathrm{ft}$ above land surface in Bexar County. Most of the water levels are within $200 \mathrm{ft}$ of land surface, except in the central part of the aquifer system where they mostly range from 200 to $400 \mathrm{ft}$ below land surface. Although the topographic influences on hydraulic head generally are most obvious in the lower-lying areas of relatively shallow ground water, the potentiometric surface is graded in places toward the Colorado River, Pecos River, and Rio Grande-all major drains that are incised deeply into the rocks that form the Edwards-Trinity aquifer.

Except where the aquifer system is anisotropic, the flow of ground water is normal to the potentiometric contours (fig. 16). Thus, the prevailing direction of flow in the study area is toward major springs and perennial streams (fig. 3). The influence of the three largest streams - the Colorado River, the Pecos River, and the Rio Grande - is apparent over most of the Hill Country, Edwards Plateau, and Trans-Pecos from the steep 


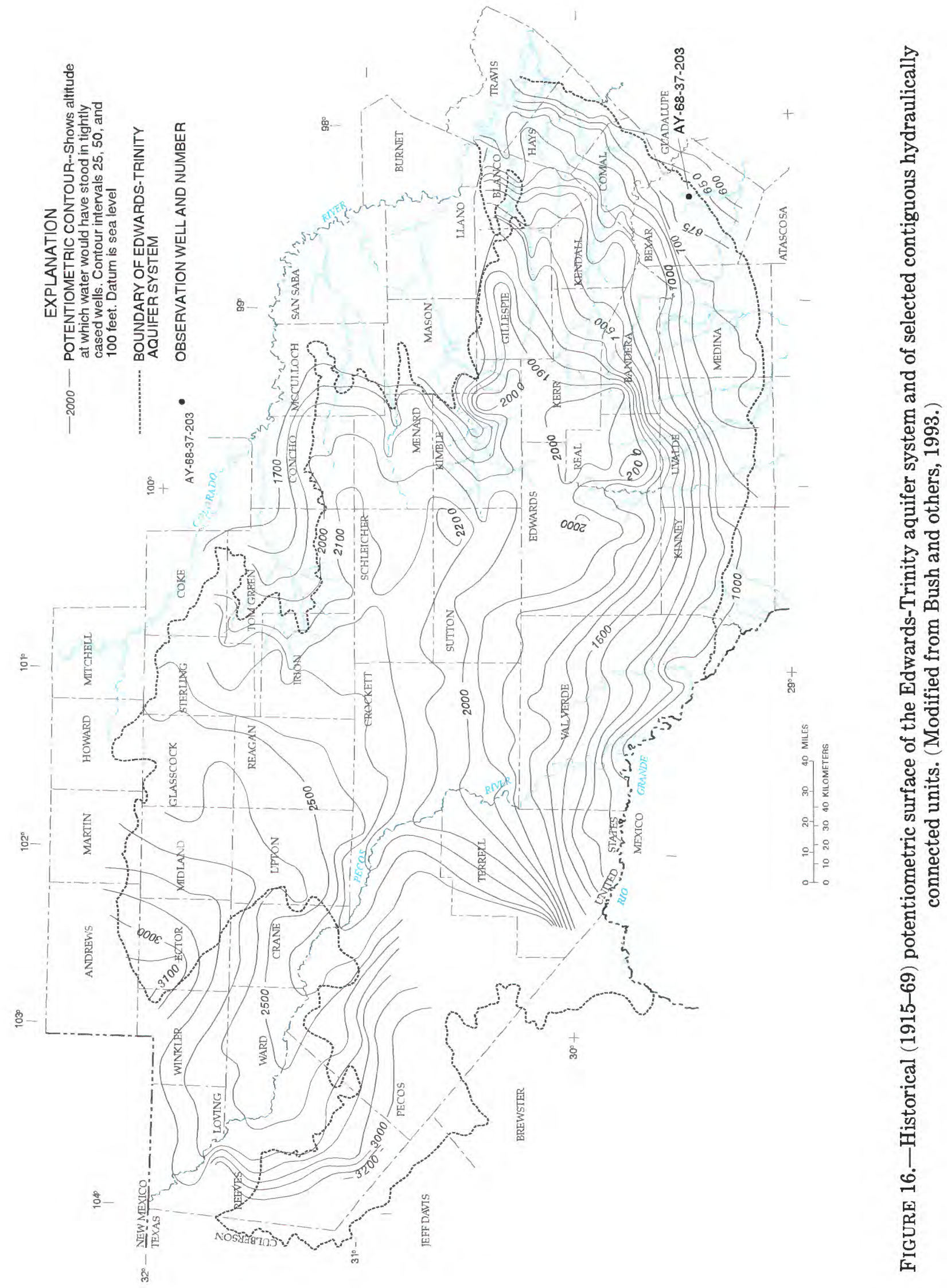


hydraulic gradients toward these regional drains. The potentiometric contours sweep upstream where the streams draining eastern and southern margins of the Edwards Plateau are sustained largely by base flow.

The en echelon geologic structure and the resulting distribution of transmissivity in the Balcones fault zone make the regional potentiometric-surface map (fig. 16) a misleading indicator of the direction of most groundwater flow in large parts of the Edwards aquifer (Arnow, 1963, p. 29-30). The regional potentiometric contours indicate that under typical, isotropic conditions most of the ground water should flow southeastward toward the freshwater/saline-water transition zone. However, many of the Balcones faults (fig. 6) are barrier faults, which impede or block the southeastward flow of ground water, so that most of the water is diverted northeastward (Maclay and Small, 1986, p. 39). The fracture network, as well as the associated joint cavities and solution channels that are subparallel to the barrier faults, impart an anisotropic pattern of hydraulic conductivity and a dominant southwest-tonortheast component of transmissivity. Although the southwest-to-northeast gradients are comparatively small, the transmissivity tensors aligned with the fault zone are great enough to move large amounts of ground water from recharge areas in the southwestern part of the fault zone to major springs in the northeastern part (figs. 3,4 ).

\section{SATURATED THICKNESS}

The saturated thickness of the Edwards-Trinity aquifer system under long-term average, near predevelopment (historical) conditions is shown in figure 17. The saturated thickness, which generally is more than $500 \mathrm{ft}$ in the southern part of the aquifer system, typically decreases to less than $100 \mathrm{ft}$ near the northern limits of the study area. The saturated thickness is more than $500 \mathrm{ft}$ throughout the Balcones fault zone and over the southeastern two-thirds of the Hill Country. The saturated thickness decreases to less than $100 \mathrm{ft}$ over the northwestern third of the Hill Country where the Trinity aquifer thins against Precambrian rocks of the Llano uplift. In the Edwards Plateau, the saturated thickness grades from more than $500 \mathrm{ft}$ in the southern one-half of the area to less than $100 \mathrm{ft}$ along the northern margin. In the Trans-Pecos, the saturated thickness varies over short distances from more than $500 \mathrm{ft}$ to less than $100 \mathrm{ft}$, reflecting rugged relief on the base of the aquifer system and contiguous hydraulically connected units.

Local variations from the regional patterns of saturated thickness result from structural troughs and ridges on the base of the aquifer system (Barker and Ardis, 1992). Subregional increases in saturated thick- ness in parts of Kimble, Sutton, and Terrell Counties result from northwest-to-southeast plunging troughs in the pre-Cretaceous rocks that form the base of the aquifer system. A ridge of Permian rock extending southward from southwestern Concho County, through western Menard County, to northwestern Kimble County is responsible for a conspicuous, lobate-shaped pattern of less than 100-ft saturated thickness across this area.

Just as topographic highs and lows (fig. 3) produce highs and lows in the potentiometric surface (fig. 16), the relief in the potentiometric surface affects the distribution of saturated thickness (fig. 17). Areas of lesser saturated thickness associated with areas of lower hydraulic head are present throughout the study area; however, such areas are especially prominent in the Hill Country and along the northeastern margin of the Edwards Plateau. The relation is evident mostly along the upper reaches of the Concho, San Saba, Llano, Pedernales, Blanco, and Guadalupe Rivers.

The map of saturated thickness (fig. 17) extends beyond the boundary of the Edwards-Trinity aquifer system in parts of Crane, Pecos, Reeves, Upton, and Ward Counties. Here, the map depicts the saturated thickness of the Cenozoic Pecos alluvium aquifer (Ashworth, 1990, p. 12), which is connected hydraulically to the Edwards-Trinity aquifer in those counties.

In western parts of the Edwards Plateau and in the Trans-Pecos, the Edwards-Trinity aquifer is underlain by the Dockum aquifer (Ashworth, 1990, p. 6; Texas Water Development Board, 1990, fig. 1-2). Where the Edwards-Trinity aquifer overlies the Dockum aquifer (fig. 2), the saturated thickness of the regional groundwater-flow system might be considered from 100 to $200 \mathrm{ft}$ greater than that shown in figure 17 for the Edwards-Trinity aquifer alone.

\section{TRANSMISSIVITY}

Transmissivity equals the product of hydraulic conductivity and saturated thickness, both of which vary spatially. Saturated thickness also can vary with time as a result of seasonal or long-term changes in hydraulic head. Although hydraulic conductivity varies greatly as a function of direction inside the Balcones fault zone, hydraulic conductivity typically is small outside the fault zone. Although saturated thickness is uniformly large inside the fault zone, it varies greatly outside the fault zone.

The regional distribution of transmissivity in the Edwards-Trinity aquifer system (fig. 18) was ascertained from the results of aquifer tests, geologic observation, and computer simulation. First, estimates of transmissivity from the results of 29 aquifer tests (based 


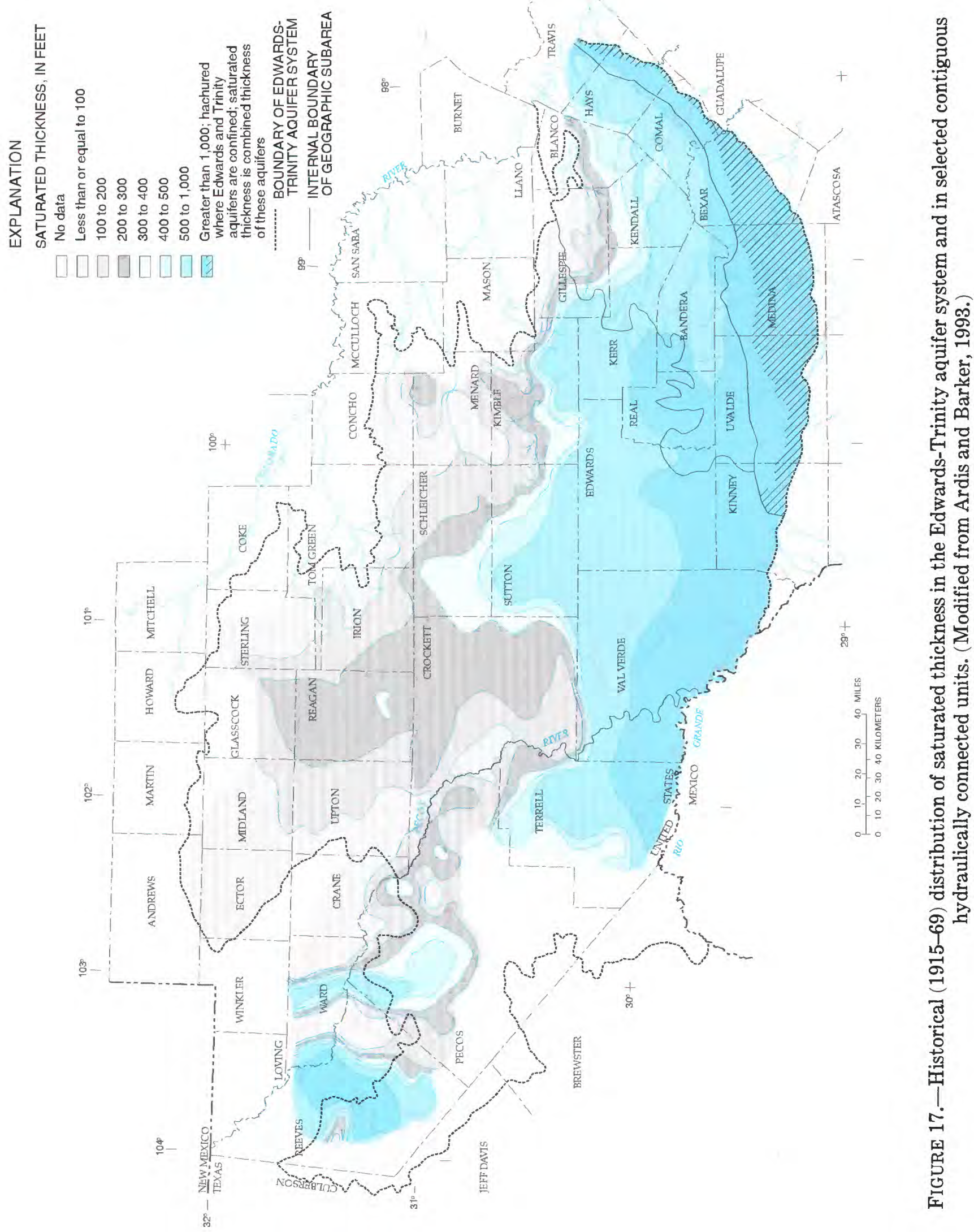




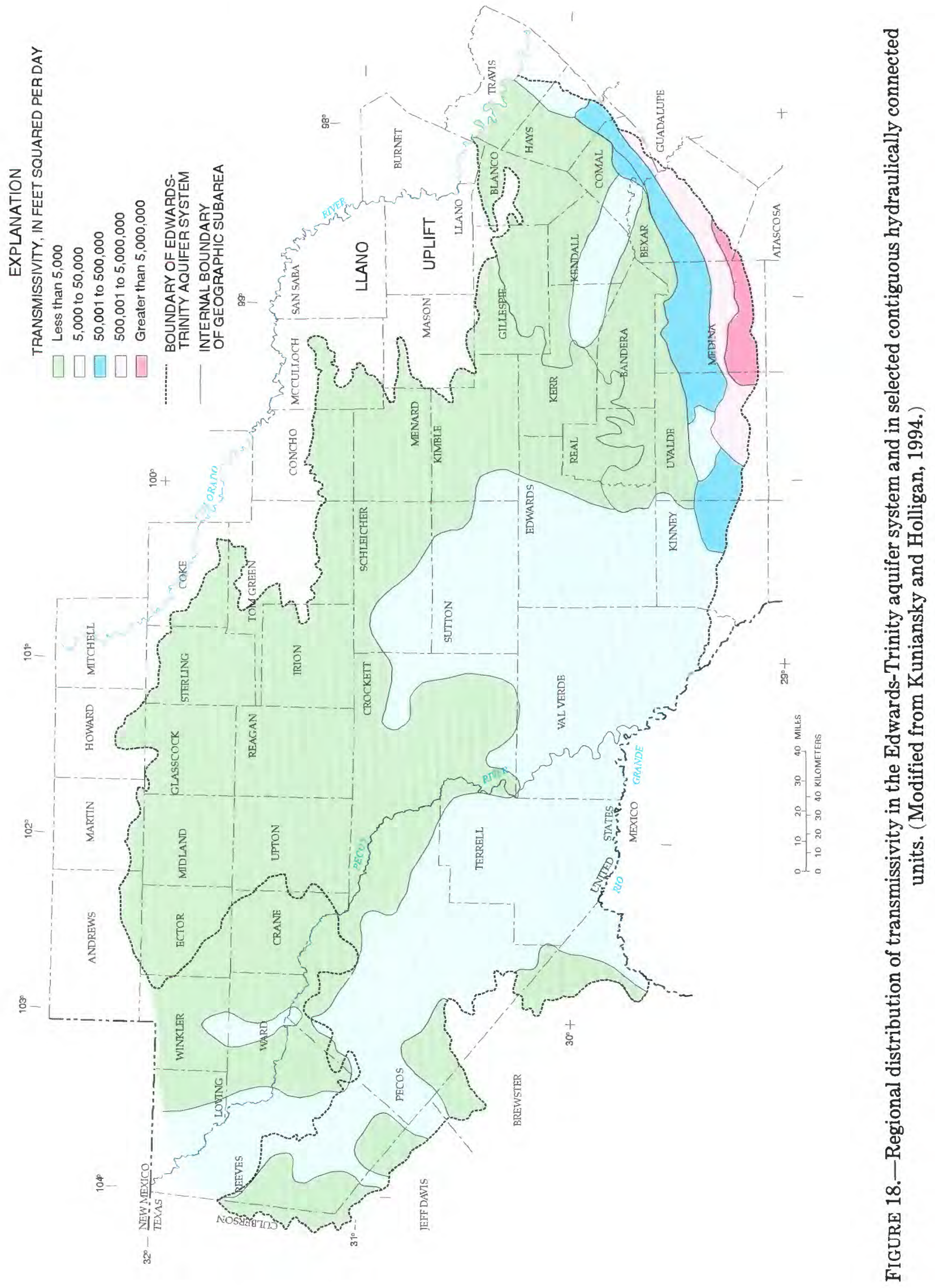


on Theis, 1935) were combined with estimates derived from 269 observations of specific capacity (based on Bedinger and Emmett, 1963). Second, a transmissivity map was constructed for the Hill Country, Edwards Plateau, and Trans-Pecos from the individual estimates of transmissivity. Third, this transmissivity map was combined with a published map of transmissivity for the Edwards aquifer in the San Antonio area of the Balcones fault zone (Maclay and Land, 1988, fig. 19). Fourth, the preliminary map of transmissivity for the entire aquifer system was refined during the calibration of a computer model of ground-water flow. The preliminary transmissivity data were adjusted through the trial-and-error process of minimizing the differences between simulated and observed hydraulic conditions in the aquifer system (Kuniansky and Holligan, 1994).

The final distribution of transmissivity generally reflects larger values for the Hill Country, Edwards Plateau, and Trans-Pecos than those initially obtained from the aquifer-test and specific-capacity data. The initial values were based on data from wells that typically do not penetrate the aquifer system fully; however, the model-calibrated values necessarily incorporate the effects of the total saturated thickness (fig. 17).

Transmissivity in the Edwards-Trinity aquifer system ranges from less than 5,000 to more than $5,000,000 \mathrm{ft}^{2} / \mathrm{d}$. Transmissivity in the Edwards aquifer in the Balcones fault zone ranges from about 10,000 to more than $5,000,000 \mathrm{ft}^{2} / \mathrm{d}$ (Maclay and Land, 1988, p. A26) and probably averages about $750,000 \mathrm{ft}^{2} / \mathrm{d}$ (Maclay and Small, 1986, fig. 20). Transmissivity in the Trinity and Edwards-Trinity aquifers ranges from less than 1,000 to about $50,000 \mathrm{ft}^{2} / \mathrm{d}$ and probably averages less than $10,000 \mathrm{ft}^{2} / \mathrm{d}$ (Walker, 1979; Rees and Buckner, 1980; Ashworth, 1983).

The Balcones faulting triggered the processes responsible for the sizable contrasts between the hydraulic characteristics of the Edwards aquifer and those of the Trinity and Edwards-Trinity aquifers. Although the neomorphic alteration of some strata in the Balcones fault zone has caused a net overall decrease in total porosity, the effects of dissolution overwhelmingly have enhanced the porosity and hydraulic conductivity of the Edwards aquifer (Maclay and Small, 1986, p. 28, 32). The difference between the transmissivity of the Edwards aquifer and that of the deeper Trinity aquifer in the Balcones fault zone is attributable to the effects of fractures that close with depth and a history of comparatively dynamic ground-water flow near the surface. The faulting increased hydraulic gradients across the vertically displaced terrain, which enhanced the percolation of meteoric water from land surface and increased the velocity of shallow ground-water flow. A dynamic regime of shallow ground-water flow evolved that promoted dissolution and enhanced the transmissivity of the Edwards aquifer. Cementation, recrystallization, and replacement resulting from deep burial and comparatively sluggish ground-water movement combined to diminish the transmissivity of the underlying Trinity aquifer, as well as the transmissivity of aquifers outside the fault zone.

The transmissivity of the Trinity aquifer in the Hill Country and of the Edwards-Trinity aquifer in the Edwards Plateau and Trans-Pecos also is small compared with the transmissivity of the Edwards aquifer in the Balcones fault zone. Secondary calcite has occluded most of the primary porosity in carbonate rocks outside the fault zone (Jacka, 1977, p. 191-195) where cavernous porosity (Kastning, 1983; 1986) associated with largescale faulting and aggressive dissolution is comparatively localized, or above the present-day saturated zone. Variations in transmissivity outside the fault zone probably result more from differences in saturated thickness (Ardis and Barker, 1993) than from differences in tectonic and diagenetic activity.

Outside the Balcones fault zone, transmissivity generally is largest (greater than $5,000 \mathrm{ft}^{2} / \mathrm{d}$ ) in areas where the saturated thickness exceeds $500 \mathrm{ft}$; transmissivity generally is smallest (less than $5,000 \mathrm{ft}^{2} / \mathrm{d}$ ) in the northern part of the study area, where the saturated thickness generally is less than $500 \mathrm{ft}$. The regional distributions of transmissivity (fig. 18) and saturated thickness (fig. 17) indicate that, outside the Balcones fault zone, hydraulic conductivity probably averages about $10 \mathrm{ft} / \mathrm{d}$. Within the Balcones fault zone, where the saturated thickness everywhere is greater than $500 \mathrm{ft}$, hydraulic conductivity probably averages between 100 and $1,000 \mathrm{ft} / \mathrm{d}$.

\section{AQUIFERS}

The characteristics of each of the three regional aquifers are summarized below. The summary begins with the Edwards aquifer, the easternmost and most permeable aquifer in the aquifer system.

\section{EDWARDS AQUIFER}

The Edwards aquifer in the Balcones fault zone (Texas Water Development Board, 1990, fig. 1-1) is one of the most productive subsurface reservoirs of potable water in the world. The aquifer lies within the lower part of Washita strata and occupies all Fredericksburg strata in the fault zone. The U.S. Environmental Protection Agency recognizes the Edwards aquifer as a solesource aquifer in the San Antonio area (van der Leeden and others, 1990, p. 713-715), where it serves the domestic, public-supply, industrial, and agricultural 
needs of more than 1 million people. The economies of Medina and Uvalde Counties, west of San Antonio, primarily are based on farming and ranching activities, much of which depends on water pumped from the Edwards aquifer. Northeast of San Antonio, the Edwards aquifer discharges through Comal and San Marcos Springs (fig. 3), whose flows are important to the success of recreational economies, the survival of several threatened or endangered plant and animal species, and the maintenance of downstream fish and wildlife habitats and water supplies. Droughts and the resulting less-than-normal recharge rates and (or) greater-than-normal withdrawal rates periodically cause water-level declines and springflow reductions. The demands for water are expected to continue increasing throughout the central Texas area to sustain agricultural, industrial, and municipal activities and to ensure the survival of threatened and endangered species. Water managers and planners as well as the affected citizens understandably are concerned about the future of the Edwards aquifer and the unique ground-water resource it represents.

Ground-water conditions in the Edwards aquifer have evolved from tectonic and diagenetic events superimposed upon depositional products of the San Marcos arch (Rose, 1972), Devils River trend (Lozo and Smith, 1964), and Maverick basin (Winter, 1962). The part of the Edwards aquifer that formed on the San Marcos arch and in the Devils River trend extends from the Colorado River through eastern Uvalde County (fig. 2). The part of the Edwards aquifer that formed in the Maverick basin extends from central Uvalde County through central Kinney County. This section of the report discusses ground-water conditions in the Edwards aquifer east of central Uvalde County in rocks (fig. 11) that formed on the San Marcos arch (the Georgetown, Person, and Kainer Formations) and in the Devils River trend (the Devils River Formation). Ground-water conditions in equivalent rocks that formed in the Maverick basin (the Salmon Peak, McKnight, and West Nueces Formations) are discussed under "Edwards Plateau," because the hydraulic conditions in western Uvalde and eastern Kinney Counties (at the westernmost end of the Balcones fault zone) are most like those in the Edwards-Trinity aquifer in the southern part of the Edwards Plateau.

The Edwards aquifer is hydraulically unconfined in the outcrop area of the Edwards Group (Rose, 1972, pl. 2) and in the outcrop areas of the Devils River, Salmon Peak, McKnight, and West Nueces Formations across parts of Kinney, Medina, and Uvalde Counties (fig. 2). The Edwards aquifer is confined in the downdip area beneath the Navarro-Del Rio confining unit. The confined part of the aquifer is bound on its down- dip (gulfward) margin by a freshwater/saline-water transition zone of brackish water. The concentrations of dissolved solids downdip of the transition zone exceed $1,000 \mathrm{mg} / \mathrm{L}$ (Maclay and others, 1980, p. 13) and rapidly increase in a gulfward direction to more than 250,000 $\mathrm{mg} / \mathrm{L}$ (Maclay and Land, 1988, p. A12) near the Stuart City reef trend (fig. 6). The concentration of dissolved solids in the Edwards aquifer updip of the transition zone ranges from about 250 to $300 \mathrm{mg} / \mathrm{L}$ (Pavlicek and others, 1987, p. 3).

Diagenetic differences between rocks of the salinewater zone and those of the Edwards aquifer were attributed by Ellis (1986, p. 101) to the effects of vastly different pore-water chemistries since the Miocene Epoch, when the majority of the normal (down-to-thesoutheast) faulting in the Balcones fault zone is believed to have taken place. Although the saline-water zone is saturated with respect to calcite, dolomite, gypsum, celestite, strontianite, and fluorite, water in the Edwards aquifer is saturated only with respect to calcite (Pearson and Rettman, 1976, p. 19). The rocks of the highly permeable Edwards aquifer mostly are calcitic, dedolomitized, and neomorphically altered to coarse microspar and pseudospar. The comparatively impermeable rocks of the saline-water zone mostly are dolomitic and contain unoxidized organic material, including petroleum, and accessory minerals such as pyrite, gypsum, and celestite (Maclay and Small, 1986, p. 28). The negligible hydraulic conductivity of these rocks is sustained by a scarcity of permeabilityenhancing features (such as open fractures) to interconnect the generally minor interparticle and intercrystalline porosity that is characteristic of the saline-water zone (Kozik and Richter, 1979, p. 26).

As a result of the Balcones faulting and associated fracturing, large volumes of freshwater began to infiltrate strata within the fault zone that previously had been isolated from meteoric conditions. The Edwards aquifer subsequently resulted from joint cavities and solution channels (some cavernous in extent) that evolved as fractures and bedding planes widened through dissolution (Abbott, 1975). Additionally, the preferential dissolution of evaporites and other soluble minerals, fossil parts, and burrow filling has rendered a honeycombed or vuggy porosity to much of the aquifer (Hovorka and others, 1995).

Ground-water flow in the Edwards aquifer largely is controlled by an anisotropic pattern of hydraulic conductivity. The anisotropy originates from the effects of barrier faults, which displaced the strata vertically so that permeable rock is juxtaposed opposite impermeable strata (pl. 3), thus blocking or impeding groundwater flow in directions normal to the faults. The increases in hydraulic conductivity that resulted from 
post-fault dissolution were greatest along joint cavities and solution channels aligned with the fault zone. The resultant vectors of transmissivity therefore trend approximately N. $40^{\circ}$ to $70^{\circ} \mathrm{E}$. (Collins, 1995). Because the faults are most abundant across northern Medina, central Bexar, southern Comal, southern Hays, and central Travis Counties (Baker and others, 1986, fig. 2; Maclay and Small, 1986, fig. 3), the strongest anisotropy exists east of Uvalde County. The anisotropy is so dominant in the subcrop of the Edwards aquifer in Bexar County (Arnow, 1963, p. 29-31) that most ground-water flow appears to nearly parallel the equipotential lines on regional potentiometric maps of the San Antonio area (Maclay and Small, 1986, fig. 23).

From upgradient parts of the outcropping recharge area, ground water generally flows downdip in a southerly direction. The barrier faults typically block the southeastward flow of ground water and divert it northeastward, along flowpaths aligned with the fault zone (Arnow, 1963, p. 29-31). In some places, a secondary network of transverse faults obstructs the major northeast-trending flowpaths, imposing internal boundaries that further divert or compartmentalize the flow system (Maclay and Small, 1983, p. 135-145). As a result, local patterns of ground-water flow can be extremely complex, making predictions about future responses to prolonged drought or additional pumping difficult to determine (G.E. Groschen, U.S. Geological Survey, written commun., 1994).

The Edwards aquifer primarily is recharged by the (1) seepage from streams draining the Hill Country, where the streams flow onto permeable outcrop areas of the Edwards Group and Devils River Formation (Puente, 1978); (2) infiltration of precipitation in the outcrop areas; (3) subsurface inflow across the updip margin of the Balcones fault zone where the Trinity aquifer is laterally adjacent to downfaulted Edwards strata (Veni, 1994); and (4) diffuse upward leakage from the underlying Trinity aquifer. Recharge rates vary considerably with time, depending upon antecedent conditions and the frequency and intensity of precipitation. Although the actual rates of recharge cannot be measured, estimates of recharge routinely are made for water-management purposes.

The estimates of recharge to the Edwards aquifer from sources (1) and (2) above range from about 44,000 acre-ft during 1956 to about 2,500,000 acre-ft during 1992, and total recharge from these sources has averaged about 680,000 acre-ft/yr since the mid-1930's (Bader and others, 1993, table 4.1). The amount of water entering laterally from the Hill Country is unknown; however, a preliminary estimate (assuming an average hydraulic gradient of $20 \mathrm{ft} / \mathrm{mi}$ and an average transmissivity of $5,000 \mathrm{ft}^{2} / \mathrm{d}$ ) indicates that this inflow probably exceeds $100,000 \mathrm{acre}-\mathrm{ft} / \mathrm{yr}$. The rates of diffuse upward leakage also are unknown; however, the preliminary results of computer simulation (Kuniansky and Holligan, 1994) indicate a long-term average rate of about 10,000 acre-ft/yr.

Most ground-water discharge takes place as (1) springflow, (2) withdrawals by industrial-, irrigation-, and public-supply wells, (3) diffuse upward leakage to Upper Cretaceous strata, and (4) leakage to the Colorado River. Springflow has averaged about 400,000 acre-ft/yr since the mid-1930's (Slade and others, 1986, p. 69; Bader and others, 1993, table 5.1). After steadily increasing from about 100,000 acre-ft/yr during the 1930 's to an average 470,000 acre- $\mathrm{ft} / \mathrm{yr}$ during the $1980^{\prime}$ 's, ground-water withdrawals recently have tapered to an average 420,000 acre-ft/yr during 1990-93 (Bader and others, 1993; Bill Couch, Barton SpringsEdwards Aquifer Conservation District, oral commun., 1993). The rates of leakage from the aquifer to the Upper Cretaceous strata and to the Colorado River are unknown; however, they undoubtedly are considerably smaller than the rates of springflow and pumpage.

Most of the ground water for public-supply use is withdrawn near San Antonio, where water levels in a key U.S. Geological Survey observation well (AY-68$37-203$, fig. 16) have varied between a low of $612.5 \mathrm{ft}$ above sea level in 1956 to a high of $703.3 \mathrm{ft}$ above sea level in 1992 (Bader and others, 1993, table 2.1). Although droughts and floods have caused substantial short-term fluctuations in ground-water levels, longterm hydrographs indicate no net decline (or rise) of water levels in the San Antonio area over the last 80 years (R.W. Maclay, U.S. Geological Survey, written commun., 1990).

\section{TRINITY AQUIFER}

The Trinity aquifer (Texas Water Development Board, 1990, fig. 1-1), which consists entirely of Trinity strata, dominates the ground-water hydrology of the Hill Country $\left(5,300 \mathrm{mi}^{2}\right)$. As a result of the Balcones faulting and subsequent erosion, most Fredericksburg strata and practically all Washita strata have been removed from the Hill Country. However, a few domestic- and stocksupply wells in interstream areas of northwestern Bandera, northern Kendall, and eastern Kerr Counties are completed in the Fort Terrett Formation. Likewise, the Devils River Formation could contribute to the water supply in small parts of southern Real and northern Uvalde Counties.

The Trinity aquifer includes three relatively permeable zones that are separated vertically by two relatively impermeable intervals. The upper Trinity permeable zone comprises the upper member of the Glen 
Rose Limestone. The middle Trinity permeable zone comprises the lower member of the Glen Rose Limestone, the Hensel Sand, and the Cow Creek Limestone. The lower Trinity permeable zone comprises the Sycamore Sand, updip, and the Sligo and Hosston Formations, downdip.

The upper Trinity permeable zone is separated from the middle Trinity permeable zone by thin, hydraulically tight interbeds within the upper part of the Glen Rose Limestone. According to Ashworth (1983, p. 33), these interbeds are "*** laterally continuous, alternating resistant and nonresistant beds of blue shale, nodular marl, and impure fossiliferous limestone." Ground water in interstream areas of the Hill Country commonly is perched atop these interbeds, above the base level of the adjacent streams. Because of their relatively high stratigraphic position, the interbeds typically are breached by steep-sided stream channels that are connected hydraulically to the regional potentiometric surface (Kuniansky, 1990).

The middle Trinity permeable zone (fig. 19) generally is separated from the lower Trinity permeable zone (fig. 20) by the Hammett confining unit (fig. 21), which is composed of the Hammett Shale. The hydraulic distinction between the middle and lower permeable zones lessens northward, as the Hammett Shale pinches out against the Llano uplift. However, the Hammett Shale is areally continuous and relatively impermeable throughout most of the Hill Country where typically it is about $50 \mathrm{ft}$ thick. Dislocation of the Pine Island Shale Member (downdip equivalent of the Hammett Shale) by highangle normal faults disrupts the confining effect of the shale in the Balcones fault zone. Thus, the Hammett confining unit is limited to most of the Hill Country and a small southeastern part of the Edwards Plateau (figs. 2, 21; pl. 1).

The hydrology of the Trinity aquifer varies greatly in the Hill Country in response to its depth below land surface and diverse diagenetic history. Whereas unconfined conditions typically prevail within a few hundred feet of land surface, ground water generally is confined in the deeper strata. Although the evolution of stable minerals has diminished the hydraulic conductivity of most downgradient, subcropping strata, the leaching of evaporites and unstable carbonate constituents has enhanced the hydraulic conductivity of some upgradient, outcropping rocks. The Glen Rose Limestone is unusually permeable in outcrop and shallow subcrop areas of northern Bexar and southwestern Comal Counties, where the unit is cavernous (Kastning, 1986; Veni, 1994). Sinkholes in streambeds atop the Glen Rose Limestone frequently intercept surface water to provide substantial amounts of recharge to the Trinity aquifer (Ashworth, 1983, p. 10). The quartzose clastic facies of the updip Hensel Sand include some of the most permeable (albeit, typically unsaturated) sediments in the Hill Country. Because outcrop surfaces of the Cow Creek Limestone characteristically are riddled with moldic porosity from the dissolution of mollusk shells, most of its outcrop area is highly permeable and particularly receptive to recharge.

Vertical differences in hydraulic head are common within the Trinity aquifer. The greatest and most widespread head differences generally occur across downdip parts of the Hammett Shale, an areally extensive confining unit that ranges from about 40 to $80 \mathrm{ft}$ thick over most of the Hill Country (Amsbury, 1974, p. 18). Ashworth (1983, figs. 16-18) reports that differences in hydraulic head across the Hammett confining unit exceed $100 \mathrm{ft}$ over parts of eastern Bandera, Kendall, and eastern Kerr Counties. Differences in head also are caused by strongly cemented, thin interbeds of claystone, marl, and shale that are interspersed throughout the upper and middle parts of the Trinity aquifer, but most commonly within the Glen Rose Limestone. Water levels in the Glen Rose Limestone near the southeastern corner of Edwards County are more than $200 \mathrm{ft}$ higher than those in the underlying Hosston Formation.

The Trinity aquifer is recharged, in order of importance, by the (1) lateral subsurface inflow of ground water from the Edwards Plateau, (2) infiltration of precipitation on the outcrop area, and (3) seepage of surface water from shallow, tributary streams in upland areas. The strongly cemented, hydraulically tight interbeds in the upper and middle parts of the Trinity aquifer impede the downward percolation of precipitation. Meteoric water that infiltrates the interstream areas moves laterally atop the dense interbeds more readily than it percolates vertically through them. Ground water emerges from springs and seeps along the tops of the impermeable bedding where the bedding is breached by the rugged topography of the Hill Country. Thus, instead of percolating to deeper permeable zones, much of the water in shallow parts of the Trinity aquifer discharges to the deeply entrenched, perennial streams that drain the area (Ashworth, 1983, p. 47).

Streamflow gains in the Hill Country subsequently are lost downstream in the Balcones fault zone where the streams cross faults that juxtapose nonleaky streambeds composed of Glen Rose Limestone with permeable streambeds on the outcrop of the Edwards aquifer. Discharge from the Trinity aquifer additionally occurs as lateral subsurface inflow (Veni, 1994) and diffuse upward leakage to the Edwards aquifer and through wells that withdraw water for domestic, industrial, irrigation, public-supply, and stock uses. Ground-water withdrawals from the Trinity aquifer averaged between 


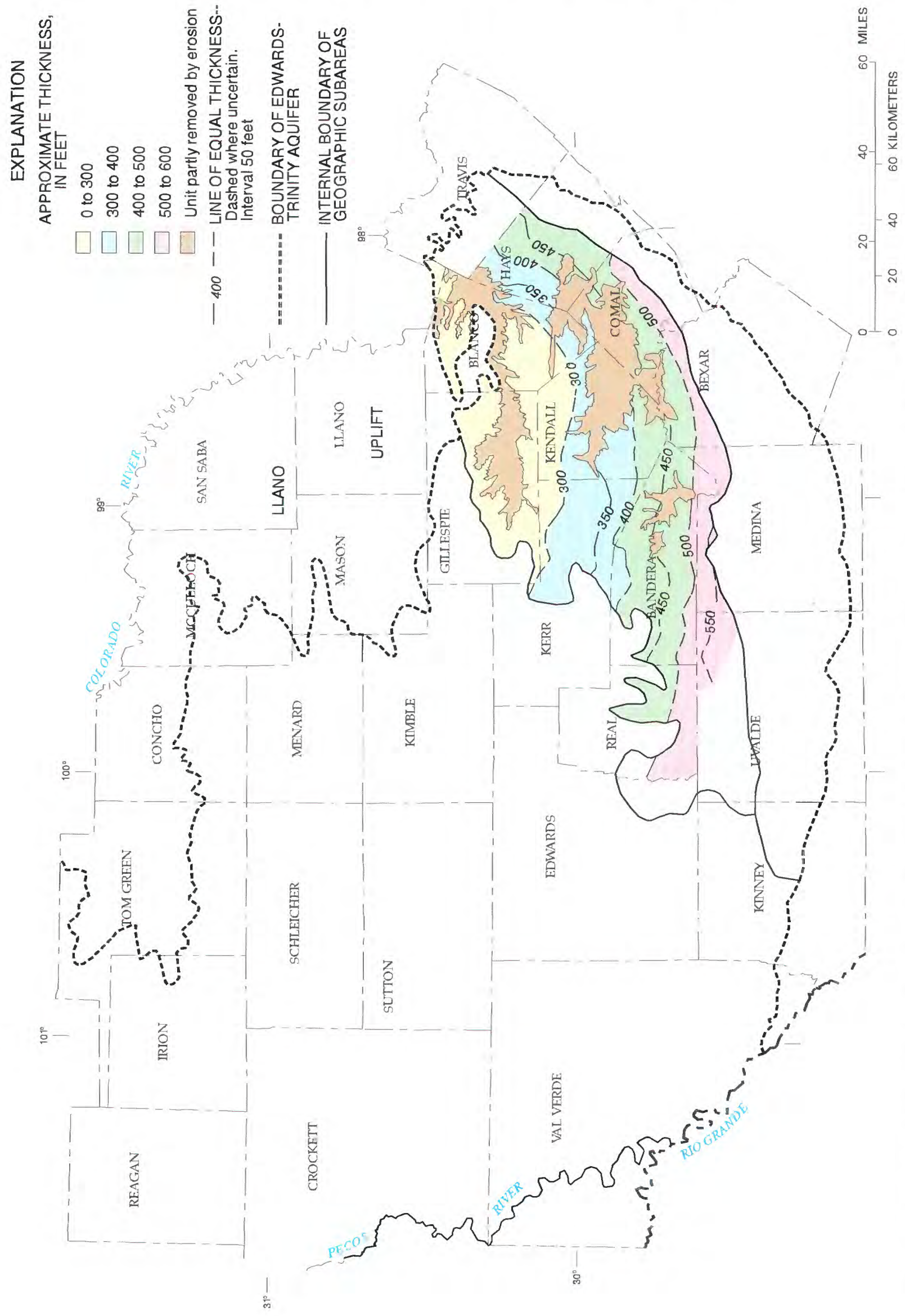



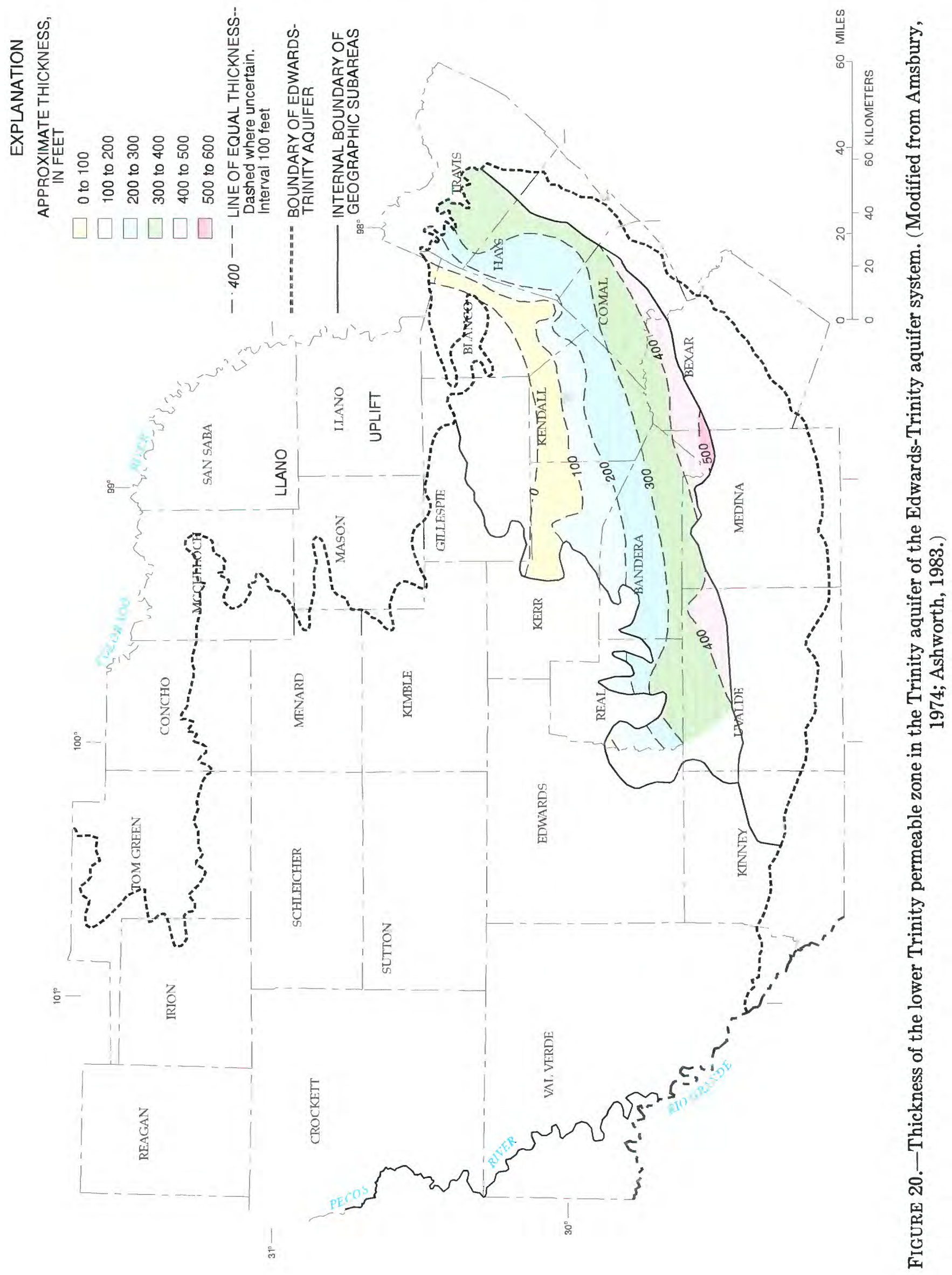

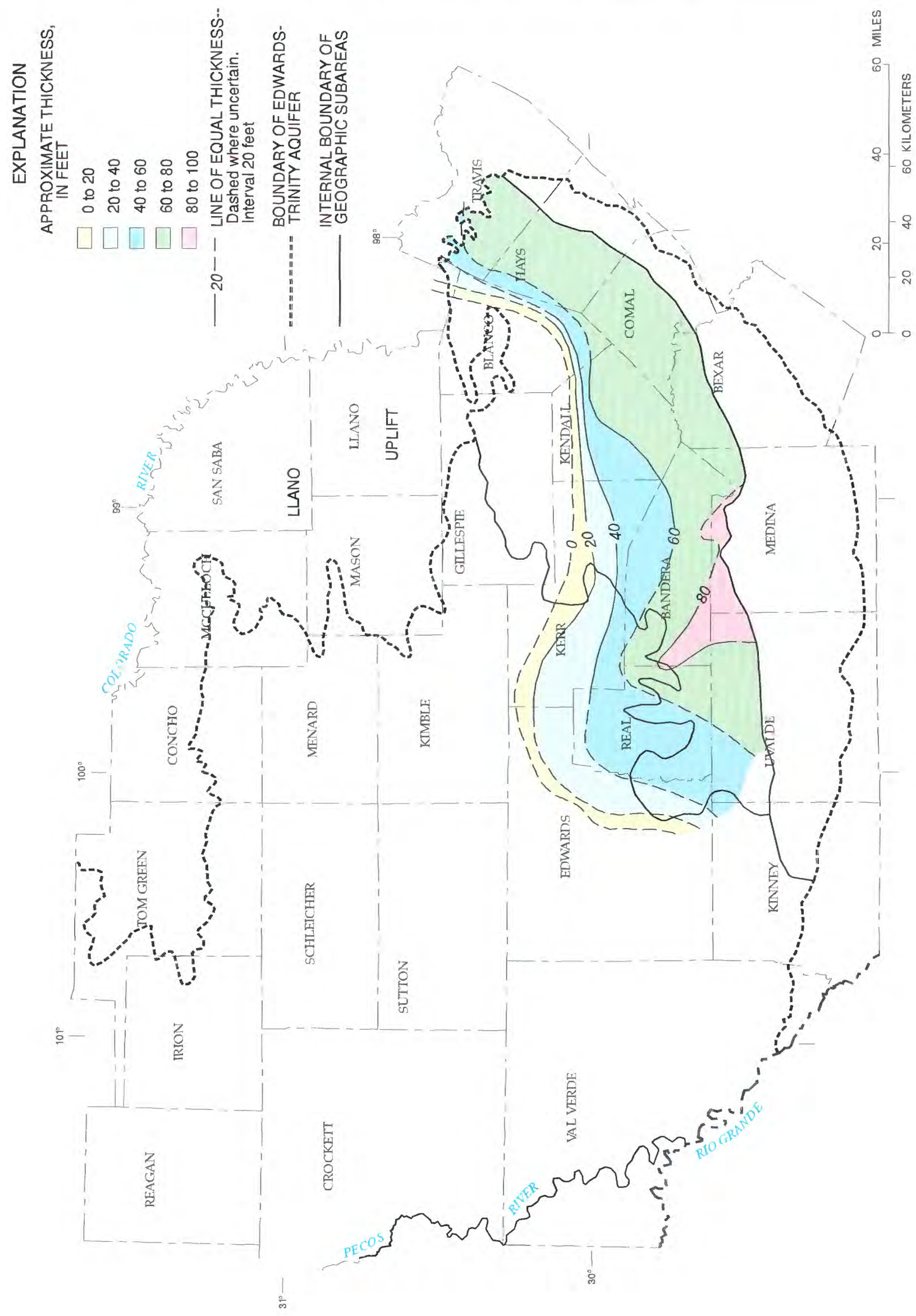
10,000 and 15,000 acre-ft/yr during 1975-76 (Lurry and Pavlicek, 1991) and totaled about 13,500 acre-ft during 1990 (D.L. Lurry, U.S. Geological Survey, written commun., 1994).

Long-term hydrographs of ground-water levels in the Hill Country indicate that water levels can vary greatly over short periods. Water levels typically vary $50 \mathrm{ft}$ or more between winter highs and summer lows. The seasonal variances are greatest in wells that are less than about $100 \mathrm{ft}$ deep. Because the hydraulic conductivity generally is small and most high-demand wells are prone to large drawdowns during extended periods of ground-water withdrawals, the Trinity aquifer in the Hill Country generally is affected by drought more quickly than is the Edwards aquifer in the Balcones fault zone.

The transmissivity of the Trinity aquifer is highly variable because the saturated thickness varies with hydraulic head (fig. 16) and the altitude of the underlying pre-Cretaceous rocks (fig. 7), both of which can change greatly over a short distance in the Hill Country (Barker and Ardis, 1992; Bush and others, 1993). Transmissivity values, as derived from aquifer tests and estimated from specific-capacity data (Ashworth, 1983), range from less than 1,000 to about $50,000 \mathrm{ft}^{2} / \mathrm{d}$. From the results of a regional ground-water-flow model, transmissivity appears to average less than $10,000 \mathrm{ft}^{2} / \mathrm{d}$ (Kuniansky and Holligan, 1994). The transmissivity of the Trinity aquifer in the Balcones fault zone mostly is undetermined; however, sparse data indicate that it is negligible compared to that of the overlying Edwards aquifer, and that it is no larger than that of the Trinity aquifer in the Hill Country.

\section{EDWARDS-TRINITY AQUIFER}

The Edwards-Trinity aquifer (Texas Water Development Board, 1990, fig. 1-1) extends over about 24,000 $\mathrm{mi}^{2}$ of the Edwards Plateau and about $9,700 \mathrm{mi}^{2}$ of the Trans-Pecos. None of the rock units that compose this widespread aquifer is uniformly permeable. However, the rocks are combined regionally into one aquifer because no single rock unit stands out as substantially more or less permeable than the rest.

\section{Edwards Plateau}

The Edwards-Trinity aquifer in the Edwards Plateau includes all of the Fredericksburg and Trinity strata, plus all Washita rocks below the Del Rio Clay or the Buda Limestone (where the Del Rio Clay is absent). The Washita and Fredericksburg strata are the most important water-producing rocks over more than two-thirds of the Edwards Plateau. Except where the Washita and Fredericksburg strata are absent or thinly saturated, the hydrologic characteristics of the Trinity strata largely are untested. Water wells generally do not penetrate below the base of Fredericksburg strata (fig. 22) unless the Washita and Fredericksburg strata have failed to provide sufficient amounts of potable water. The Fredericksburg rocks generally are the most reliable sources of potable water in the area because the Trinity strata taper to zero or negligible thickness against the Llano uplift (fig. 8) and the regional ground-water-flow system is below the base of Washita rocks in most northern parts of the Edwards Plateau.

The Washita and Fredericksburg rocks are the principal water-producing zones south of northern Concho, Irion, Reagan, Tom Green, and Upton Counties (fig. 2), except where they are breached along the valleys of the Concho, Guadalupe, Llano, Pecos, Pedernales, and San Saba Rivers (fig. 3). In these topographically low areas, the Glen Rose Limestone, Hensel Sand, and basal Cretaceous sand supplement the stream-valley alluvium as major sources of ground water. Although the Washita rocks are used only minimally for water supply in the northern Edwards Plateau, they become more important sources of ground water as they thicken and become increasingly saturated toward the south. Where the Fort Lancaster Formation (west) and Segovia Formation (east) occupy the highest elevations in the Edwards Plateau, they generally are unsaturated, thinly saturated, or contain only perched ground water. However, the Fort Lancaster and Segovia Formations, in addition to the Devils River and Salmon Peak Formations (in the Devils River trend and Maverick basin, respectively), are important water-producing units in parts of Edwards, Kinney, and Val Verde Counties.

The Salmon Peak Formation is "moderately to very permeable" near the top (Maclay and Small, 1986, table 1). The lower part of the Salmon Peak Formation is nearly impermeable, except where fractured. The McKnight Formation locally contains permeable pockets of leached evaporites, but mostly it is considered nearly impermeable. Although the upper part of the West Nueces Formation is "moderately permeable," the lower part is nearly impervious to ground water (Maclay and Small, 1986, table 1).

The Devils River Formation is "very permeable and porous," especially in middle and upper parts of the unit that contain collapse breccia or vuggy zones of leached rudists (Maclay and Small, 1986). The upper and middle parts of the formation compose the principal water-producing zone in southern Edwards County and in central Val Verde County. The Devils River Formation supplies large amounts of irrigation water in western parts of the Balcones fault zone (in Medina and Uvalde Counties), where this unit is considered a major aquifer (Maclay and Small, 1986, table 1). 


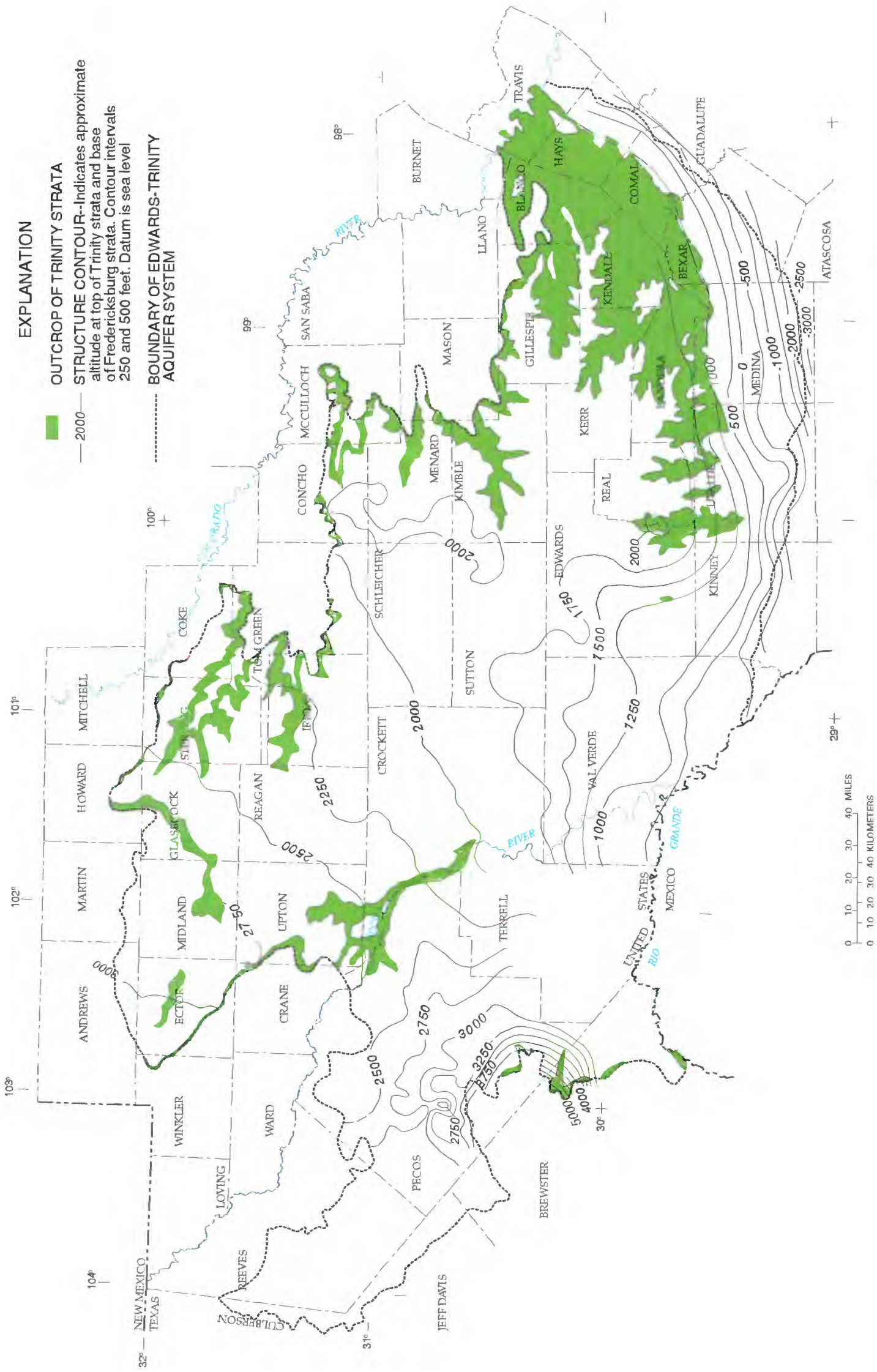

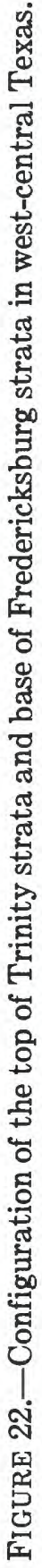


The Fort Terrett Formation provides most of the ground water used on the Edwards Plateau. The "burrowed zone" (pl. 1), near the base of this formation, might be the most permeable part of the Edwards Group outside the intensively fractured Balcones fault zone. The permeable nature of the burrowed zone results from the preferential leaching of burrow fillings, leaving a honeycombed pattern of porosity in the remaining rock (Rose, 1972, p. 34). The overlying "Kirschberg evaporite zone" (pl. 1) also is highly permeable where it is brecciated as a result of postdepositional leaching and structural collapse. Although the zones of Kirschberg breccia west of the Balcones fault zone mostly are unsaturated, the breccia enhances recharge in eastern parts of the Edwards Plateau by permitting comparatively large amounts of precipitation to infiltrate the subsurface.

With the exception of a few areas with shallow alluvial aquifers, the basal Cretaceous sand of Trinitian age is the most important water-producing unit in Ector, Glasscock, Midland, Sterling, and Upton Counties and along the Pecos River valley in Crockett County (fig. 8). The basal Cretaceous sand might supply nearly as much ground water as that pumped from Fredericksburg rocks in southern Irion, southeastern Reagan, and southern Tom Green Counties. Few water wells are deep enough to penetrate the basal Cretaceous sand over most of Crockett, Edwards, Schleicher, Sutton, and Val Verde Counties.

The Trinity units most likely to contain potable ground water in southern parts of the Edwards Plateau (northwestern Bandera, eastern Edwards, western Kerr, and northern Real Counties) are the lower member of the Glen Rose Limestone, the Hensel Sand, and the Cow Creek Limestone. The hydraulic characteristics of the much deeper Pearsall (undivided), Sligo, and Hosston Formations mostly are unknown. However, these lower Trinity units generally are more than $750 \mathrm{ft}$ below land surface in this area. Because freshwater recharge to such depths is minimal in southern parts of the Edwards Plateau, water in the Pearsall, Sligo, and Hosston Formations probably contains dissolved constituents in concentrations (Walker, 1979, p. 93-95) that exceed the local standards for drinking water (Texas Department of Health, 1977).

The Hammett Shale, which is continuous and hydraulically tight over most of the Hill Country (fig. 3), grades northwestward across Edwards County into the comparatively permeable basal Cretaceous sand (figs. 8, 9, $J-J^{\prime}$ ). Accordingly, the effectiveness of the Hammett confining unit diminishes west of the Hill Country, as the shale grades into sand. The Trinity strata are connected hydraulically to the overlying
Fredericksburg strata, therefore, over most of the Edwards Plateau.

Water-producing zones in the Edwards Plateau mostly are confined or semi-confined, except in the shallowest zones and near the outer margins of Fredericksburg strata where the underlying Trinity sediments crop out. No confining unit is extensive enough to be mapped west and north of the western and northern limits of the Hammett confining unit (fig. 2). However, the effects of many discontinuous low-permeability beds accumulate with increasing depth below land surface to confine some deeper parts of the Edwards-Trinity aquifer. Unconfined conditions dominate where gaining streams are incised into sandy Trinity sediments along the Concho, Guadalupe, Llano, Pecos, Pedernales, and San Saba Rivers (fig. 3). From generally unconfined or semi-confined conditions in the west, the Edwards-Trinity aquifer becomes progressively more confined toward the southeast in response to an increasing thickness of overlying lowpermeability beds, in that direction. Observations of diurnal changes in barometric pressure, water levels that rise above the top of water-producing zones, and entrapped hydrogen sulfide gas prompted Walker (1979, p. 49) to suggest that "*** water-table conditions may not be as prevalent as previously reported." Previous reports of unconfined conditions were based on observations from older, relatively shallow wells in the Edwards Plateau.

The Edwards-Trinity aquifer merges hydraulically with locally permeable Paleozoic strata around the western and southern flanks of the Llano uplift in Gillespie, Mason, and McCulloch Counties (fig. 2). In this area, deeply eroded Paleozoic and Precambrian rocks (fig. 7) form a subtle topographic basin (fig. 5), where a shallow ground-water regime has developed along fractures and joint cavities. Water from the northeastern fringe of the Edwards-Trinity aquifer merges with the shallow flow regime of the Marble Falls, Ellenburger-San Saba, and Hickory aquifers (Barker and Ardis, 1992) before discharging into the Colorado River and northeastward-flowing tributaries that drain the Llano area (figs. 2,3).

The Edwards-Trinity aquifer overlies the Dockum Group of Triassic age in large parts of Crockett, Ector, Irion, Reagan, and Sterling Counties. Where middle parts of the Dockum Group are composed of sandy sediments that contain freshwater (Barker and Ardis, 1992), they comprise the Dockum aquifer (Texas Water Development Board, 1990, p. 1-6). Where upper, less permeable parts of the Dockum Group are absent, the Dockum aquifer merges in places with the basal Cretaceous sand of the Edwards-Trinity aquifer (fig. 2, pl. 4). In such places, the depth of ground-water circulation 
might increase a few hundred feet to the lower part of the Dockum Group-or to the top of Permian red beds, where the lower Dockum unit is absent. Water from the Dockum aquifer varies considerably in quantity and quality. However, well yields characteristically are less than a few hundred gallons per minute, and the water typically contains sodium, sulfate, chloride, and fluoride in concentrations (Ashworth and Christian, 1989) that exceed the local standards for drinking water (Texas Department of Health, 1977).

The Edwards-Trinity aquifer pinches out below the Ogallala Formation of Tertiary age along the northwestern edge of the Edwards Plateau (pl. 3) in Andrews, Glasscock, Howard, and Martin Counties (fig. 2). Coarse sand and gravel of the Ogallala Formation, which forms the High Plains aquifer (Gutentag and others, 1984, p. 8-13) in northwest Texas, fill erosional channels atop the basal Cretaceous sand in the northwestern part of the study area. Water discharging in a southeasterly direction from the southern tip of the High Plains aquifer recharges the northwestern fringe of the Edwards-Trinity aquifer.

From the northwestern part of the Edwards Plateau, water in the Edwards-Trinity aquifer generally flows southeastward along hydraulic gradients that average about $10 \mathrm{ft} / \mathrm{mi}$. Local exceptions to the regional groundwater-flow pattern result from topographic and drainage variations and depressions in the potentiometric surface caused by pumping wells. The maximum hydraulic head in the Edwards-Trinity aquifer is in northwestern Ector County at about $3,100 \mathrm{ft}$ above sea level, and the minimum hydraulic head, in southern Val Verde County, is about 2,000 ft above sea level (Bush and others, 1993). In the southwestern part of the Edwards Plateau, ground water discharges to the Pecos River and Rio Grande. In the northeast, ground water discharges to the Colorado River and its tributaries. In the southeast, ground water discharges to headwater reaches of the Frio, Guadalupe, Medina, and Nueces Rivers (fig. 3) and as lateral subsurface inflow to the Hill Country.

Most recharge to the Edwards-Trinity aquifer results from the infiltration of precipitation from land surface and from seepage losses through streambeds of intermittent streams. Discharge from the aquifer mainly occurs through (1) springs in the stream-dissected northeastern and southeastern fringes of the Edwards Plateau; (2) base flow to gaining reaches of the Concho, Llano, and Pecos Rivers; and (3) wells pumped for domestic, irrigation, and stock water. Recharge and discharge each average less than 1 in/yr over the Plateau, increasing from less than $0.5 \mathrm{in} / \mathrm{yr}$ in the western part to more than $0.5 \mathrm{in} / \mathrm{yr}$ in the extreme eastern part of the area (E.L. Kuniansky, U.S. Geological Survey, written commun., 1990).

Lurry and Pavlicek (1991) reported that during 197576 about 80 percent $(100,000$ acre- $\mathrm{ft})$ of the average annual pumpage from the Edwards-Trinity aquifer in the Edwards Plateau (nearly 130,000 acre-ft/yr) was used for irrigation, stock, and rural domestic activities. Walker (1979, p. 76) estimated that about 72 percent of the total pumpage during 1972 was for irrigation. Irrigation pumpage from Glasscock and Midland Counties alone accounted for more than one-third of all pumpage during the mid-1970's (Lurry and Pavlicek, 1991). Since the mid-1970's, annual withdrawals from the EdwardsTrinity aquifer have fluctuated between about 85,000 acre-ft (during 1985) and about 128,000 acre-ft (1990) (D.L. Lurry, U.S. Geological Survey, written commun., 1992).

Ground-water levels in the Edwards Plateau mostly vary in response to short-term fluctuations in recharge and long-term variations in discharge. Most of the fluctuation in recharge results from cyclic patterns in precipitation, and most of the variation in discharge results from pumpage trends. Water levels have declined where and when the rates of recharge and natural discharge (evapotranspiration, springflow, and base flow) have not compensated for increasing rates of groundwater withdrawal.

During the last 50 years, water levels have declined more than $50 \mathrm{ft}$ in northwestern parts of the Edwards Plateau, including parts of Ector, Glasscock, Midland, Reagan, Sterling, and Schleicher Counties (Walker, 1979, p. 96-100). Data from an observation well in Reagan County indicate more than $100 \mathrm{ft}$ of decline since 1950 (Bush and others, 1993). The nearly continuous, longterm nature of water-level decline in many wells reflects a direct relation to a rapid increase in the number of irrigation wells that began about 1946 and continued through the 1960's.

Since the late 1970 's, water levels in most parts of the Edwards Plateau have stabilized or begun to recover, reflecting the results of recent efforts to reduce the need for irrigation and to conserve water (J.B. Ashworth, Texas Department of Water Resources, written commun., 1991). Water-level hydrographs for central parts of the Edwards Plateau reflect a cyclic relation between recharge and precipitation: (1) declining water levels during most of the 1960's, when precipitation was below normal; (2) rising water levels during most of the 1970's, when precipitation was above normal; and (3) declining water levels during most of the 1980's, when precipitation was below normal. Many of the highest recorded water levels during the past 30 years in Crockett, Edwards, Kimble, Schleicher, and Sutton Counties occurred during the middle-to-late 1970's. 
Transmissivity is relatively small in the Edwards Plateau, where it averages about 100 to 1,000 times less than that in the Balcones fault zone. Estimates of transmissivity from aquifer-test and specific-capacity data indicate that it probably is less than $5,000 \mathrm{ft}^{2} / \mathrm{d}$ over most of the Edwards Plateau (Walker, 1979, p. 72-75). Exceptions are in the southern part of the Edwards Plateau where Trinity rocks thicken southward into the Rio Grande Embayment (fig. 6) and wells completed in the relatively permeable Devils River Formation yield up to $500 \mathrm{gal} / \mathrm{min}$. Results of a ground-water-flow model indicate that transmissivity probably averages about $10,000 \mathrm{ft}^{2} / \mathrm{d}$ over parts of Edwards, Terrell, and Val Verde Counties where the Cretaceous sediments are thickest (Kuniansky and Holligan, 1994).

\section{Trans-Pecos}

The Edwards-Trinity aquifer in the Trans-Pecos (fig. 3) includes all the Fredericksburg and Trinity strata plus all Washita rocks below the Del Rio Clay or the Buda Limestone (where the Del Rio Clay is absent). The hydrogeologic framework of Pecos, Reeves, and Terrell Counties is complicated structurally. The structural complexity results from the collapse of salt-laden Permian rocks that underlie much of the area and crustal deformation south and west of the area during Cenozoic time (Henry and Price, 1985). Less is understood about the Edwards-Trinity aquifer in the TransPecos than perhaps any other part of the EdwardsTrinity aquifer system.

The Edwards-Trinity aquifer does not dominate the ground-water-flow system in the Trans-Pecos as it does in the Edwards Plateau. On average, the EdwardsTrinity aquifer is less permeable than the contiguous, hydraulically connected Cenozoic Pecos alluvium aquifer (fig. 2). The average hydraulic conductivity of the Edwards-Trinity aquifer probably is no greater than that of the most permeable part of the underlying Dockum aquifer. Therefore, the combined influence of all of the interconnected permeable rocks should be considered when conceptualizing the regional flow system in the Trans-Pecos.

The hydraulic conditions of the Washita and Fredericksburg rocks in the Trans-Pecos largely are unpredictable because the available hydrogeologic data are sparse and inconclusive. Most of the Washita strata and much of the Fredericksburg strata in Pecos and Terrell Counties are unreliable sources of ground water because they are relatively impermeable or lie above the regional ground-water-flow system. The hydraulic characteristics of the Washita and Fredericksburg strata in Reeves County have not been differentiated from those of the underlying Trinity rocks (Ogilbee and others, 1962). Where the Washita and Fredericksburg strata are saturated in eastern Pecos and Terrell Counties, they provide small amounts of water to stocksupply wells. Southwest of Fort Stockton in westcentral Pecos County, limestone of the Finlay Formation contains a fault-controlled network of interconnected solution channels that has yielded up to $2,500 \mathrm{gal} / \mathrm{min}$ to irrigation-supply wells (Armstrong and McMillion, 1961 , p. 59). In areas where solution channels have not developed, the equivalent strata yield considerably less water (100 to $500 \mathrm{gal} / \mathrm{min}$ ) to individual wells. The discharge from many wells and most springs in southwestern Pecos County has decreased over the years because ground-water withdrawals have lowered water levels below solution channels that comprise the zones of greatest hydraulic conductivity.

Trinity strata in the Trans-Pecos include the basal Cretaceous sand and, in southern parts of Pecos and Terrell Counties, the Glen Rose Limestone and Maxon Sand (fig. 8). The Trinity Group generally is less than $500 \mathrm{ft}$ thick in the Trans-Pecos, where much of it is unsaturated or marginally permeable. The availability of ground water from the Trinity Group largely remains untested in Terrell County, and the Maxon Sand and upper few hundred feet of Glen Rose Limestone generally are not saturated in Brewster County. Neither the Glen Rose Limestone nor the Maxon Sand is present in Reeves County, and the hydrologic aspects of the basal Cretaceous sand have not been distinguished from that of other Cretaceous strata in this area (Ogilbee and others, 1962, p. 27). Although the basal Cretaceous sand is only about $150 \mathrm{ft}$ thick near Fort Stockton (fig. 11), this coarse-grained, quartzose unit is an important source of ground water in Pecos County (Armstrong and McMillion, 1961, p. 57, 62). The basal Cretaceous sand yields as much as $500 \mathrm{gal} / \mathrm{min}$ of water to individual industrial-, irrigation-, and public-supply wells in Pecos County.

The Edwards-Trinity aquifer is connected hydraulically to the Cenozoic Pecos alluvium, which fills two structural troughs in parts of Crane, Loving, Pecos, Reeves, Ward, and Winkler Counties (fig. 2). The troughs formed as large volumes of salt dissolved from deeply buried Permian rocks (Maley and Huffington, 1953), and much of the overlying Permian, Triassic, and Cretaceous strata collapsed and was transported from the area by the ancestral Pecos River. The alluvium predominately is an unconsolidated to semi-consolidated mixture of gravel, sand, silt, clay, and caliche. Although the alluvium is highly permeable in most areas, its hydraulic conductivity varies greatly because of differences in the degrees of sorting and consolidation. Where the alluvium is saturated and permeable, it comprises the Cenozoic Pecos alluvium aquifer (Texas 
Water Development Board, 1990, fig. 1-1). Where the sediments are strongly cemented with hardpan (a calcareous precipitate), ground water frequently is perched above the regional potentiometric surface. The Cenozoic Pecos alluvium aquifer (fig. 2) is the primary source of water for irrigation in northern Reeves and northwestern Pecos Counties (Ashworth, 1990, p. 12).

The Cenozoic Pecos alluvium rests on Permian and Triassic red beds in northern Reeves County, where the alluvium in places is greater than $1,500 \mathrm{ft}$ thick (pl. 2). Thinner deposits cover the north-facing flank of the southernmost trough, whose floor is composed of Cretaceous strata of the Edwards-Trinity aquifer (Ashworth, 1990, figs. 3, 5). Because the Cenozoic Pecos alluvium is connected hydraulically to the EdwardsTrinity aquifer, the base of the alluvium is considered the base of the regional ground-water-flow system where the Edwards-Trinity rocks are absent (Barker and Ardis, 1992).

The Edwards-Trinity aquifer overlies the Dockum Group of Triassic age in parts of Pecos and Reeves Counties (pl. 2). The upper part of the Dockum Group is absent in some areas, causing sand of the Dockum aquifer (middle part of the Dockum Group) to merge with the basal Cretaceous sand of the Edwards-Trinity aquifer (fig. 2). In these areas, the depth of regional ground-water flow might increase a few hundred feet below the base of the Edwards-Trinity aquifer system (Barker and Ardis, 1992). The Dockum aquifer has been a major source of public-supply water in northeastern Reeves County, where it also provides some water for livestock.

Although the Dockum aquifer directly underlies the Edwards-Trinity aquifer in northwestern Crockett and northeastern Reeves Counties, the extent and importance of the Dockum aquifer is uncertain across most of Pecos County (fig. 2). The Edwards-Trinity aquifer is directly underlain in this area by Permian and Triassic red beds that have not been differentiated (pls. 2,5). The uppermost Permian rock unit is a red siltstone, cemented with gypsum and calcite, that resembles the lower part of the overlying Dockum Group. (The lower part of the Dockum Group is composed largely of reworked Upper Permian strata.) The undifferentiated red beds in Pecos County range from zero to about $1,500 \mathrm{ft}$ thick; however, no part of the interval appears to be a particularly viable source of potable ground water. According to Armstrong and McMillion (1961, p. 37), the red beds of Permian and Triassic age yield "*** small amounts of water at various locations." Where the middle Dockum unit is present in Pecos County, it probably is thinner and less permeable than the Dockum aquifer of adjacent counties.
The Trans-Pecos aquifers primarily are recharged through the infiltration of storm runoff resulting from precipitation on the northern flanks of the Barilla, Davis, and Glass Mountains and on the eastern flanks of the Apache and Delaware Mountains (fig. 3). The headwaters of the streams that drain these mountains mostly are confined to narrow channels with nearly impervious streambeds. The high-gradient headwater channels empty into comparatively low-gradient arroyos atop porous alluvial fans at the base of the mountains. During prolonged storms, runoff fills the mountain channels and flows into the arroyos, from which water percolates to the Edwards-Trinity and Cenozoic Pecos alluvium aquifers.

Considerable recharge takes place in south-central Pecos County where the arroyos traverse coarse alluvium that overlies cavernous limestone of the EdwardsTrinity aquifer. Sinkholes in the limestone greatly expedite the recharge process (Armstrong and McMillion, 1961, p. 46; pl. 14). Some recharge might occur as lateral subsurface inflow from strata deep within the mountains in northern Brewster and Jeff Davis Counties. However, such inflow is considered unlikely because these strata are faulted, folded, and tilted to the extent that flow through them probably would be impeded, if not blocked entirely (Rees and Buckner, 1980, fig. 3). Much of the springflow in the Balmorhea area of Reeves County (fig. 3) that follows prolonged periods of precipitation has been traced to the infiltration of precipitation and storm runoff in a narrow anticlinal valley along the eastern escarpment of the Davis Mountains (White and others, 1941, p. 112). The results of more recent geochemical analyses by LaFave and Sharp (1987) indicate that a substantial part of the sustained (long-term) recharge to these springs might originate from relatively remote locations in and near the Apache Mountains.

Recharge has been induced in parts of the TransPecos as a result of water-level decline caused by the withdrawal of water for irrigation. In response to waterlevel decline in the Cenozoic Pecos alluvium aquifer, hydraulic gradients between the Pecos River and the aquifer have reversed from their predevelopment direction in parts of Pecos (Armstrong and McMillion, 1961, p. 52) and Reeves Counties (Ogilbee and others, 1962, p. 33). The Pecos River now loses streamflow to the aquifer in parts of northwestern Pecos and northcentral Reeves Counties, where the aquifer originally discharged to the river. Leakage from the Pecos River is not necessarily beneficial to the aquifer, as the concentrations of chloride and dissolved solids in this stream can exceed 5,000 and $15,000 \mathrm{mg} / \mathrm{L}$, respectively (Grozier and others, 1966). 
Although water levels declined more than $200 \mathrm{ft}$ in parts of Reeves County and more than $100 \mathrm{ft}$ in parts of Pecos County, decreasing rates of ground-water withdrawal since the mid-1960's have allowed water levels to recover as much as $75 \mathrm{ft}$ in some wells (Bush and others, 1993). The reductions in irrigation pumpage occurred in response to (1) greater-thannormal precipitation during much of 1966-90; (2) fuel and labor costs that began to escalate during the 1970's; and (3) depressed profits in the agricultural marketplace during the last 30 years. An undetermined fraction of the irrigation water in shallow water-table areas percolates back to the saturated zone, thereby reducing the effects of ground-water withdrawal in some lowlying areas of the Trans-Pecos. Despite this return flow and the decreasing rates of withdrawal, water-level hydrographs indicate that water levels have not returned to predevelopment levels in Pecos County (Small and Ozuna, 1993); nor have water levels recovered fully in Reeves County (Sharp, 1989, p. 129).

Whereas well withdrawals in the Trans-Pecos were negligible through about 1945, withdrawal rates accelerated along with agricultural expansion following World War II. Between about 1946 and the late 1950's, the number of irrigation-supply wells increased annually by almost 25 percent. Pumpage in Pecos and Reeves Counties from the Cenozoic Pecos alluvium and Edwards-Trinity aquifers, combined, increased to about 550,000 acre-ft/yr by the late 1950's (Armstrong and McMillion, 1961, p. 44; Ogilbee and others, 1962, p. 34). Owing in part to economic pressures and water conservation since the mid-1960's, pumpage from the Edwards-Trinity aquifer alone decreased to about 450,000 acre-ft/yr by 1975-76. All but about 1,600 acre$\mathrm{ft} / \mathrm{yr}$ of the 1975-76 pumpage occurred in Pecos and Reeves Counties, where about 95 percent of the water was used for irrigation (Lurry and Pavlicek, 1991). Ground-water withdrawals from the Edwards-Trinity aquifer in the Trans-Pecos have continued to decrease-to about 60,000 acre-ft/yr during 1990 or less than 15 percent of the 1975-76 rate (D.L. Lurry, U.S. Geological Survey, written commun., 1992).

Springflow from the Trans-Pecos aquifers has decreased substantially as the result of water-level declines caused by ground-water withdrawals for irrigation. Although the combined springflow in Pecos and Reeves Counties averaged nearly 85,000 acre-ft/yr during the mid-1940's (Armstrong and McMillion, 1961, p. 43-44; Ogilbee and others, 1962, p. 28), this springflow averaged less than $40,000 \mathrm{acre}-\mathrm{ft} / \mathrm{yr}$ during the 1980 's. Before 1946, about 48,000 acre-ft/yr of water discharged from springs in Pecos County; by 1958, this discharge had decreased to less than 2,000 acre-ft/yr (Armstrong and McMillion, 1961, p. 47). Despite short- term surges in springflow during 1986-88 (Small and Ozuna, 1993, fig. 13), springflow has been negligible in Pecos County since 1961.

The development of ground water in the TransPecos has reduced the loss of ground water to evapotranspiration. Increases in the depth of water below land surface have reduced the consumptive use by phreatophytes. Evapotranspiration losses to phreatophyte growth is locally important in the Pecos River valley, where the tap roots of salt cedar, mesquite, and alfalfa can exceed $50 \mathrm{ft}$ in length.

Transmissivity values for the Edwards-Trinity aquifer are difficult to obtain and highly variable; fewer than 10 values from the results of aquifer tests are reported for Pecos and Reeves Counties (Armstrong and McMillion,1961; Ogilbee and others, 1962). Transmissivity values reported for thicker parts of the Cenozoic Pecos alluvium in north-central Reeves County are as large as $20,000 \mathrm{ft}^{2} / \mathrm{d}$ (Ogilbee and others, 1962 , p. 37). Although the transmissivity of Fredericksburg strata that contain a large number of solution channels in west-central Pecos County is unknown, the results of aquifer tests in relatively unaltered carbonate strata of the same age indicate values of less than $1,000 \mathrm{ft}^{2} / \mathrm{d}$. The analyses of drawdown and recovery data from wells completed in the basal Cretaceous sand provide transmissivity values ranging from about 500 to $1,000 \mathrm{ft}^{2} / \mathrm{d}$.

\section{GONFINING UNITS}

The characteristics of the two regional confining units are summarized below. The summary begins with the Navarro-Del Rio confining unit, the easternmost and most massive confining unit in the aquifer system.

\section{NAVARRO-DEL RIO CONFINING UNIT}

The Navarro-Del Rio confining unit confines downdip parts of the Edwards aquifer in the Balcones fault zone (fig. 2; pls. 3, 7). From top to bottom, this confining unit includes the Navarro Group, Taylor Group, Austin Group, Eagle Ford Group, Buda Limestone, and Del Rio Clay. According to Baker and others $(1986$, p. 9), these rock units "**** yield little or no water or a very small amount of water to mostly shallow dug wells." Together, these units form a regional barrier to vertical ground-water flow. Although these strata are displaced vertically in the Balcones fault zone, their combined thickness typically exceeds $1,200 \mathrm{ft}$, or nearly 10 times the maximum thickness of the Hammett confining unit (table 2). Despite the vertical displacement of its individual parts, the rock sequence as a whole is regionally continuous within the fault zone, so that the 
Navarro-Del Rio confining unit effectively confines water within the Edwards aquifer (Baker and others, 1986, fig. 16; Maclay and Small, 1986, fig. 11).

Thin, scattered remnants of the Del Rio Clay and Buda Limestone, plus minor outcrops of Gulf strata, overlie the Edwards-Trinity aquifer system in parts of the Edwards Plateau and Trans-Pecos. None of these rock units is known to yield significant amounts of ground water. However, they are not regarded as confining units west of the Balcones fault zone, where they are discontinuous and not underlain directly by saturated rock.

\section{HAMMETT CONFINING UNIT}

The Hammett confining unit is composed of the Hammett Shale, a blanketlike deposit of dark calcareous and dolomitic shale, with finely laminated interbeds of limestone and sand (Ashworth, 1983, p. 27). The Hammett confining unit is restricted to most of the Hill Country and a small southeastern part of the Edwards Plateau where structural disruption of the hydraulically tight Hammett Shale has been minor (pls. 3, 7, 8). From negligible thickness on the southern flank of the Llano uplift (fig. 8), the Hammett confining unit gradually thickens in a downdip direction to more than $80 \mathrm{ft}$ thick in northern Medina and northeastern Uvalde Counties (fig. 21). The unit generally varies between 40 and $60 \mathrm{ft}$ thick in the Hill Country (Amsbury, 1974, p. 18). Because of its plastic consistency, the shale typically will slide into the bore of an uncased well. Therefore, boreholes through the unit must be cased and grouted within a few hours of being drilled (D.A. Muller, Texas Water Development Board, oral commun., 1990). Vertical displacement of the Pine Island Shale Member of the Pearsall Formation probably prevents this downdip equivalent of the Hammett Shale from being an effective regional confining unit within the Balcones fault zone.

\section{SUMMARY}

The Edwards-Trinity aquifer system, which underlies about $42,000 \mathrm{mi}^{2}$ of west-central Texas, is composed of nearly flat-lying carbonate strata of Comanchean (mostly Early Cretaceous) and Gulfian (Late Cretaceous) age. The Cretaceous rocks of the aquifer system thin toward the northwest atop generally massive, comparatively impermeable and structurally complex preCretaceous rocks. From predominately terrigenous clastic sediments in the east and terrestrial deposits in the west, the rocks of early Trinitian (Comanchean) age grade upward into supratidal and intertidal evaporitic and dolomitic rocks and shallow-marine, lagoonal, and basinal carbonate strata of late Trinitian, Fredericksburgian, and Washitan (Comanchean) age. A thick, downfaulted remnant of mostly open-shelf sediments of Eaglefordian through Navarroan (Gulfian) age confines a small, southeastern part of the aquifer system.

The regional aquifer system contains three aquifers: (1) the Edwards aquifer in the Balcones fault zone; (2) the Trinity aquifer in the Balcones fault zone and Hill Country; and (3) the Edwards-Trinity aquifer in the Edwards Plateau and Trans-Pecos. The aquifers are laterally adjacent except in the Balcones fault zone, where a downfaulted part of the Trinity aquifer is overlain by the Edwards aquifer. The permeable strata mainly result from fractures and joint cavities, solution channels, and fabric-selective forms of porosity caused by the dissolution of evaporites, other soluble minerals, and assorted allochems.

The aquifer system contains two regional confining units. The Navarro-Del Rio confining unit confines downdip parts of the Edwards aquifer in the Balcones fault zone. The Hammett confining unit confines basal parts of the Trinity and Edwards-Trinity aquifers in the Hill Country and Edwards Plateau, respectively. The confining units mostly are composed of calcareous mudstone, siltstone, and shale.

The depositional, tectonic, and diagenetic characteristics of the Cretaceous rocks of the Edwards-Trinity aquifer system are strikingly different from those of the underlying pre-Cretaceous rocks. The typically medium- to thin-bedded Cretaceous strata of the aquifer system mostly dip southeastward atop generally massive, westward-dipping Paleozoic and Triassic units. The unconformity between the Cretaceous rocks of the aquifer system and the pre-Cretaceous complex marks a major shift in the geologic evolution of the study area. This hiatus in the rock record spans about 60 million years of crustal warping and erosion between the deposition of terrestrial red beds during Late Triassic time and the deposition of terrigenous clastic and shallow-marine carbonate sediments during Early Cretaceous time.

The Early Cretaceous sea encroached slowly westward upon a rolling peneplain of folded and faulted pre-Cretaceous rocks. While alluvial plains inland of the transgressing sea were dominated by clastic deposition, shallow offshore environments-characterized by warm, generally clear seawater-promoted the biogenic accumulation of calcium carbonate.

Trinity deposition was characterized by a cyclic pattern of shoreline advance and retreat superimposed upon an overall pattern of marine transgression. The resulting lithofacies are diachronous toward the Llano uplift and reflect the effects of shallower water and shoreline advancement toward the 
northwest. The Trinity strata were deposited during three transgressive-regressive cycles of sedimentation. These cycles consist of the (1) Sycamore Sand (Hosston Formation, downdip) and Sligo Formation; (2) Hammett Shale (Pine Island Shale Member, downdip) and Cow Creek Limestone (Cow Creek Limestone Member, downdip); and (3) Hensel Sand (Bexar Shale Member, downdip) and Glen Rose Limestone. The basal Cretaceous sand and Maxon Sand were deposited in fluvialdeltaic settings west of the Llano uplift.

The Fredericksburg and lower Washita strata of westcentral Texas were deposited upon the Comanche shelf, a carbonate platform sheltered by the Stuart City reef trend from storm waves and deep ocean currents in the ancestral Gulf of Mexico. Depositional environments were controlled by the (1) distribution and rates of subsidence and uplift, (2) influx of fine-grained terrigenous sediment, and (3) extent of water circulation, or degree of restriction relative to that of the open sea. The Kainer and Person Formations formed over the San Marcos arch, a structural high dominated by tidal flats that frequently underwent uplift, subaerial exposure, and erosion. The eastern part of the Fort Terrett Formation and the Segovia Formation formed near the crest of the central Texas platform mostly in supratidal to restricted shallow-marine environments. The western part of the Fort Terrett Formation and the Fort Lancaster Formation formed mostly in open shallow-marine to openshelf environments transitional to the central Texas platform and Fort Stockton basin. The Finlay Formation formed in the Fort Stockton basin, when the basin primarily was a broad, open lagoon; the Boracho Formation was deposited later in a deeper, shelf-basin environment. The West Nueces, McKnight, and Salmon Peak Formations formed within the persistently submerged Maverick basin. The depositional environments inside the Maverick basin generally were buffered from those on the central Texas platform by the intervening Devils River trend, in which the Devils River Formation formed.

During late Oligocene through early Miocene time, large-scale normal faulting created the Balcones fault zone, where the Cretaceous strata were displaced vertically, fractured intensively, and rotated differentially within a series of southwest-to-northeast trending fault blocks. Ground-water flow shifted toward the northeast in response to rejuvenated hydraulic gradients in that direction and high-angle barrier faults that blocked the older southeastward flowpaths. New flowpaths developed subparallel to the strike of the fault zone as evaporites and soluble calcareous constituents dissolved from the fractured strata and discharged to downgradient springs and streams. Springs originated in topographically low areas where barrier faults intercepted confined water at depth and diverted it to the surface. Ground-water conduits enlarged through carbonate dissolution along flowpaths that converged toward the springs. The major springs persisted to control modern potentiometric levels and discharge patterns. Stream erosion eventually breached the overlying, low-permeability Gulf rocks and provided discharge areas for aquifers in the underlying, more permeable Comanche rocks.

The Balcones faulting triggered processes responsible for sizable contrasts between the hydraulic characteristics of the Edwards aquifer and those of the Trinity and Edwards-Trinity aquifers. The faulting increased hydraulic gradients in the fault zone, which enhanced the percolation of meteoric water from land surface and increased the velocity of shallow ground-water flow. A dynamic regime of shallow ground-water flow evolved that promoted dissolution. Dissolution along fractures and bedding planes formed joint cavities and solution channels that became the principal conduits of regional ground-water flow in the Edwards aquifer.

The rocks in the Hill Country, Edwards Plateau, and Trans-Pecos mostly were excluded from the large-scale normal faulting, intensive fracturing, and subsequent dissolution that controlled the origin of the Edwards aquifer in the Balcones fault zone. Consequently, the hydraulic characteristics of the Trinity and EdwardsTrinity aquifers more closely resemble those of each other than those of the Edwards aquifer. As the transmissivity of the Edwards aquifer increased over geologic time, cementation, recrystallization, and replacement resulting from deep burial and comparatively sluggish ground-water movement combined to diminish the transmissivity of the Trinity and EdwardsTrinity aquifers.

The saturated thickness of the aquifer system ranges from more than $500 \mathrm{ft}$ in the southern part of the aquifer system to less than $100 \mathrm{ft}$ near the northern part. The saturated thickness is more than $500 \mathrm{ft}$ throughout the Balcones fault zone and over the southeastern twothirds of the Hill Country. The saturated thickness decreases to less than $100 \mathrm{ft}$ over the northwestern third of the Hill Country where the Trinity aquifer thins against Precambrian rocks of the Llano uplift. In the Edwards Plateau, the saturated thickness grades from more than $500 \mathrm{ft}$ in the southern one-half of the area to less than $100 \mathrm{ft}$ along the northern margin. In the TransPecos, the saturated thickness ranges over short distances from more than $500 \mathrm{ft}$ to less than $100 \mathrm{ft}$, reflecting the rugged relief at the base of the aquifer system.

The Edwards aquifer in the Balcones fault zone is one of the most productive subsurface reservoirs of potable water in the world. The Edwards aquifer is recognized as the sole source of ground water in the San Antonio 
area, where it serves the domestic, public-supply, industrial, and agricultural needs of more than a million people and sustains several threatened or endangered plant and animal species. The Edwards aquifer lies within the Georgetown, Person, and Kainer Formations in the northeastern part of the fault zone and within the Devils River, West Nueces, McKnight, and Salmon Peak Formations in the southwestern part. Ground-water flow largely is controlled by an anisotropic pattern of hydraulic conductivity and a dominant southwestto-northeast component of transmissivity, both of which result from barrier faults, fractures, joint cavities, and solution channels that are aligned with the fault zone. Transmissivity ranges from about 10,000 to more than $5,000,000, \mathrm{ft}^{2} / \mathrm{d}$ and probably averages about $750,000 \mathrm{ft}^{2} / \mathrm{d}$. After steadily increasing from about 100,000 acre-ft/yr during the 1930 's to an average 470,000 acre-ft/yr during the 1980's, ground-water withdrawals recently have tapered to an average 420,000 acre-ft/yr during 1990-93. Although water levels and springflows periodically are reduced by lessthan-normal recharge and (or) greater-than-normal pumpage caused by drought, long-term hydrographs for the San Antonio area indicate no net decline (or rise) in water levels over the last 80 years.

The Trinity aquifer, composed entirely of Trinity strata in the Balcones fault zone and Hill Country, dominates the ground-water hydrology of the Hill Country, where most Fredericksburg and practically all Washita strata are absent. Strongly cemented, hydraulically tight interbeds in the upper and middle parts of the Trinity aquifer impede the downward percolation of precipitation. Ground water in the interstream areas commonly is perched above the regional ground-water-flow system and the base level of adjacent streams. Meteoric water that infiltrates the interstream areas moves laterally atop the dense interbeds more readily than it percolates vertically through them. Ground water emerges from springs and seeps along the tops of the impermeable bedding where the bedding is breached by the topography. Thus, instead of percolating to deeper permeable zones, much of the water in shallow parts of the Trinity aquifer discharges to the deeply entrenched, perennial streams that drain the Hill Country. Streamflow gains in the Hill Country subsequently are lost in the downstream Balcones fault zone where the streams cross faults onto permeable streambeds in the outcrop area of the Edwards aquifer. Water also discharges from the Trinity aquifer through wells and as lateral subsurface inflow and diffuse upward leakage to the Edwards aquifer. Ground-water withdrawals from the Trinity aquifer have remained relatively stable since the mid1970 's, averaging between 10,000 and 15,000 acre-ft/yr during 1975-76 and totaling about 13,500 acre-ft during
1990. Long-term hydrographs indicate that water levels can vary greatly over short periods, typically varying 50 $\mathrm{ft}$ or more between winter highs and summer lows. The Trinity aquifer generally is affected by drought more quickly than the Edwards aquifer. Transmissivity ranges from less than 1,000 to about $50,000 \mathrm{ft}^{2} / \mathrm{d}$ and appears to average less than $10,000 \mathrm{ft}^{2} / \mathrm{d}$.

The Edwards-Trinity aquifer in the Edwards Plateau includes all the Fredericksburg and Trinity strata plus all Washita rocks below the Del Rio Clay or the Buda Limestone. Washita and Fredericksburg rocks provide the principal water-producing zones in the Edwards Plateau, except where these rocks are breached along the valleys of the Concho, Guadalupe, Llano, Pecos, Pedernales, and San Saba Rivers. Along these valleys, middle and lower Trinity rock units supplement stream-valley alluvium as major sources of ground water. The basal Cretaceous sand is an important waterproducing unit in northwestern parts of the area and along the Pecos River valley where the Washita and Fredericksburg rocks have been removed by erosion. Water-producing zones in the Edwards Plateau mostly are confined or semi-confined, except in the shallowest zones and near the outer margins of Fredericksburg strata where the Trinity sediments crop out. From generally unconfined or semi-confined conditions in the west, the Edwards-Trinity aquifer becomes progressively more confined toward the southeast. Since 1975-76, when ground-water withdrawals averaged nearly 130,000 acre-ft/yr, pumpage has fluctuated between about 85,000 acre-ft (during 1985) and about 128,000 acre-ft (1990). Water-level hydrographs for central parts of the Edwards Plateau reflect a cyclic relation between recharge and precipitation: (1) declining water levels during most of the 1960's, when precipitation was below normal; (2) rising water levels during most of the 1970's, when precipitation was above normal; and (3) declining water levels during most of the 1980's, when precipitation was below normal. Many of the highest recorded water levels during the past 30 years in Crockett, Edwards, Kimble, Schleicher, and Sutton Counties occurred during the middle-to-late 1970's. Although transmissivity probably is less than 5,000 $\mathrm{ft}^{2} / \mathrm{d}$ over most of the Edwards Plateau, it probably averages about $10,000 \mathrm{ft}^{2} / \mathrm{d}$ in southern parts of the area, where the Cretaceous sediments are thickest.

The Edwards-Trinity aquifer in the Trans-Pecos includes all the Fredericksburg and Trinity strata plus all Washita rocks below the Del Rio Clay or the Buda Limestone. The structural complexity of the Trans-Pecos results from the collapse of Permian rocks that underlie much of the area and crustal deformation during Cenozoic time. Water from the Edwards-Trinity aquifer is supplemented locally by water from the Cenozoic Pecos 
alluvium aquifer and the Dockum aquifer. Water levels and springflow declined in response to accelerating rates of ground-water withdrawal following World War II. From negligible pumpage before 1945, pumpage from the Cenozoic Pecos alluvium and Edwards-Trinity aquifers, combined, increased to about 550,000 acre$\mathrm{ft} / \mathrm{yr}$ by the late 1950 's. Although water levels declined more than $200 \mathrm{ft}$ in parts of the Trans-Pecos, decreasing withdrawals since the mid-1960's have allowed water levels to recover as much as $75 \mathrm{ft}$ in some wells. Pumpage from the Edwards-Trinity aquifer, alone, decreased from about 450,000 acre-ft/yr during the mid-1970's to about 60,000 acre-ft during 1990. Springflow decreased from an average of nearly $85,000 \mathrm{acre}-\mathrm{ft} / \mathrm{yr}$ during the mid-1940's to less than 40,000 acre-ft/yr during the 1980 's. Transmissivity values for the Edwards-Trinity aquifer are difficult to obtain and highly variable in the Trans-Pecos. Although transmissivity values as large as $20,000 \mathrm{ft}^{2} / \mathrm{d}$ are reported for thicker parts of the Cenozoic Pecos alluvium, values of less than $1,000 \mathrm{ft}^{2} / \mathrm{d}$ are indicated for relatively unaltered carbonate strata of Fredericksburgian age. Transmissivity in the basal Cretaceous sand ranges from about 500 to $1,000 \mathrm{ft}^{2} / \mathrm{d}$.

\section{SELECTED REFERENGES}

Abbott, P.L., 1975, On the hydrology of the Edwards Limestone, south-central Texas: Journal of Hydrology, v. 24, p. 251-269.

1977, Effect of Balcones faults on groundwater movement, south central Texas: Texas Journal of Science, v. 29, no. 1 and 2, p. 5-14.

Adkins, W.S., 1933, The Mesozoic Systems in Texas, in The geology of Texas, v. I, Stratigraphy: Austin, University of Texas, Bureau of Economic Geology Bulletin 3232, p. 239-518.

Amsbury, D.L., 1974, Stratigraphic petrology of Lower and Middle Trinity rocks on the San Marcos platform, south-central Texas, in Perkins, B.F., ed., Aspects of Trinity division geology-a symposium: Louisiana State University, Geoscience and Man, v. 8, p. 1-35.

Ardis, A.F., and Barker, R.A., 1993, Historical saturated thickness of the Edwards-Trinity aquifer system and selected contiguous hydraulically connected units, west-central Texas: U.S. Geological Survey Water-Resources Investigations Report 92-4125, 2 sheets.

Armstrong, C.A., and McMillion, L.G., 1961, Geology and groundwater resources of Pecos County, Texas: Texas Board of Water Engineers Bulletin 6106, v. I, 241 p.

Arnow, Ted, 1963, Ground-water geology of Bexar County, Texas: U.S. Geological Survey Water-Supply Paper 1588, 36 p.

Ashworth, J.B., 1983, Ground-water availability of the Lower Cretaceous formations in the Hill Country of south-central Texas: Texas Department of Water Resources Report 273, 173 p.

-1990, Evaluation of ground-water resources in parts of Loving, Pecos, Reeves, Ward, and Winkler Counties, Texas: Texas Water Development Board Report 317, 51 p.

Ashworth, J.B., and Christian, P.C., 1989, Evaluation of ground-water resources in parts of Midland, Reagan, and Upton Counties, Texas: Texas Department of Water Resources Report 312, 52 p.
Ashworth, J.B., and Flores, R.R., 1991, Delineation criteria for the major and minor aquifer maps of Texas: Texas Water Development Board Report LP-212, 27 p.

Back, William, Hanshaw, B.B., Plummer, L.N., Rahn, P.H., Rightmire, C.T., and Rubin, Meyer, 1983, Process and rate of dedolomitization-mass transfer and ${ }^{14} \mathrm{C}$ dating in a regional carbonate aquifer: Geological Society of America Bulletin, v. 94, no. 12, p. $1,415-1,429$.

Bader, R.W., Walthour, S.D., and Waugh, J.R., 1993, Edwards aquifer hydrogeologic status report for 1992: Edwards Underground Water District Report 93-05, $71 \mathrm{p}$.

Baker, E.T., Jr., Slade, R.M., Jr., Dorsey, M.E., Ruiz, L.M., and Duffin, G.L., 1986, Geohydrology of the Edwards aquifer in the Austin area, Texas: Texas Water Development Board Report 293, 217 p.

Barker, R.A., and Ardis, A.F., 1992, Configuration of the base of the Edwards-Trinity aquifer system and hydrogeology of the underlying pre-Cretaceous rocks, west-central Texas: U.S. Geological Survey Water-Resources Investigations Report 91-4071, 25 p.

Bathurst, R.G.C., 1975, Carbonate sediments and their diagenesis: Amsterdam, Elsevier, 658 p.

Bay, T.A., Jr., 1977, Lower Cretaceous models from Texas and Mexico, in Bebout, D.G., and Loucks, R.G., eds., Cretaceous carbonates of Texas and Mexico, applications to subsurface exploration: Austin, University of Texas, Bureau of Economic Geology Report of Investigations 89, p. 12-30.

Bebout, D.G., 1977, Sligo and Hosston depositional patterns, subsurface of south Texas, in Bebout, D.G., and Loucks, R.G., eds., Cretaceous carbonates of Texas and Mexico, applications to subsurface exploration: Austin, University of Texas, Bureau of Economic Geology Report of Investigations 89, p. 79-96.

Bebout, D.G., Budd, D.A., and Schatzinger, R.A., 1981, Depositional and diagenetic history of the Sligo and Hosston Formations (Lower Cretaceous) in south Texas: Austin, University of Texas, Bureau of Economic Geology Report of Investigations 109, 70 p.

Bebout, D.G., and Loucks, R.G., 1974, Stuart City trend, Lower Cretaceous, South Texas-a carbonate shelf-margin model for hydrocarbon exploration: Austin, University of Texas, Bureau of Economic Geology Report of Investigations 78, $80 \mathrm{p}$.

Bedinger, M.S., and Emmett, L.F., 1963, Mapping transmissibility of alluvium in the lower Arkansas River Valley, Arkansas, in Short papers in geology and hydrology: U.S. Geological Survey Professional Paper 475-C, p. C188-C190.

Brand, J.P., and Deford, R.K., 1958, Comanchean stratigraphy of Kent quadrangle, Trans-Pecos Texas: American Association of Petroleum Geologists Bulletin, v. 42, no. 2, p. 371-386.

Brune, Gunnar, and Duffin, G.L., 1983, Occurrence, availability, and quality of ground water in Travis County, Texas: Texas Department of Water Resources Report 276, $219 \mathrm{p}$.

Bush, P.W., Ardis, A.F., and Wynn, K.H., 1993, Historical potentiometric surface of the Edwards-Trinity aquifer system and contiguous hydraulically connected units, west-central Texas: U.S. Geological Survey Water-Resources Investigations Report $92-4055,3$ sheets.

Butterworth, R.A., 1970, Sedimentology of the Maxon Formation (Cretaceous), west Texas: Austin, University of Texas, unpub. M.A. thesis, $132 \mathrm{p}$.

Carr, J.T., Jr., 1967, The climate and physiography of Texas: Texas Water Development Board Report 53, 27 p.

Carr, M.M., 1987, Facies and depositional environments of the Lower Cretaceous McKnight Formation evaporites, Maverick basin, southwest Texas: Arlington, Tex., University of Texas, unpub. M.S. thesis, $144 \mathrm{p}$.

Choquette, P.W., and Pray, L.C., 1970, Geologic nomenclature and classification of porosity in sedimentary carbonates: 
American Association of Petroleum Geologists Bulletin, v. 54, no. 2, p. 207-250.

Collins, E.W., 1995, Structural framework of the Edwards aquifer, Balcones fault zone, central Texas: Transactions of the Gulf Coast Association of Geological Societies, v. 45, p. 135-142.

DeCook, K.J., 1963, Geology and ground-water resources of Hays County, Texas: U.S. Geological Survey Water-Supply Paper 1612, $72 \mathrm{p}$.

De Groot, K., 1967, Experimental dedolomitization: Journal of Sedimentary Petrology, v. 37, p. 1,216-1,220.

Duffin, G.L., 1974, Subsurface saline water resources in the San Antonio area, Texas: Texas Water Development Board Open-File Report, $39 \mathrm{p}$.

Dunham, R.J., 1962, Classification of carbonate rocks according to depositional texture, in Classification of carbonate rocks symposium: American Association of Petroleum Geologists Memoir 1, p. 108-121.

Ellis, Patricia, 1986, Post-Miocene carbonate diagenesis of the Lower Cretaceous Edwards Group in the Balcones fault zone area, south-central Texas, in Abbott, P.L., and Woodruff, C.M., Jr., eds., The Balcones escarpment, geology, hydrology, ecology and social development in central Texas: Geological Society of America, p. 101-114.

Evamy, B.D., 1967, Dedolomitization and the development of rhombohedral pores in limestones: Journal of Sedimentary Petrology, v. 37, p. $1,204-1,215$.

Ewing, T.E., 1991, The tectonic framework of Texas, with accompanying tectonic map of Texas: Austin, University of Texas, Bureau of Economic Geology, $36 \mathrm{p}$.

Fenneman, N.M., 1931, Physiography of western United States: New York, McGraw-Hill, $534 \mathrm{p}$.

Fisher, W.L., and Rodda, P.U., 1966, Nomenclature revision of basal Cretaceous rocks between the Colorado and Red Rivers, Texas: Austin, University of Texas, Bureau of Economic Geology Report of Investigations 58, p. 1-20.

Flawn, P.T., 1956, Basement rocks of Texas and southeast New Mexico: Austin, University of Texas, Bureau of Economic Geology Publication 5605, $261 \mathrm{p}$.

1964, Basement rocks of the Texas Gulf Coastal Plain: Transactions of the Gulf Coast Association of Geological Societies, v. 14, p. 271-275.

Flawn, P.T., Goldstein, August, Jr., King, P.B., and Weaver, C.E., 1961, The Ouachita system: Austin, University of Texas, Bureau of Economic Geology Publication 6120, 401 p.

Folk, R.L., 1962, Practical petrographic classification of limestones: American Association of Petroleum Geologists Bulletin, v. 43, no. 1, p. 1-38.

Forgotson, J.M., Jr., 1956, A correlation and regional stratigraphic analysis of the formations of the Trinity Group of the Comanchean Cretaceous of the Gulf Coastal Plain; and the genesis and petrology of the Ferry Creek Anhydrite: Transactions of the Gulf Coast Association of Geological Societies, v. 6, p. 91-108.

1957, Stratigraphy of Comanchean Cretaceous Trinity Group: American Association of Petroleum Geologists Bulletin, v. 41, no. 10, p. $2,328-2,363$.

Grozier, U.R., Albert, H.W., Blakey, J.F., and Hembree, C.H., 1966, Water-delivery and low-flow studies, Pecos River, Texas, quantity and quality, 1964 and 1965: Texas Water Development Board Report 22, $21 \mathrm{p}$.

Gutentag, E.D., Heimes, F.J., Krothe, N.C., Luckey, R.R., and Weeks, J.B., 1984, Geohydrology of the High Plains aquifer in parts of Colorado, Kansas, Nebraska, New Mexico, Oklahoma, South Dakota, Texas, and Wyoming: U.S. Geological Survey Professional Paper 1400-B, $63 \mathrm{p}$.
Halley, R.B., and Rose, P.R., 1977, Significance of fresh-water limestones in marine carbonate successions of Pleistocene and Cretaceous age, in Bebout, D.G., and Loucks, R.G., eds., Cretaceous carbonates of Texas and Mexico, applications to subsurface exploration: Austin, University of Texas, Bureau of Economic Geology Report of Investigations 89, p. 206-215.

Hammond, W.W., Jr., 1984, Hydrogeology of the Lower Glen Rose aquifer, south-central Texas: Austin, University of Texas, unpub. Ph.D. dissertation, $245 \mathrm{p}$.

Henry, C.D., and Price, J.G., 1985, Summary of the tectonic development of Trans-Pecos, Texas: Austin, University of Texas, Bureau of Economic Geology Miscellaneous Map 36, 8 p.

Hill, R.T., 1901, Geography and geology of the Black and Grand Prairies, Texas, with detailed descriptions of the Cretaceous formations and special reference to artesian water: U.S. Geological Survey, 21st Annual Report, pt. 7, 666 p.

Hill, R.T., and Vaughan, T.W., 1898, Geology of the Edwards Plateau and Rio Grande Plain adjacent to Austin and San Antonio, Texas, with reference to the occurrence of underground waters: U.S. Geological Survey, 18th Annual Report, pt. 2, p. 193-321.

Hovorka, S.D., Mace, R.E., and Collins, E.W., 1995, Regional distribution of permeability in the Edwards aquifer: Transactions of the Gulf Coast Association of Geological Societies, v. 45, p. 259-265.

Howard, W.V., and David, M.W., 1936, Development of porosity in limestones: American Association of Petroleum Geologists Bulletin, v. 20, no. 11, p. 1,389-1,412.

Humphreys, C.H., 1984, Stratigraphy of the Lower Cretaceous (Albian) Salmon Peak Formation of the Maverick basin, south Texas, in Smith, C.I., ed., Stratigraphy and structure of the Maverick basin and Devils River trend, Lower Cretaceous, southwest Texas-a field guide and related papers: South Texas Geological Society, p. 34-59.

Imlay, R.W., 1945, Subsurface Lower Cretaceous formations of south Texas: American Association of Petroleum Geologists Bulletin, v. 29 , p. 1,416-1,469.

Inden, R.F., 1974, Lithofacies and depositional model for a Trinity Cretaceous sequence, central Texas, in Perkins, B.F., ed., Aspects of Trinity division geology-a symposium: Louisiana State University, Geoscience and Man, v. 8, p. 37-52.

Jacka, A.D., 1977, Deposition and diagenesis of the Fort Terrett Formation (Edwards Group) in the vicinity of Junction, Texas, in Bebout, D.G., and Loucks, R.G., eds., Cretaceous carbonates of Texas and Mexico, applications to subsurface exploration: Austin, University of Texas, Bureau of Economic Geology Report of Investigations 89, p. 182-200.

Jager, E.H., 1942, Pre-Cretaceous topography of western Edwards Plateau, Texas: American Association of Petroleum Geologists Bulletin, v. 26, no. 3, p. 380-386.

Kastning, E.H., 1983, Relict caves as evidence of landscape and aquifer evolution in a deeply dissected carbonate terrain-southwest Edwards Plateau, Texas, U.S.A., in Back, William, and LaMoreaux, P.E., eds., V.T. Stringfield symposium, Processes in karst hydrology: Journal of Hydrology, v. 61, p. 89-112.

1986, Cavern development in the New Braunfels area, central Texas, in Abbott, P.L., and Woodruff, C.M., Jr., eds, The Balcones escarpment, geology, hydrology, ecology and social development in central Texas: Geological Society of America, p. 91-100.

King, P.B., 1942, Permian of west Texas and southeastern New Mexico: American Association of Petroleum Geologists Bulletin, v. 26 , no. 4 , p. 535-763.

1980, Geology of the eastern part of the Marathon basin, Texas: U.S. Geological Survey Professional Paper 1157, 40 p.

King, P.B., and Beikman, H.M., comps., 1974, Geologic map of the United States, exclusive of Alaska and Hawaii: U.S. Geological Survey, scale 1:250,000, 2 sheets. 
Kozik, H.G., and Richter, D.H., 1979, A petrophysical and petrographic study of the Person complex of fields, Karnes County, Texas, in Rose, P.R., ed., Stratigraphy of the Edwards Group and equivalents, eastern Edwards Plateau, Texas-guidebook for Gulf Coast Association of Geological Societies field trip 1, October 9-10, 1979: South Texas Geological Society, p. 20-38.

Kuniansky, E.L., 1989, Precipitation, streamflow, and base flow in west-central Texas, December 1974 through March 1977 U.S. Geological Survey Water-Resources Investigations Report 88-4218, 2 sheets.

-1990, Potentiometric surface of the Edwards-Trinity aquifer system and contiguous hydraulically connected units, westcentral Texas, winter 1974-75: U.S. Geological Survey WaterResources Investigations Report 89-4208, 2 sheets.

Kuniansky, E.L., and Holligan, K.Q., 1994, Simulations of flow in the Edwards-Trinity aquifer system and contiguous hydraulically connected units, west-central Texas: U.S. Geological Survey Water-Resources Investigations Report 93-4039, $40 \mathrm{p}$.

LaFave, J.I., and Sharp, J.M., Jr., 1987, Origins of ground water discharging at the springs of Balmorhea: West Texas Geological Society Bulletin, v. 26, no. 9, p. 5-14.

LeGrand, H.E., and Stringfield, V.T., 1971, Development and distribution of permeability in carbonate aquifers: Water Resources Research, v. 7, no. 5, p. 1,284-1,294.

Linsley, R.K., Jr., Kohler, M.A., and Paulhus, J.L.H., 1975, Hydrology for engineers: New York, McGraw-Hill, $482 \mathrm{p}$.

Loucks, R.G., 1977, Porosity development and distribution in shoalwater carbonate complexes-subsurface Pearsall Formation (Lower Cretaceous), south Texas, in Bebout, D.G., and Loucks, R.G., eds., Cretaceous carbonates of Texas and Mexico, applications to subsurface exploration: Austin, University of Texas, Bureau of Economic Geology Report of Investigations 89, p. 97-126.

Lozo, F.E., Jr., and Smith, C.I., 1964, Revision of Comanche Cretaceous stratigraphic nomenclature, southern Edwards Plateau, southwest Texas: Transactions of the Gulf Coast Association of Geological Societies, v. 14, p. 285-307.

Lozo, F.E., Jr., and Stricklin, F.L., Jr., 1956, Stratigraphic notes on the outcrop basal Cretaceous, central Texas: Transactions of the Gulf Coast Association of Geological Societies, v. 6, p. 67-78.

Lurry, D.L., and Pavlicek, D.J., 1991, Withdrawals from the EdwardsTrinity aquifer system and contiguous hydraulically connected units, west-central Texas, December 1974 through March 1977: U.S. Geological Survey Water-Resources Investigations Report 91-4021, 1 sheet.

Maciay, R.W., and Land, L.F., 1988, Simulation of flow in the Edwards aquifer, San Antonio region, Texas, and refinement of storage and flow concepts: U.S. Geological Survey Water-Supply Paper 2336-A, 48 p.

Maclay, R.W., Rettman, P.L., and Small, T.A., 1980, Hydrochemical data for the Edwards aquifer in the San Antonio area, Texas: Texas Department of Water Resources LP-131, $38 \mathrm{p}$.

Maclay, R.W., and Small, T.A., 1983, Hydrostratigraphic subdivisions and fault barriers of the Edwards aquifer, south-central Texas, U.S.A., in Back, William, and LaMoreaux, P.E., eds., V.T. Stringfield symposium, Processes in karst hydrology: Journal of Hydrology, v. 61, p. 127-146.

1986, Carbonate geology and hydrology of the Edwards aquifer in the San Antonio area, Texas: Texas Water Development Board Report 296, 90 p.

Maley, V.C., and Huffington, R.M., 1953, Cenozoic fill and evaporite solution in the Delaware basin, Texas and New Mexico: Geological Society of America Bulletin, v. 64, no. 5, p. 539-546.

McFarlan, Edward, Jr., 1977, Lower Cretaceous sedimentary facies and sea level changes, U.S. Gulf Coast, in Bebout, D.G., and
Loucks, R.G., eds., Cretaceous carbonates of Texas and Mexico, applications to subsurface exploration: Austin, University of Texas, Bureau of Economic Geology Report of Investigations 89, p. 5-11.

McGowen, J.H., Granata, G.E., and Seni, S.J., 1979, Depositional framework of the Lower Dockum Group (Triassic), Texas Panhandle: Austin, University of Texas, Bureau of Economic Geology Report of Investigations $97,60 \mathrm{p}$.

Miller, B.C., 1984, Physical stratigraphy and facies analysis, Lower Cretaceous, Maverick basin and Devils River trend, Uvalde and Real Counties, Texas, in Smith, C.I., ed., Stratigraphy and structure of the Maverick basin and Devils River trend, Lower Cretaceous, southwest Texas-a field guide and related papers: South Texas Geological Society, p. 3-33.

Mount, J.R., Rayner, F.A., Shamburger, V.M., Jr., Peckam, R.C., and Osborne, F.L., Jr., 1967, Reconnaissance investigation of the ground-water resources of the Colorado River Basin, Texas: Texas Water Development Board Report 51, $107 \mathrm{p}$.

Murray, G.E., 1961, Geology of the Atlantic and Gulf Coastal Province of North America: New York, Harper and Brothers, $692 \mathrm{p}$.

Myers, B.N., 1969, Compilation of results of aquifer tests in Texas: Texas Water Development Board Report 98, 537 p.

Ogilbee, William, Wesselman, J.B., and Irelan, Burdge, 1962, Geology and ground-water resources of Reeves County, Texas: Texas Water Commission Bulletin 6214, v. 1, 193 p.

Pavlicek, D.J., Small, T.A., and Rettman, P.L., 1987, Hydrogeologic data from a study of the freshwater zone/saline water zone interface in the Edwards aquifer, San Antonio region, Texas: U.S. Geological Survey Open-File Report 87-389, 108 p.

Pearson, F.J., Jr., and Rettman, P.L., 1976, Geochemical and isotopic analyses of waters associated with the Edwards Limestone aquifer, central Texas: Edwards Underground Water District Report, $35 \mathrm{p}$.

Perkins, B.F., 1974, Paleoecology of a rudist reef complex in the Comanche Cretaceous, Glen Rose Limestone, central Texas, in Perkins, B.F., ed., Aspects of Trinity division geology-a symposium: Louisiana State University, Geoscience and Man, v. 8, p. 131-173.

Petta, T.J., 1977, Diagenesis and geochemistry of a Glen Rose patch reef, Bandera County, Texas, in Bebout, D.G., and Loucks, R.G., eds., Cretaceous carbonates of Texas and Mexico, applications to subsurface exploration: Austin, University of Texas, Bureau of Economic Geology Report of Investigations 89, p. 138-167.

Puente, Celso, 1978, Method of estimating natural recharge to the Edwards aquifer in the San Antonio area, Texas: U.S. Geological Survey Water-Resources Investigations Report 78-10, $34 \mathrm{p}$.

Reaser, D.F., and Malott, V.E., 1985, Finlay Limestone-a key to geological interpretation in western Trans-Pecos Texas and northeastern Chihuahua, Mexico, in Dickerson, P.W., and Muehlberger, W.R., eds., Structure and tectonics of Trans-Pecos, Texas: West Texas Geological Society Field Conferences, Publication 85-81, p. 213-219.

Rees, Rhys, and Buckner, A.W., 1980, Occurrence and quality of ground water in the Edwards-Trinity (Plateau) aquifer in the Trans-Pecos region of Texas: Texas Department of Water Resources Report 255, $41 \mathrm{p}$.

Riggio, R.F., Bomar, G.W., and Larkin, T.J., 1987, Texas drought-its recent history (1931-1985): Texas Water Commission LP 87-04, $74 \mathrm{p}$.

Romanak, M.S., 1988, Sedimentology and depositional environment of the basement sand (Lower Cretaceous), west Texas: Arlington, Tex., University of Texas, unpub. M.S. thesis, $143 \mathrm{p}$.

Rose, P.R., 1972, Edwards Group, surface and subsurface, central Texas: Austin, University of Texas, Bureau of Economic Geology Report of Investigations 74, $198 \mathrm{p}$. 
Scott, R.W., and Kidson, E.J., 1977, Lower Cretaceous depositional systems, west Texas, in Bebout, D.G., and Loucks, R.G., eds., Cretaceous carbonates of Texas and Mexico, applications to subsurface exploration: Austin, University of Texas, Bureau of Economic Geology Report of Investigations 89, p. 169-181.

Sellards, E.H., 1933, The pre-Paleozoic and Paleozoic Systems in Texas, in The geology of Texas, v. I, Stratigraphy: Austin, University of Texas, Bureau of Economic Geology Bulletin 3232, p. 15-238.

1935, Structural geology of Texas east of Pecos River, in The geology of Texas, v. II, Structural and economic geology: Austin, University of Texas, Bureau of Economic Geology Bulletin 3401, p. 11-136.

Sharp, J.M., Jr., 1989, Regional ground-water systems in northern Trans-Pecos, Texas, in Structure and stratigraphy of Trans-Pecos, Texas-field trip guidebook T317, El Paso to Guadalupe Mountains and Big Bend, July 20-29, 1989: Washington, D.C., American Geophysical Union, p. 123-130.

Slade, R.M., Jr., Dorsey, M.E., and Stewart, S.L., 1986, Hydrology and water quality of the Edwards aquifer associated with Barton Springs in the Austin area, Texas: U.S. Geological Survey WaterResources Investigations Report 86-4036, $117 \mathrm{p}$.

Small, T.A., 1986, Hydrogeologic sections of the Edwards aquifer and its confining units in the San Antonio area, Texas: U.S. Geological Survey Water-Resources Investigations Report 85-4259, $52 \mathrm{p}$.

Small, T.A., and Ozuna, G.B., 1993, Ground-water conditions in Pecos County, Texas, 1987: U.S. Geological Survey Water-Resources Investigations Report 92-4190, 63 p.

Smith, C.I., 1970, Lower Cretaceous stratigraphy, northern Coahuila, Mexico: Austin, University of Texas, Bureau of Economic Geology Report of Investigations 65, $101 \mathrm{p}$.

1979, The Devils River trend and Maverick basin sequence, in Rose, P.R., ed., Stratigraphy of the Edwards Group and equivalents, eastern Edwards Plateau, Texas-guidebook for Gulf Coast Association of Geological Societies field trip 1, October 9-10, 1979: South Texas Geological Society, p. 14-18.

-1981, Review of the geologic setting, stratigraphy, and facies distribution of the Lower Cretaceous in northern Mexico, in Smith, C.I., and Brown, J.B., eds., Lower Cretaceous stratigraphy and structure, northern Mexico-field trip guidebook: West Texas Geological Society Publication 81-74, p. 1-27.

Smith, C.I., and Brown, J.B., 1983, Introduction to road log Cretaceous stratigraphy, in Kettenbrink, E.C., Jr., ed., Structure and stratigraphy of the Val Verde basin-Devils River uplift, Texas: West Texas Geological Society Publication 83-77, p. 1-47.

Stricklin, F.L., Jr., and Amsbury, D.L., 1974, Depositional environments on a low-relief carbonate shelf, Middle Glen Rose Limestone, central Texas, in Perkins, B.F., ed., Aspects of Trinity division geology-a symposium: Louisiana State University, Geoscience and Man, v. 8, p. 53-66.

Stricklin, F.L., Jr., and Smith, C.I., 1973, Environmental reconstruction of a carbonate beach complex, Cow Creek (Lower Cretaceous) Formation of Central Texas: Geological Society of America Bulletin, v. 84 , no. 4 , p. 1,349-1,367.

Stricklin, F.L., Jr., Smith, C.I., and Lozo, F.E., 1971, Stratigraphy of Lower Cretaceous Trinity deposits of central Texas: Austin, University of Texas, Bureau of Economic Geology Report of Investigations $71,63 \mathrm{p}$.

Taff, J.A., 1892, Reports on the Cretaceous area north of the Colorado River: Texas Geological Survey, 3d Annual Report (1891), p. 267-379.

Texas Department of Health, 1977, Drinking water standards governing drinking water quality and reporting requirements for public water systems (revised 1990): Austin, Division of Water Hygiene, $34 \mathrm{p}$.
Texas Water Development Board, 1990, Water for Texas, today and tomorrow: Texas Water Development Board Document No. GP-5-1, $186 \mathrm{p}$.

Theis, C.V., 1935, The relation between the lowering of the piezometric surface and rate and duration of discharge of a well using ground-water storage: American Geophysical Union Transactions, v. 16, p. 519-524.

University of Texas, Bureau of Economic Geology, 1974a, Geologic atlas of Texas, Austin sheet: Austin, scale 1:250,000.

$-1974 \mathrm{~b}$, Geologic atlas of Texas, Big Spring sheet: Austin, scale 1:250,000.

1975, Geologic atlas of Texas, San Angelo sheet: Austin, scale 1:250,000.

1976a, Geologic atlas of Texas, Brownwood sheet: Austin, scale 1:250,000.

1976b, Geologic atlas of Texas, Pecos sheet: Austin, scale 1:250,000.

1976c, Geologic atlas of Texas, Hobbs sheet: Austin, scale 1:250,000.

1977, Geologic atlas of Texas, Del Rio sheet: Austin, scale 1:250,000.

1981a, Geologic atlas of Texas, Llano sheet: Austin, scale 1:250,000.

$-1981 \mathrm{~b}$, Geologic atlas of Texas, Sonora sheet: Austin, scale 1:250,000.

1983, Geologic atlas of Texas, San Antonio sheet: Austin, scale 1:250,000.

van der Leeden, Frits, Troise, F.L., and Todd, D.K., 1990, The water encyclopedia: Chelsea, Mich., Lewis Publishers, Inc., p. 808.

Veni, George, 1994, Geomorphology, hydrology, geochemistry, and evolution of the karstic Lower Glen Rose aquifer, south-central Texas: Pennsylvania State University, Ph.D. dissertation, 712 p.

Walker, L.E., 1979, Occurrence, availability, and chemical quality of ground water in the Edwards Plateau Region of Texas: Texas Department of Water Resources Report 235, 336 p.

Walper, J.L., and Miller, R.E., 1985, Tectonic evolution of Gulf Coast basin, in Fourth Annual Research Conference, June 1985, Proceedings: Gulf Coast Society of Economic Paleontologists and Mineralogists Foundation, p. 25-41.

Waters, J.A., McFarland, P.W., and Lea, J.W., 1955, Geologic framework of the Gulf Coastal Plain of Texas: American Association of Petroleum Geologists Bulletin, v. 39, no. 9, p. 1,821-1,850.

Webster, R.E., 1980, Structural analysis of Devils River upliftsouthern Val Verde basin, southwest Texas: American Association of Petroleum Geologists Bulletin, v. 64, no. 2, p. 221-241.

Weeks, A.W., 1945, Balcones, Luling, and Mexia fault zones in Texas: American Association of Petroleum Geologists Bulletin, v. 29, no. 12 , p. 1,733-1,737.

Weeks, J.B., Gutentag, E.D., Heimes, F.J., and Luckey, R.R., 1988, Summary of the High Plains Regional Aquifer-System Analysis in parts of Colorado, Kansas, Nebraska, New Mexico, Oklahoma, South Dakota, Texas, and Wyoming: U.S. Geological Survey Professional Paper 1400-A, $30 \mathrm{p}$.

Weeks, J.B., and Sun, R.J., 1987, Regional Aquifer-System Analysis Program of the U.S. Geological Survey-bibliography, 1978-86: U.S. Geological Survey Water-Resources Investigations Report $87-4138,81 \mathrm{p}$.

Welder, F.A., and Reeves, R.D., 1964, Geology and ground-water resources of Uvalde County, Texas: U.S. Geological Survey Water-Supply Paper 1584, $50 \mathrm{p}$.

Wermund, E.G., and Woodruff, C.M., Jr., 1977, Land resource units for planning in carbonate terranes, in Tolson, J.S., and Doyle, F.L., eds., International Association of Hydrogeologists Memoirs: Huntsville, Ala., University of Alabama in Huntsville Press, v. 12 , p. $339-353$. 
Wessel, G.R., 1988, Shallow stratigraphy, structure, and salt-related features, Yates oil field area, Pecos and Crockett Counties, Texas: Golden, Colo., Colorado School of Mines, unpub. Ph.D. dissertation, $144 \mathrm{p}$.

White, W.N., Gale, H.S., and Nye, S.S., 1941, Geology and groundwater resources of the Balmorhea area, western Texas: U.S. Geological Survey Water-Supply Paper 849-C, p. 83-146.

Wilhelm, O., and Ewing, M., 1972, Geology and history of the Gulf of Mexico: Geological Society of America Bulletin, v. 85, no. 3, p. 575-600.

Winter, J.A., 1962, Fredericksburg and Washita strata (subsurface Lower Cretaceous), southwest Texas, in Contributions to the geology of south Texas: San Antonio, South Texas Geological Society, p. 81-115.

Wood, M.L., and Walper, J.L., 1974, The evolution of the interior Mesozoic basin and the Gulf of Mexico: Transactions of the Gulf Coast Association Geological Societies, v. 24, p. 31-41.

Woodruff, C.M., Jr., and Abbott, P.L., 1986, Stream piracy and evolution of the Edwards aquifer along the Balcones escarpment, central Texas, in Abbott, P.L., and Woodruff, C.M., Jr., eds., The Baicones escarpment, geology, hydrology, ecology and social development in central Texas: Geological Society of America, p. 77-99. 





\section{Selected Series of U.S. Geological Survey Publications}

\section{Periodicals}

Earthquakes \& Volcanoes (issued bimonthly).

Preliminary Determination of Epicenters (issued monthly).

\section{Technical Books and Reports}

Professional Papers are mainly comprehensive scientific reports of wide and lasting interest and importance to professional scientists and engineers. Included are reports on the results of resource studies and of topographic, hydrologic, and geologic investigations. They also include collections of related papers addressing different aspects of a single scientific topic.

Bulletins contain significant datti and interpretations that are of lasting scientific interest but are generally more limited in scope or geographic coverage than Professional Papers. They include the results of resource studres and of geologic and topographic investigations. as well as collections of short papers related to a specific topic.

Water-Supply Papers are comprehensive reports that present significant interpretive results of hydrologic investigations of wide interest to professional geologists, hydrologists. and engineers. The series eovers investigations in all phases of hydrology, including hydrogeology. arailability of water. quality of water, and use of water

Circulars present administrative information or important scientific information of wide popular interest in a format designed for distribution at no cost to the public. Information is usually of short-term interest.

Water-Resources Investigations Reports are papers of an interpretive nature made available to the public outside the formal USGS publications series. Copies are reproduced on request unlike formal USGS publications, and they are also available for public inspection at depositories indicated in USGS catalogs.

Open-File Reports include unpublished manuscript reports. maps, and other material that are made available for public consultation at depositories. They are at nonpermanent form of publication that may be eited in other publications as sources of information.

\section{Maps}

Geologic Quadrangle Maps are multicolor geologic maps on topographic bases in 7.5- or 15-minute quadrangle formats (scales mainly 1:24.000 or 1:62.500) showing bedrock, surficial, or engineering geology. Maps generally include brief texts: some maps include structure and columnar sections only.

Geophysical Investigations Maps are on topographic or planimetric bases at various scales: they show results of surveys using geophysical techniques, such as gravity. magnetic, seismic, or radioactivity, which reflect subsurface structures that are of economic or geologic significance. Many maps include correlations with the geology.

Miscellaneous Investigations Series Maps are on planimetric or topographic bases of regular and irregular areas at various scales: they present a wide variety of format and subject matter. The series also includes 7.5-minute quadrangle photogeologic maps on planimetric bases that show geology as interpreted from aerial photographs. Series also includes maps of Mars and the Moon.
Cost Investigations Maps are geologic maps on topographic or planimetric bases at various scales show ing bedrock or surficial geology, stratigraphy, and structural relations in certain coalresource areas.

Oil and Gas Investigations Charts show stratigraphic information for certain oil and gas fields and other areas having petroleum potential.

Miscellaneous Field Studies Maps are multicolor or blackand-white maps on topographic or planimetric bases for quadrangle or irregular areas at various scales. Pre-1971 maps show bedrock geology in relation to specific mining or mineral-deposit problems: post-1971 maps are primarily black-and-white maps on various subjects such as environmental studies or wilderness mineral investigations.

Hydrologic Investigations Atlases are multicolored or black-and-white maps on topographic or planimetric bases presenting a wide range of geohydrologic data of both regular and irregular areas; principal scale is 1:24,000, and regional studies are at 1:250,000 scale or smaller.

\section{Catalogs}

Permanent catalogs, as well as some others, giving comprehensive listings of U.S. Geological Survey publications are available under the conditions indicated below from the U.S. Geolngical Survey, Information Services, Box 25286. Federal Center. Denver, CO 80225. (See latest Price and Availability List.)

"Publications of the Geological Survey, 1879-1961" may be purchased by mail and over the counter in paperback book form and as a set of nicrofiche.

"Publications of the Geological Survey, 1962-1970" may be purchased by mail and over the counter in paperback book form and as a set of microfiche.

"Publications of the U.S. Geological Survey, 1971-1981" may he purchased by mail and over the counter in paperbach book form (two volumes. publications listing and index) and as a set of microfiche

Supplements for 1982. 1983, 1984, 1985, 1986, and for subsequent years since the last permanent catalog may he purchased by mail and over the counter in paperback book form.

State catalogs, "List of U.S. Geological Survey Geologic and Water-Supply Reports and Maps For (State)," may he purchased by mail and over the counter in paperback boohlet form only.

"Price and Availability List of U.S. Geological Survey Publications," issued annually, is available free of charge in paperback booklet form only.

Selected copies of a monthly catalog "New Publications of the U.S. Geological Survey" are available free of charge by mail or may be obtained over the counter in paperback hooklet form only. Those wishing a free subscription to the monthly catalog "New Publications of the U.S. Geological Survey" should write to the U.S. Geological Survey, 582 National Center, Reston, VA 20192.

Note.--Prices of Government publications listed in older catalogs, announcements, and publications may be incorrect. Therefore, the prices charged may differ from the prices in catalogs, announcements, and publications. 
